Estudo de tecnologias aplicadas à educação a distância

\author{
Lílian Simão Oliveira
}



SERVIÇO DE PÓS-GRADUAÇÃO DO ICMC-USP

Data de Depósito:

Assinatura:

\title{
Estudo de tecnologias aplicadas à educação a distância
}

\author{
Lílian Simão Oliveira
}

Orientadora: Profa. Dra. Maria Graça Pimentel

Dissertação apresentada ao Instituto de Ciências Matemáticas e de Computação - ICMC-USP, como parte dos requisitos para obtenção do título de Mestre em Ciências - Ciências de Computação e Matemática Computacional. VERSÃO REVISADA.

USP - São Carlos

Junho/2011 
Ficha catalográfica elaborada pela Biblioteca Prof. Achille Bassi e Seção Técnica de Informática, ICMC/USP, com os dados fornecidos pelo(a) autor(a)

Simão Oliveira, Lílian

Estudo de tecnologias aplicadas à educação a

distância / Lílian Simão Oliveira; orientadora Maria da Graça Campos Pimentel -- São Carlos, 2011.

$137 \mathrm{p}$.

Dissertação (Mestrado - Programa de Pós-Graduação en Ciências de Computação e Matemática Computacional) -Instituto de Ciências Matemáticas e de Computação, Universidade de São Paulo, 2011.

1. Educação a distância. 2. TV Digital. 3. LMS. I. Campos Pimentel, Maria da Graça, orient. II. Título. 
"A genialidade é $2 \%$ de inspiração e 98\% de transpiração. "

Thomas Edson 


\section{Resumo}

A educação a distância é uma realidade bem vista por muitas instituições de ensino e pelo Ministério da Educação, sendo, portanto, fortemente incentivada. Essa modalidade vai muito além da alternativa de oferecer cursos de maneira confortável para alunos que não têm disponibilidade de tempo em horário comercial. Em alguns casos, esse é o único meio de atingir uma parcela da população que, apesar de encontrar-se isolada geograficamente, tem direito à educação básica de qualidade e gratuita como forma de garantir os seus direitos de cidadão. Este trabalho teve como objetivo investigar alternativas de software que visam oferecer apoio para a oferta de cursos na modalidade a distância. Como estudo de caso, foi delimitado um cenário real: o do estado do Amazonas, que conta com diversos esforços bem sucedidos no uso de educação a distância como alternativas para reduzir o isolamento geográfico. Para auxiliar os alunos e professores foi escolhido o ambiente Tidia-Ae, sendo que o maior enfoque foi dado à ferramenta DigaE e suas extensões, por possibilitarem a autoria de documentos multimídia interativos.

Palavras-chave: Educação a distância, TV Digital, LMS 


\section{Abstract}

Distance education is a education model that was recommend by many educational institutions and by the Education Ministry. This model goes beyond of offering courses in a comfortable way for students who do not have time available during business hours. In some cases, this is the only way to offer for a population that, although is geographically isolated, has the right to quality basic education and free as a way to guarantee their rights as citizens. This study aimed to investigate alternatives to the use of software tools aimed at providing support for the provision of courses in the distance. As a particular case, was delimited a real scenario: the Amazon state, which has several successful efforts in using distance education as alternatives to reduce the geographic isolation. To assist students and teachers were chosen environment Tidia-Ae, with the main focus was given to the DigaE tool and its extensions, for making possible the interactive multimedia document authoring.

key-words: Distance Education, Digital TV, LMS 


\section{Sumário}

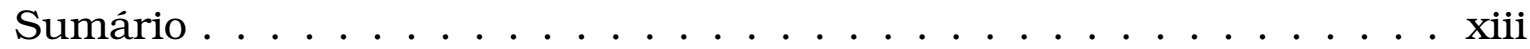

Lista de Figuras . . . . . . . . . . . . . . . xv

Lista de Tabelas . . . . . . . . . . . . . . . . xvii

1 Introdução 1

1.1 Contexto e Motivação . . . . . . . . . . . . . . . . . 1

1.2 Problema ..................... 3

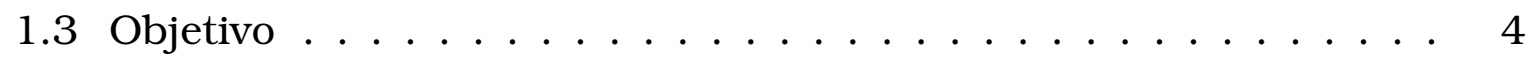

1.4 Etapas de desenvolvimento . . . . . . . . . . . . . . 4

1.5 Contribuições do projeto $\ldots \ldots \ldots \ldots \ldots \ldots$

1.6 Organização da dissertação . . . . . . . . . . . . . . . 5 5

2 Contexto de EaD $\quad 7$

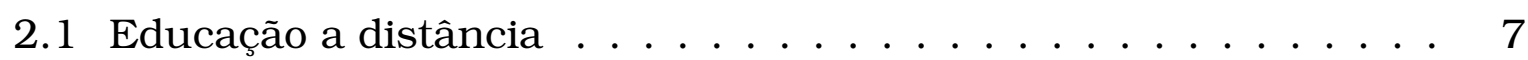

2.1 .1 Caracterização de $\mathrm{EaD} \ldots \ldots \ldots \ldots$

2.2 Learning Management System (LMS) . . . . . . . . . . . . . . 13

2.2 .1 TelEduc . . . . . . . . . . . . . . . . 13

2.2 .2 Moodle . . . . . . . . . . . . . . . . . . . . 14

2.2 .3 Tidia-Ae . . . . . . . . . . . . . . . . . 14

2.3 Ferramentas de software disponibilizadas em LMS . . . . . . . 15

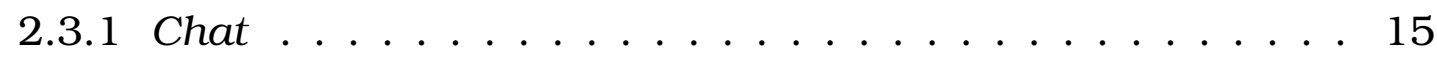

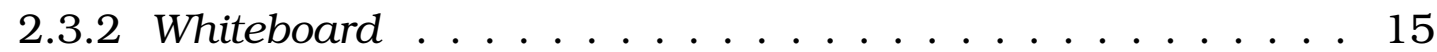

2.3 .3 Fórum . . . . . . . . . . . . . . . . 16

2.3 .4 Vídeoconferência . . . . . . . . . . . . . . . 16

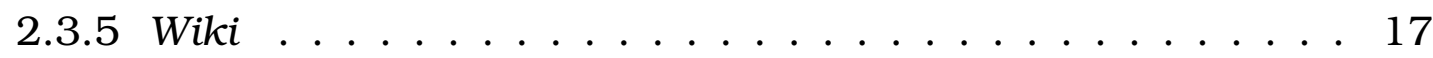

2.4 TV Digital . . . . . . . . . . . . . . . . . 17

2.4 .1 Considerações Finais $\ldots \ldots \ldots \ldots$

3 Projetos desenvolvidos no estado do Amazonas 21

3.1 Considerações sobre o estado do Amazonas . . . . . . . . . . 21 
3.1 .1 Educação no Amazonas . . . . . . . . . . . . . . . . . . . 22

3.2 Cursos de EaD no AM . . . . . . . . . . . . . . . 25

3.2.1 Universidade Federal do Amazonas (UFAM) . . . . . . 25

3.2.2 Universidade do Estado do Amazonas (UEA) . . . . . . . . . 26

3.2.3 Centro de Educação Tecnológica do Amazonas (CETAM) . . 28

3.2.4 Colégio Militar de Manaus (CMM) _ . . . . . . . . 29

3.2.5 Secretaria da Educação do estado do Amazonas . . . . . . 30

3.2.6 Instituto Federal do Amazonas (IFAM) . . . . . . . . . 32

3.2 .7 Considerações sobre os projetos . . . . . . . . . . . 34

3.3 Escolha do projeto para estudo de caso . . . . . . . . 36

3.4 Relatos . . . . . . . . . . . . . . . . 36

3.5 Considerações Finais . . . . . . . . . . . . . . . . . . 39

4 EaD e TV $\quad 41$

4.1 EaD e padrões de conteúdo . . . . . . . . . . . . 41

4.2 A TV e a educação . . . . . . . . . . . . . . . 43

4.3 A TVDi e a educação . . . . . . . . . . . . . . . . . . 44

4.4 Focos de desenvolvimento em t-learning . . . . . . . . . . 45

4.5 Produção de Conteúdo para t-learning . . . . . . . . . . . . . 47

4.6 t-learning e a usabilidade . . . . . . . . . . . . . 49

4.7 Casos de Uso do t-learning . . . . . . . . . . . . . . 50

4.8 Considerações Finais . . . . . . . . . . . . . . . 52

5 Estudo de aplicação do Tidia-Ae no IFAM 55

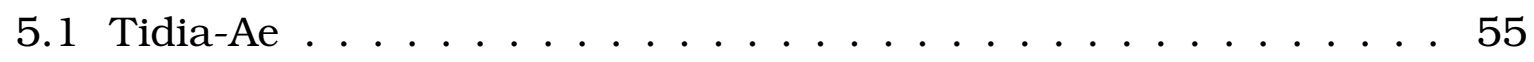

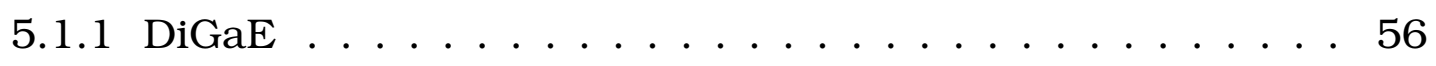

5.1 .2 DiGaE-TV . . . . . . . . . . . . . . 59

5.2 Cenário do Estudo de Caso . . . . . . . . . . . . . . 63

5.3 Considerações Finais . . . . . . . . . . . . . . 67

6 Experiências obtidas no estudo $\quad 69$

6.1 Experiência dos alunos de Eirunepé $\ldots \ldots \ldots \ldots \ldots$

6.2 Teste de Usabilidade: Ferramenta DigaE . . . . . . . . . . . . . 72

6.3 Teste de sincronismo entre servidores Tidia-Ae . . . . . . . . 76

6.4 Avaliação Heurística . . . . . . . . . . . . . . . . . . . 79

6.5 Considerações Finais . . . . . . . . . . . . . . . . . . 89

7 Conclusão $\quad 91$

7.1 Contribuições e limitações do projeto . . . . . . . . . . 93

7.2 Trabalhos Futuros . . . . . . . . . . . . . . . . 94

$\begin{array}{ll}\text { Referências } & 105\end{array}$ 
A Documentos utilizados nas avaliações 


\section{Lista de Figuras}

2.1 As gerações do $\mathrm{EaD} \ldots \ldots \ldots \ldots$

2.2 Middleware Ginga $\ldots \ldots \ldots \ldots \ldots$

2.3 Protocolos Ginga . . . . . . . . . . . . . . . . . . . . . . 19

3.1 Bacia hidrográfica do estado do Amazonas . . . . . . . . . . . . 22

3.2 Estadas do estado do Amazonas . . . . . . . . . . . . . . . . . 24

3.3 CMM no Brasil . . . . . . . . . . . . . . . . . . . . . . . 29

3.4 CMM no mundo . . . . . . . . . . . . . . 30

3.5 Estrutura de EaD no IFAM . . . . . . . . . . . . . . . . 32

3.6 IFAM - Materiais Didáticos . . . . . . . . . . . . . . . 33

3.7 IFAM - Aulas . . . . . . . . . . . . . . . . 34

3.8 IFAM - Avaliação . . . . . . . . . . . . . . . . . 35

5.1 Tidia-Ae . . . . . . . . . . . . . . . 56

5.2 Relação DiGaE e Tidia-Ae . . . . . . . . . . . . . . . . . . 57

5.3 Ferramenta DiGaE . . . . . . . . . . . . . . . 58

5.4 Sessão DiGaE . . . . . . . . . . . . . . . . . . . . . . . 59

5.5 DiGaE-TV . . . . . . . . . . . . . . . . 60

5.6 Menu do DiGaE-TV . . . . . . . . . . . . . . . 61

5.7 Exemplo do DiGaE-TV . . . . . . . . . . . . . . . 62

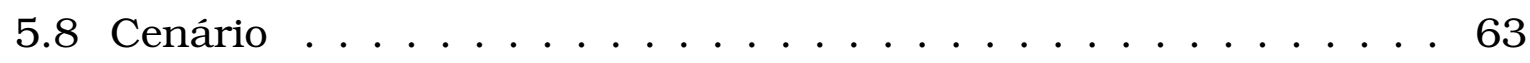

$5.9 \mathrm{DiGaE}$ - SMIL no Firefox . . . . . . . . . . . . . . . 64

$5.10 \mathrm{DiGaE}$ - SMIL no RealPLayer . . . . . . . . . . . . 65

6.1 Gráfico Taxa de Transferêcia . . . . . . . . . . . . . . 76

6.2 DigaE . . . . . . . . . . . . . . . . . 85

6.3 DigaE depois das avaliações $\ldots \ldots \ldots \ldots$ 


\section{Lista de Tabelas}

2.1 Tecnologias utilizadas em EaD . . . . . . . . . . . . 12

3.1 PIB do estado do Amazonas . . . . . . . . . . . . . 23

3.2 Resultado do ENEM referente ao Amazonas . . . . . . . . . . . 23

3.3 ENADE 2008 referente ao Amazonas . . . . . . . . . . . . . . 25

3.4 Vantagens e Desvantagens de EaD no AM . . . . . . . . . 35 


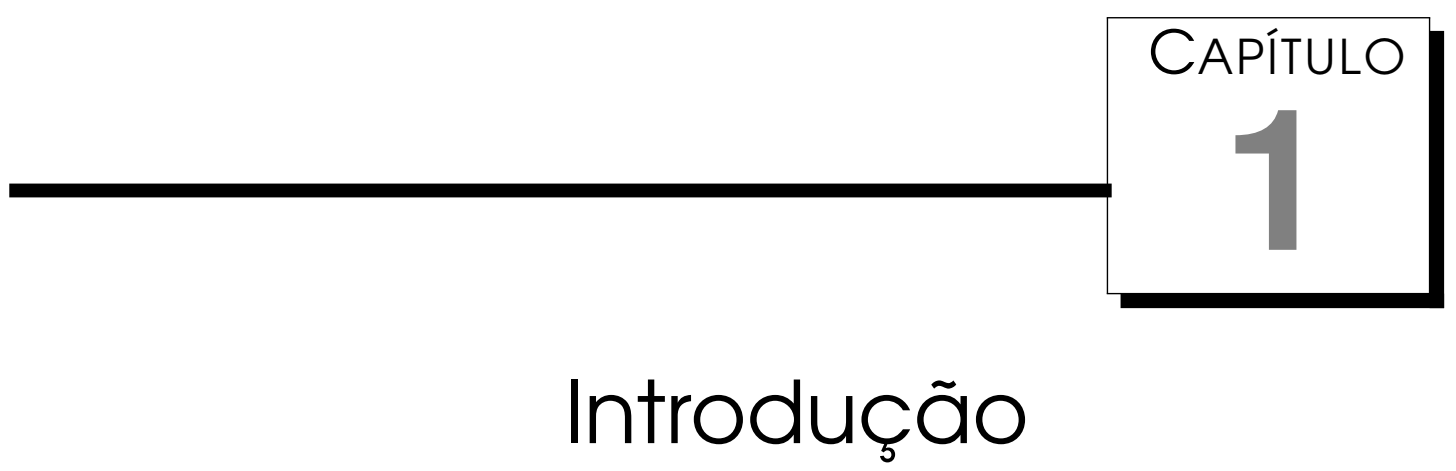

\subsection{Contexto e Motivação}

A educação a distância (EaD), ao longo dos anos, vem ganhando espaço e credibilidade. Por meio desse modelo, é possível oferecer uma educação de qualidade e aproximar pessoas que não residem, por exemplo, nos grandes centros metropolitanos.

A introdução dos recursos de informática tem tornado mais eficiente a modalidade de EaD. A utilização de redes de computadores, os recursos de multimídia e a Internet como mediadores da comunicação entre alunos e professores têm aumentado a interação entre indivíduos. É importante observar que a educação a distância não deve ser vista como uma substituição da educação formal, presencial, convencional e, sim, como uma alternativa. A EaD não concorre com a educação convencional: são duas modalidades do mesmo processo.

Em uma realidade em que a educação a distância surge como possibilidade para garantir um dos direitos básicos do cidadão, que é a educação, faz-se necessário garantir a qualidade desse processo. Este trabalho tem como meta estudar a aplicação de recursos computacionais empregados em cursos a distância na realidade do estado do Amazonas. Esse cenário permitiu obter dados concretos que podem servir de recomendações em situações de isolamento geográfico similares.

O estado do Amazonas possui vasta extensão territorial e é cortado por diversos rios, o que faz com que algumas regiões fiquem isoladas. Com isso, o problema da educação nas cidades do interior do estado merece uma atenção 
especial, pois as dificuldades são inúmeras, tais como: déficit de professores qualificados dispostos a residir em cidades que se encontram muito afastadas da capital do estado; má infraestrutura; difícil acesso para a maioria das cidades.

Simões et al. (2004) cita algumas limitações da educação na Amazônia: "Dentre os traços característicos afins nessas comunidades da região Amazônica, observamos, por exemplo, que inexiste saneamento básico; água tratada; unidades de saúde; energia elétrica (a energia quando existe, é transmitida por meio de geradores a óleo ou à bateria). (...) O transporte, quando existe, é a bicicleta, raramente a moto, a montaria e o barco. A habitação também é precária; a educação escolar, quando existe, vai da $1^{\text {a }}$ a $4^{\text {a }}$ série somente, realizada, por meio das escolas multisseriadas."

Desde 2007 foram desenvolvidos inúmeros projetos bem sucedidos que levam educação à população ribeirinha e interiorana. A Secretaria de Ensino do Estado (SEDUC-AM), por exemplo, tem inovado na área de educação a distância voltada ao ensino médio e fundamental ${ }^{1}$ com o uso de tecnologias mais recentes e abrangentes. Tal projeto utiliza a tecnologia de TV Digital por meio de satélite que permite a interação completa entre o estúdio que transmite as aulas ao vivo e os alunos que participam por meio de chat, e-mail e/ou videoconferência.

No caso do ensino de nível superior, existem alguns projetos como o Proformar, desenvolvido pela Universidade do Estado do Amazonas (UEA), que ofereceu o curso de Normal Superior de 2002 até 2008. Outro projeto relacionado é o projeto TATIS (Tecnologia em Análise e Desenvolvimento de Sistema), oferecido pela mesma instituição, por meio do qual são ministrados cursos de nível superior na área de informática. Em ambos os projetos, as aulas são gravadas em um estúdio e transmitidas ao vivo para todo os 62 municípios do estado. Dúvidas de alunos, que surgiam durante as aulas, eram encaminhadas por e-mail, telefone ou fax para uma equipe de apoio presente no estúdio. Uma vez recebidas, as dúvidas eram filtradas, e as selecionadas eram solucionadas no decorrer do programa ao vivo; as demais eram resolvidas de acordo com a prioridade estabelecida pela equipe de apoio.

Desde 2010, um projeto realizado pelo Instituto Federal do Amazonas (IFAM) oferece ensino técnico profissionalizante a distância em Turismo e em Meio Ambiente em cinco municípios do estado do Amazonas: Tefé, Eurunepé, Tabatinga, Barrerinha e Manaus. ${ }^{2}$ Esse projeto utiliza uma plataforma LMS (Learning Management System) para ministrar o conteúdo dos cursos. O software escolhido foi o LMS Moddle, uma ferramenta de software livre, homologada pelo MEC e amplamente utilizada por cursos de educação a distância e

\footnotetext{
${ }^{1}$ http://www.seduc.am.gov.br/noticia.php?cod=593

${ }^{2}$ http://ead.ifam.edu.br/
} 
também como suporte ao ensino presencial.

Por meio desses exemplos nota-se que a educação a distância surge como uma alternativa importante para regiões de difícil acesso no estado do Amazonas. Essa alternativa é descrita na Lei de Diretrizes e Bases (LDB) 9.394/1996, artigo 80, em que está previsto o aceite e o incentivo do Poder Público para o desenvolvimento e a veiculação de programas de educação a distância, em todos os níveis e modalidades de ensino incluindo a educação continuada.

Além da educação a distância ser uma modalidade de ensino que pode atender as necessidades da região, faz-se necessária uma ferramenta que controle as respostas dadas aos alunos que apresentaram dúvidas e sugestões. Essa necessidade é apresentada pelo Ministério de Educação (MEC) na Lei de Diretrizes e Bases da Educação, do Decreto 5.622, de 20 de dezembro de 2005, do Decreto 5.773, de junho de 2006 e das Portarias Normativas 1 e 2, de 11 de janeiro de 2007. Tal demanda foi apontada, também, pelo presidente da ABE-EaD (Associação Brasileira dos Estudantes de Educação a Distância), Ricardo Holz em entrevista: ${ }^{3}$ "Há muitas denúncias de problemas relacionados à comunicação entre alunos e instituições. Não por falta de canais, mas sim pela ausência de retorno ou pela demora das respostas. Prazos que geralmente chegam a extrapolar 60 dias". Ainda nesse contexto, Ladim e Ribeiro (2000) afirma: "É importante, também, mencionar que muitas são as dificuldades para o desenvolvimento de cursos de EaD. Uma delas é a demora no atendimento, por alguns tutores, às solicitações dos alunos e/ou retorno das avaliações, o que gera desestímulo e, muitas vezes, abandono do curso". Ou seja, é importante que os alunos contem com estímulos e meios para desempenhar um papel ativo e participativo no processo de ensino-aprendizagem. É fundamental, por exemplo, uma resposta rápida às dúvidas formuladas.

\subsection{Problema}

A educação distância é uma modalidade que exige do aluno muita organização e pró-atividade. Também é necessário que as instituições que oferecem cursos nessa modalidade tenham a preocupação com o material produzido, para que seja bom o suficiente para o aluno compreender e assimilar os novos conteúdos que serão transmitidos. Algumas ferramentas de software baseadas na Internet têm, ao longo dos anos, oferecido recursos para aproximar alunos e professores, com o objetivo de contribuirem para que dúvidas decorrentes do processo de aprendizagem sejam discutidas e, eventualmente, sanadas. Porém, nem todos os lugares possuem Internet em qualidade apropriada para atender os requisitos mínimos dessas ferramentas - com isso, alunos ficam

\footnotetext{
${ }^{3}$ Disponível em: http://www.universia.com.br/ead/materia.jsp?materia=16680
} 
restritos a apostilas impressas, CDs com conteúdos multimídias, e ao uso esporádico do ambiente virtual. Essa realidade é comum no estado do Amazonas onde a qualidade da Internet, que é um problema na capital, se agrava ainda mais nos demais municípios.

\subsection{Objetivo}

O objetivo do trabalho proposto nesta monografia é investigar ferramentas que auxiliem a comunicação entre alunos e professores de cursos na modalidade de educação a distância em áreas com restrições de Internet. Explorando tecnologias Web e de TV Digital, como estudo de caso foram pesquisadas alternativas que levam em consideração particularidades do estado do Amazonas, como o seu isolamento geográfico e pouca disponibilidade de Internet.

\subsection{Etapas de desenvolvimento}

As etapas de desenvolvimento deste trabalho foram em:

1. Pesquisa bibliográfica: nessa fase foi realizado o levantamento de trabalhos relacionados a educação a distância no estado do Amazonas, a TV Digital interativa (TVDi) e ao ambiente Tidia-Ae. A pesquisa bibliográfica foi realizada com artigos, livros, revistas e na Web, com o intuito de obter informações que contribuíssem para o desenvolvimento de uma solução viável e de bom aproveitamento pelos alunos dos curso de EaD;

\section{Levantamento de projetos atualmente em andamento no estado do}

Amazonas: nessa fase foram identificados aspectos positivos e outros que poderiam ser melhorados, a fim de obter os requisitos e os principais problemas a serem abordados e solucionados;

3. Análise da plataforma: nessa fase foi realizada uma análise das plataformas Tidia-Ae e SBTVD, para definir o cenário a ser utilizado, delimitando, assim, o escopo do trabalho;

4. Estudo de Caso: nessa fase foi realizado um estudo das ferramentas disponibilizadas por meio do LMS Tidia-Ae as quais poderiam contribuir para a melhoria da educação a distância. Também foram realizadas algumas modificações nos ambientes já desenvolvidos a fim de adequá-los às restrições impostas pela realidade da educação no estado do Amazonas;

5. Avaliação da usabilidade do sistema: nessa fase foi realizado avaliação de usabilidade tanto com o público-alvo quanto com especialistas; 
6. Análise dos resultados: nessa fase foi realizada uma análise de todos os dados coletados a partir dos testes e entrevistas com os envolvidos nas avaliações.

\subsection{Contribuições do projeto}

De forma geral, o presente trabalho apresenta três contribuições:

- Como primeira contribuição, é detalhado o estudo que apresenta o uso da TVDi como ferramenta de apoio à educação a distância.

- Como segunda contribuição, é proposto o uso, por um professor, de uma ferramenta de software open source que possibilita a criação de vídeoaula de forma fácil e intuitiva, e que faz com que os custos de preparação da aula sejam reduzidos quando comparados com esforços que exigem estúdios profissionais.

- Como terceira contribuição, o trabalho expõe necessidades de envolvidos em um curso a distância e discute o uso, por parte de alunos, de uma ferramenta que proporciona diversos meios de comunicação e de acesso a conteúdos multimídia.

\subsection{Organização da dissertação}

Esta dissertação está organizada do seguinte modo:

Capítulo 2 - Fundamentação Teórica - são apresentados os conceitos fundamentais que foram utilizados para o desenvolvimento deste projeto: Educação a distância: discute os principais conceitos relacionados e as características que serão consideradas no decorrer do trabalho; Tecnologias utilizadas em EaD: relacionam algumas plataformas de apoio e as principais ferramentas que são utilizadas nessa modalidade; considerações sobre o estado do Amazonas: discorre sobre as dificuldades em relação ao ensino no estado e o porquê da grande importância da educação a distância para superar esses impedimentos;

Capítulo 3 - Projetos desenvolvidos no estado do Amazonas - é apresentado um levantamento sobre os projetos desenvolvidos no estado do Amazonas que fazem uso de educação a distância;

Capítulo 4 - Trabalhos relacionados - é apresentado um levantamento bibliográfico sobre padrões de conteúdo educacional, uso de TV Digital na educação, produção de conteúdo e usabilidade, entre outros; 
Capítulo 5 - Estudo de aplicação do Tidia-Ae no IFAM - é apresentado as ferramentas que foram utilizadas neste trabalho e a descrição no cenário que foi realizado o estudo;

Capítulo 6 - Experiências obtidas no estudo- apresenta os testes realizados para verificar a aplicabilidade das ferramentas estudadas em um ambiente real de ensino a distância. Foram realizados testes com alunos e especialistas em interação humano-computador. Também foram realizadas entrevistas com pessoas envolvidas nesse processo de aprendizagem, como o professor e o coordenador do núcleo de ensino a distância do IFAM;

Capítulo 7 - Conclusões - nesse Capítulo são apresentadas: as contribuições deste trabalho, as discursões levantadas, as limitações observadas e os trabalhos futuros. 


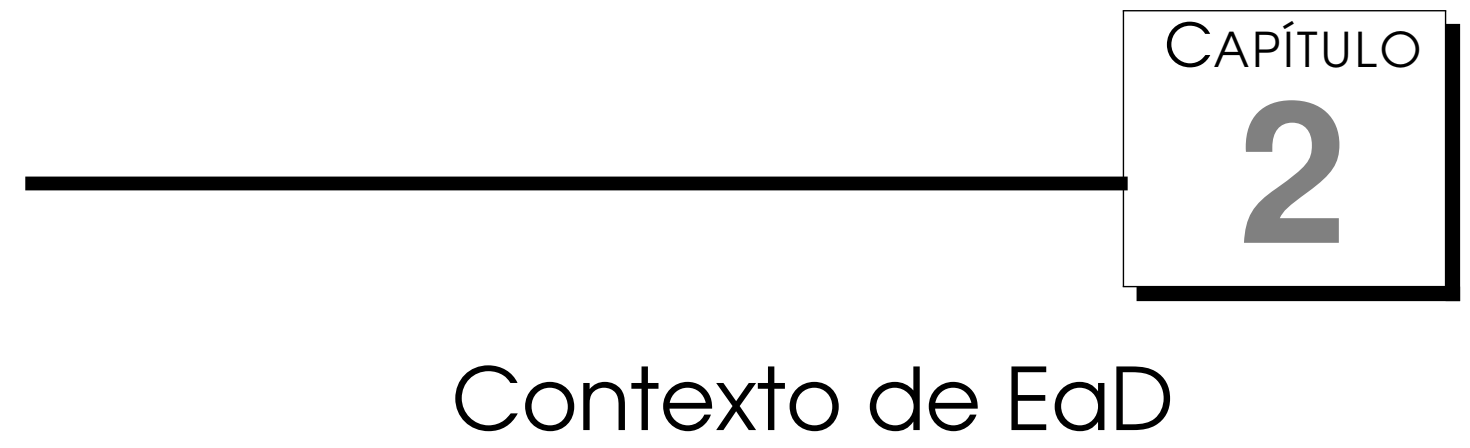

Neste Capítulo são apresentadas informações importantes para o entendimento do trabalho relatado nesta dissertação: educação a distância, Learning Managemment System LMS, ferramentas de softwares utilizadas em ambientes virtuais de EaD, TV Digital e considerações sobre o estado do Amazonas. Essas informações tem como objetivo situar o leitor no cenário em que foi realizado este trabalho .

\subsection{Educação a distância}

A educação a distância acontece quando o aluno não está junto do professor em uma instituição de ensino, presencialmente, participando das atividades e interagindo com seus colegas de classe. Isso pode acontecer por diversos motivos, tais como: restrições geográficas, falta de tempo para comparecer às instituições de ensino que oferecem cursos presenciais, comodidade de aprender algo novo em seu local de trabalho ou em sua residência, etc.

Uma definição formal, segundo Moore e Kearley (2008), para esse tipo de ensino é: "Educação a distância é o aprendizado planejado que ocorre normalmente em um lugar diferente do local de ensino, exigindo técnicas especiais de criação do curso e de instrução, comunicação por meio de várias tecnologias e disposições organizacionais e administrativas especiais".

Para descrever a prática de aprender algum ofício ou disciplina a distância são usados alguns termos. Sendo assim, a fim de esclarecer e utilizar uma única terminologia no decorrer do trabalho, foram conceituados alguns termos:

Moore e Kearley (2008) comenta que quando relacionamos aprendizado e 
ensino é preciso usar o termo "educação". Neste trabalho será usado o termo educação com a finalidade de descrever a aprendizagem intencional, uma aprendizagem planejada e pela qual uma pessoa, o aluno, se propõe a aprender e é auxiliado por outra, o professor ou tutor, que cria, intencionalmente, meios para ajudar essa pessoa a aprender.

\subsubsection{Caracterização de EaD}

Diversos cursos são oferecidos a distância, para saber diferenciá-los vamos utilizar alguns parâmetros de classificação. Segundo Trindade (1997), as instituições que desenvolvem essa modalidade de educação variam de acordo com os objetivos das estruturas educacionais, seu tipo e dimensão, seu público alvo, os recursos humanos e físicos disponíveis e o tipo de material didático que disponibilizam.

A seguir são descritos alguns critérios usados para caracterizar instituições e cursos a distância. Ademais veremos como a instituição que oferece cursos a distância é administrada, a qual geração de educação ela pertence, qual regime de aprendizado é oferecido e quais são as tecnologias utilizadas.

\section{Organização Administrativa}

As instituições que oferecem educação a distância, podem ser classificadas em 5 níveis, segundo Moore e Kearley (2008):

- Instituição com finalidade única - quando a instituição tem como única finalidade a educação a distância. Tendo todo o seu corpo docente e administrativo totalmente para esse modelo de educação.

- Instituição com finalidade dupla - é aquela que tem o ensino tradicional, presencial e também oferece cursos a distância. A instituição com finalidade dupla estabelece uma unidade especial para cuidar dos assuntos referentes à educação a distância e também tem o apoio da estrutura tradicional de professores e administradores.

- Professores individuais - é disponibilizado por professores em particular, sem estar vinculado a um modelo de educação a distância como um todo. Podem ser oferecidos cursos de áreas específicas, porém, não terá uma unidade especializada capaz de fornecer maiores condições de infraestrutura para o aluno como: biblioteca virtual e editora para a impressão dos livros didáticos. Esse modelo é normalmente adotado em cursos de curta duração. Esse tipo de ensino raramente resulta em obter uma educação a distância de alta qualidade e dificilmente consegue mantê-la durante muito tempo. 
- Universidade e consórcios virtuais - o termo virtual consiste em descrever o consórcio - um arranjo organizacional de duas ou mais instituições que operam juntas na criação e transmissão de cursos ou em ambas.

- Cursos e Programas - O que faz um curso ser considerado como sendo a distância não é a tecnologia empregada ou a sua duração. Essa modalidade ocorre quando o curso não é simplesmente uma adaptação do programa presencial para o modelo a distância por meio da disponibilização de conteúdo on line. Na verdade, em curso a distância deve ser desenvolvido considerando essa modalidade e sendo administrado levando em conta as particularidades inerentes à educação a distância.

\section{Gerações de Educação a distância}

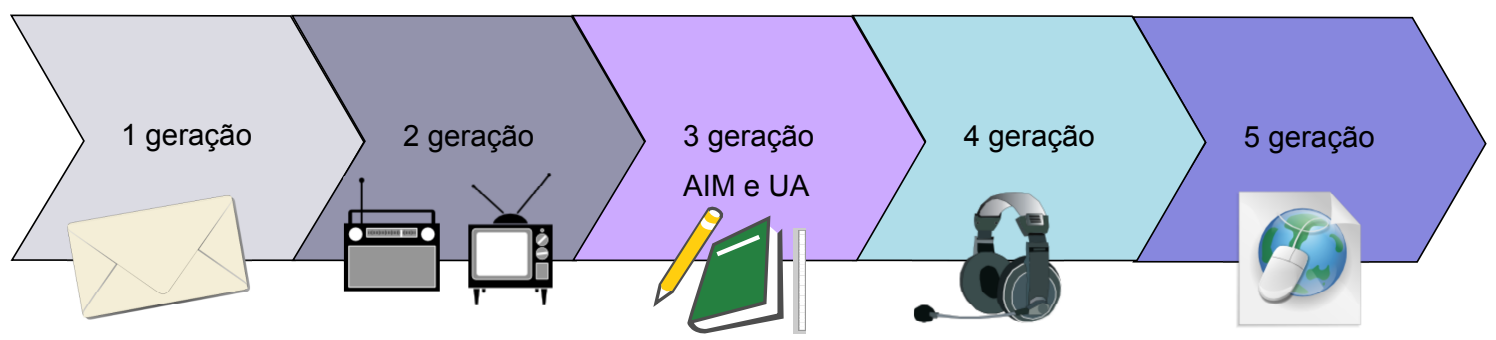

Figura 2.1: As gerações da EaD, desde a sua criação até os dias de hoje, baseado em Moore e Kearley (2008)

A educação a distância teve inicio muito antes da Internet, em 1880, por meio de correspondências. Então, de acordo com as tecnologias empregadas, pode-se classificar as iniciativas por gerações, conforme ilustra a Figura 2.1 elas são:

- Primeira Geração: caracterizou-se pelo uso de cartas. Também conhecido como estudo em casa, foi criado pelas primeiras escolas sem fins lucrativos, e estudo independente pelas universidades. O intuito dos primeiros educadores por correspondência era usar a tecnologia, da época, para chegar até aqueles que de outro modo não poderiam se beneficiar dela. Um fator que possibilitou o desenvolvimento desse modelo foi o estabelecimento de serviços postais baratos e confiáveis.

- Segunda Geração: transmissão por rádio e televisão. Com o surgimento do rádio no início do século $\mathrm{XX}$, esta tecnologia foi vista como grande possibilidade de difusão de conhecimento. Os primeiros cursos não obtiveram muito sucesso devido aos diferentes interesses entre a emissora de rádio e as instituições que estavam preparando os cursos, conforme constata Moore e Kearley (2008). A TV educativa obteve mais sucesso que o rádio e também maiores incentivos por meio de leis que fomentam 
a criação de estações de televisão educativa. Esse modelo foi utilizado tanto para cursos de curta duração como cursos completos de nível superior e para qualificação dos funcionários de empresas privadas. Foi nessa geração que surgiu a transmissão de cursos pela tv a cabo e também os cursos conhecidos como telecursos. Além da transmissão, eram oferecidos materiais impressos de apoio como guias de estudo, materiais didáticos e guias para o corpo docente e para a administração. No Brasil, esse modelo ainda é muito utilizado para o ensino de matérias de nível técnico e profissionalizante como o Telecurso $200{ }^{1}$

- Terceira Geração: Projeto de Mídia de Instrução Articulada (AIM - Articulated Instructional Media Project) e as Universidades Abertas (UA). O objetivo principal do primeiro era agrupar várias tecnologias de comunicação, a fim de proporcionar um ensino de alta qualidade e com custo reduzido para alunos não-universitários. As tecnologias incluíam guias impressos e orientações por correspondência, transmissão por rádio e televisão, conferências por telefone, kits para experiência em casa e recursos de bibliotecas locais.

Já a Universidade Aberta, que teve início em 1967, usava recursos tecnológicos como o rádio e a televisão. A grande diferença em relação às AIMs foi a não vinculação a outra instituição de ensino presencial já estabelecida, uma vez que a UA é uma instituição totalmente dedicada à finalidade de educação a distância a qualquer adulto que esteja interessado na educação fazendo uso dessa modalidade. Sua qualidade é equivalente à do modelo presencial no Reino Unido, como relata Moore e Kearley (2008).

No Brasil, o termo Universidade Aberta se enquadra mais na descrição de AIM, pois não se trata de uma instituição completamente desvinculada das tradicionais instituições de ensino superior ou de ensino técnico e profissionalizante e sim um departamento dedicado a essa modalidade que aproveita também o conhecimento e o corpo docente dos cursos presenciais.

- Quarta Geração: A Teleconferência. Surgiu nos Estados Unidos em 1980. Era um modo mais próximo ao ensino tradicional pois os alunos poderiam se reunir em uma sala de aula convencional ou mesmo em suas residências. Todavia, era exigido o uso de equipamento específico para a transmissão e o recebimento de áudio e imagem. A comunicação podia ser estabelecida por satélite e possibilitar uma videoconferência interativa, aproximando os alunos e professores e, inclusive, uns dos outros.

${ }^{1}$ Site oficial: http://www.telecurso2000.org.br 
O uso dessa tecnologia foi explorado muito além do ensino superior. Foi utilizado com fins comerciais no caso de empresas que as usavam para treinar seus funcionários, e alugavam links da transmissão por satélite para tornar isso possivel. Inicialmente, a teleconferência poderia ser realizada em vídeo somente em um sentido, ou por áudio nos dois sentidos. Na década de 90, a videoconferência se tornou amplamente disponível.

- Quinta Geração: Aulas Virtuais pelo computador e Web. O computador e, principalmente, a Internet, possibilitaram uma nova fase da educação a distância. Os cursos agora eram disponibilizados na Web e poderiam ser acessados em qualquer horário por um computador pessoal e os alunos poderiam acessar diversos conteúdos, sejam textos, vídeos, áudio e diversas ferramentas de comunicação como chat, conversa com vídeo etc. Com isso também surgiram novas ideias a respeito de como organizar a educação a distância.

Regime de aprendizado

As instituições de ensino se organizam de acordo com o público alvo e suas características de infra estrutura. Segundo Coelho (2007) existem três tipos de regime de aprendizado a distância:

1. EaD "puro": é caracterizado pelo aluno autodidata que pode escolher qual é o melhor horário e melhor local para o seu estudo. Não sendo necessária nenhuma atividade presencial, exceto os exames finais que são obrigatórios para os níveis de ensino continuado aprovados pelo MEC.

2. EaD: é caracterizado por ter alguns elementos do ensino presencial como sala de aula, frequência e participação dos alunos em atividades como seminários, oficinas, etc.

3. Mistos de EaD e educação convencional: este regime pode ser aplicado, por exemplo, em situações nas quais a instituição de ensino presencial ofereça programas complementares na modalidade EaD como reforço, para atender outros alunos da comunidade. O MEC autoriza por meio da Portaria 4.059, de 10-12-04 que até 20\% da carga total do curso siga o modelo semipresencial e seja ministrada via Web.

\section{Tecnologias Utilizadas}

Segundo Moore e Kearley (2008) tecnologia é o veículo para comunicar mensagens, e essas estão representadas por meio do uso de uma mídia. $\mathrm{O}$ autor comenta a respeito do uso excessivo da tecnologia e a falta de preocupação com a qualidade das mídias utilizadas, pois nem sempre o aluno terá 
acesso a mais nova tecnologia disponível. Talvez seja mais proveitoso usar uma tecnologia intermediária que tenha qualidade e facilite o aprendizado do aluno, ao invés de uma tecnologia recente que dificulte ou não acrescente muito ao aluno.

As seções seguintes descrevem algumas tecnologias utilizadas em EaD. Essas tecnologias podem ser caracterizadas de acordo com a interatividade que elas proporcionam, como:

- Sem interatividade - quando o usuário é somente um receptor das informações disponibilizadas;

- Interativo - quando o usuário interage, retornando informações. Essa interação pode ser classificada em duas categorias quando levamos em consideração o tempo de resposta dessa interação:

- Síncrono - quando a resposta é fornecida "ao mesmo tempo"em que é enviada uma pergunta. Por exemplo, um aluno tem uma dúvida e pergunta ao professor. O professor responde logo em seguida.

- Assíncrono - quando a resposta é fornecida em tempo diferente da pergunta. Por exemplo, usando um fórum de discussão um aluno deixa postada uma dúvida e, quando o professor entrar no ambiente e visualizar a dúvida, ele a responde.

Tabela 2.1: Tecnologias utilizadas em EaD

\begin{tabular}{|c|c|c|c|c|}
\hline Tecnologia & Mídias Utilizadas & Interatividade & Retorno das Inf. & Uso \\
\hline Livro didático & $\begin{array}{c}\text { imagem } \\
\text { texto }\end{array}$ & sem interatividade & sem retorno & individual \\
\hline Material on line & $\begin{array}{c}\text { imagem } \\
\text { texto } \\
\text { áudio }\end{array}$ & assíncrono & sem retorno & individual \\
\hline CD ou DVD & $\begin{array}{c}\text { imagem } \\
\text { texto } \\
\text { áudio }\end{array}$ & sem interatividade & sem retorno & individual \\
\hline Radio & áudio & sem interatividade & sem retorno & coletivo \\
\hline Televisão & $\begin{array}{c}\text { áudio } \\
\text { imagem }\end{array}$ & sem interatividade & sem retorno & coletivo \\
\hline Televisão Interativa & $\begin{array}{c}\text { áudio } \\
\text { imagem } \\
\text { texto }\end{array}$ & síncrono e assíncrono & com retorno & coletivo \\
\hline Vídeoconferência & $\begin{array}{l}\text { áudio } \\
\text { imagem }\end{array}$ & síncrono & com retorno & individual \\
\hline $\begin{array}{c}\text { Ambiente Virtual } \\
\text { de Aprendizagem (AVA) }\end{array}$ & $\begin{array}{c}\text { áudio } \\
\text { texto } \\
\text { imagem }\end{array}$ & $\begin{array}{l}\text { síncrono } \\
\text { assíncrono }\end{array}$ & com retorno & coletivo \\
\hline
\end{tabular}




\subsection{Learning Management System (LMS)}

A educação a distância pode ser oferecida utilizando de diversas tecnologias. Esta seção caracteriza plataformas Web que oferecem suporte a essa modalidade de ensino, conhecidas como LMS (Learning Management System Sistema de Gestão da Aprendizagem).

A partir do aprimoramento da Web, os ambientes criados pelas Tecnologias de Informação e Comunicação (TIC) digital têm chamado a atenção dos pesquisadores quanto à sua utilização na área de educação. Os Ambientes Virtuais (AV) destinados a essa área recebem denominações diferentes. O termo atualmente mais usado é "ambiente virtual de aprendizagem"(AVA). O conceito de ambiente é definido nos limites da área de educação como um espaço propício para criar novas oportunidades de aprendizagem - ou seja, o ambiente informatizado é uma nova condição de produção de conhecimento, baseada na ideia de colaboração entre os indivíduos e da formação de uma consistente comunidade de aprendizagem. Os LMSs são softwares desenvolvidos com base em uma metodologia pedagógica para auxiliar a promoção de ensino e de aprendizagem virtual ou semipresencial. Segundo Moore e Kearley (2008) todos esses sistemas têm capacidade de estabelecer comunicações síncronas e assíncronas em uma plataforma, bem como o acesso a outros tipos variados de conteúdos. Neste Capítulo serão apresentados três LMSs e suas principais funcionalidades.

\subsubsection{TelEduc}

O ambiente virtual de aprendizagem TelEduc, ${ }^{2}$ concebido para apoiar o processo de formação de professores em informática educativa, tem por objetivo o apoio a criação, a participação e a administração de cursos via Web. Foi desenvolvido por pesquisadores do Nied (Núcleo de Informática Aplicada à Educação) ${ }^{3}$ da Unicamp, considerando as necessidades dos usuários o que o torna de fácil uso para pessoas que não são da área de computação e possuem menor habilidade em lidar com ferramentas computacionais.

Segundo Lachi (2003) o TelEduc foi criado em 1997 e a partir de 2002 passou a ter licensa GPL(General Public Licence) e é disponibilizado para download no site oficial para qualquer pessoa interessada em fazer uso desse ambiente, sendo recomendado o uso de um servidor com uma distribuição Linux instalado. Foi desenvolvido utilizando as linguagens: PHP, JavaScript e MySQL.

Segundo seus criadores o TelEduc as ferramentas disponibilizadas podem se agrupar em 3 grupos de ferramentas: de cordenação, de comunicação e de

\footnotetext{
${ }^{2}$ Disponível em: http://www.teleduc.org.br/

${ }^{3}$ http://www.nied.unicamp.br/
} 
administração.

Algumas das ferramentas assíncronas disponíveis são: o correio eletrônico e o fórum de discussão. Já em relação às ferramentas síncronas disponíveis temos, por exmplo, o chat e a videoconferência. Possui também ferramentas colaborativas como, por exemplo, editor de texto colaborativo, (Simões e Lindemann, 2007).

\subsubsection{Moodle}

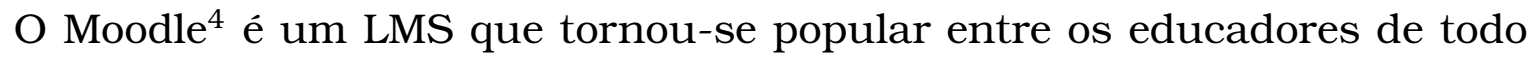
o mundo. A plataforma, que oferece suporte para a criação de conteúdo e o acompanhamento de alunos, é multiplataforma, tem licença GNU-GPL e foi desenvolvido em PHP. Foi desenvolvido por Dougiamas e Taylor (2002) com o intuito de servir de ambiente para a aprendizagem colaborativa. Assim, o Moodle foi desenhado para apoiar e promover a integração entre as pessoas interessadas em desenvolver ambientes de aprendizagem construtivista (Dougiamas e Taylor, 2002).

Um dos principais recursos síncronos disponíveis para o desenvolvimento das atividades é a ferramenta chat. Já os assíncronos são: materiais, avaliação do curso, diário, fórum, glossário, lição, pesquisa de opinião, questionário, SCORM, tarefa, trabalho com revisão e wiki. Suas funcionalidades são extensíveis e contém outros inúmeros recursos oficiais além daqueles desenvolvidos pela comunidade.

O Moodle foi homologado pelo MEC como plataforma oficial para Educação a Distância, e deverá ser adotado por quaisquer instituições que queiram aplicar esta modalidade de ensino. Devido a essa homologação, os cursos a distância da UAB (Universidade Aberta do Brasil) e também de outras IFES (Instituições Federais de Ensino) são mediados por essa plataforma.

\subsubsection{Tidia-Ae (Tecnologia da Informação no Desenvolvimento da Internet Avançada - Aprendizado eletrônico)}

O intuito dos pesquisadores responsáveis pelo projeto Tidia-Ae ${ }^{5}$ é desenvolver um ambiente de colaboração de suporte e apoio ao ensino e aprendizagem com interações presenciais e à distância, síncronas e assíncronas. O sistema de aprendizado visa apoiar instituições de ensino, empresas e fundações em suas atividades educacionais.

Os objetivos do projeto Tidia-Ae são: a pesquisa e o desenvolvimento de software na área de tecnologia da informação voltados para a especificação,

\footnotetext{
${ }^{4}$ Disponível em http://moodle.org/ e http://www.moodlebrasil.net

${ }^{5}$ Disponivel em: http://tidia-ae.incubadora.fapesp.br/
} 
o planejamento e a implementação de ferramentas no contexto educacional. De acordo com Motti (2009) o projeto Tidia-Ae visa propor soluções flexíveis de grande impacto social a um baixo custo, disponibilizando seus resultados como software de código aberto e gratuito, (Lince-DC, 2010).

O Projeto Tidia-Ae estabeleceu uma parceria com o Projeto Sakai ${ }^{6}$, o que acarretou benefícios para ambos projetos. O Sakai não contempla a utilização de redes de alta velocidade, o que limita o uso de conteúdo multimídia, como áudio e vídeo em suas ferramentas síncronas. Esse é um dos aspectos dentre os quais o Tidia-Ae mais tem contribuído com o Sakai.

A parceria Tidia-Sakai pode se beneficiar da experiência adquirida com o desenvolvimento de ferramentas síncronas do Tidia-Ae e da robustez e da estabilidade oferecidos pelo framework Sakai para o desenvolvimento de ferramentas para educação a distância. O Tidia-Ae possui ferramentas síncronas como: o comunicador instantâneo (Lobato e Baldochi Jr, 2005), o chat (Moraes e Santos, 2008), a whiteboard (Jardim e Martelini Jr, 2005) e a vídeoconferência (Lince-DC, 2010). Além de ferramentas assíncronas como o fórum e colaborativas como a wiki e a whiteboard.

\subsection{Ferramentas de software disponibilizadas em LMS}

Esta seção lista algumas ferramentas que têm por objetivo apoiar cursos oferecidos na modalidade a distância. Elas foram escolhidas por fazer parte do ambiente Tidia-Ae.

\subsubsection{Chat}

A ferramenta chat (Moraes e Santos, 2008) é uma ferramenta de comunicação textual entre participantes de uma sessão síncrona. Tem por objetivo promover discussões interativas por meio de texto entre duas ou mais pessoas simultaneamente, e permitem o envio de mensagens para todos os usuários conectados ou para um usuário específico. As discussões podem ser gravadas para acesso e análise posterior. Para usar-la deve-se planejar o que é definido como uma sessão, na qual todos os participantes selecionados podem trocar mensagens de texto de modo distribuído.

\subsubsection{Whiteboard}

A whiteboard (Jardim e Martelini Jr, 2005) é uma ferramenta colaborativa para desenho feito com caneta eletrônica. A whiteboard vai além ao permitir o desenho colaborativo. Para usar-la deve-se planejar o que é definido como

\footnotetext{
${ }^{6}$ Disponível em: http://sakaiproject.org/
} 
uma sessão, na qual todos os participantes selecionados podem se conectar de modo distribuído, trocar anotações e até mesmo intervir no trabalho anotado (por exemplo, por meio de um professor remoto). Existe uma sessão padrão que pode ser utilizada a qualquer momento, sem a necessidade de configuração inicial. A ferramenta fornece um conjunto de operações cujas funções permitem: uso de diferentes espessuras de caneta e cores, uso de figuras geométricas pré-definidas, uso de recursos para copiar/recortar/colar/mover objetos, desfazer e refazer ações, apagar objetos, duplicar ou criar novos slides, linhas de grade (útil para gráficos). Para acesso aos slides, pode-se navegar utilizando os ícones de "próximo", "anterior"ou por intermédio de miniaturas. A ferramenta permite a identificação dos participantes conectados ou não na sessão, e registra o autor de cada ação durante a captura. Após a finalização de uma sessão (de ensino-aprendizagem), pode-se disponibilizar os slides com as anotações na Web, por meio de imagens com o conteúdo capturado.

No caso do Tidia-Ae (Motti, 2009), a whiteboard pode ser utilizada para apresentações que fazem uso de um conjunto de slides preparados com antecedência, pois, além de exibir os slides, permite ao usuário anotar sobre eles usando uma caneta eletrônica (ou teclado e mouse convencional). A ferramenta da whiteboard possui função de acessibilidade, considerando deficientes visuais ou usuários com leitor de tela. Essa funcionalidade é disponibilizada para o perfil de instrutor, uma opçao de inclusão de uma descrição sobre os traços desenhados. O participante seleciona um conteúdo na tela, clica sobre o botão com o ícone de acessibilidade, digita uma descrição para o conteúdo e especifica a posição do conteúdo na tela. As descrições são disponibilizadas para acesso durante ou depois de uma sessão.

\subsubsection{Fórum}

Permite o envio de mensagens, mas essas não são enviadas para as caixas postais. Elas são armazenadas hierarquicamente, agrupadas pelos temas em aberto, de forma a facilitar o registro e o acompanhamento das discussões sobre vários assuntos.

Segundo Moore e Kearley (2008), muitos instrutores tem considerado esta ferramenta como valiosa por permitir que alunos e instrutores interajam enviando e lendo mensagens, ao passo que cada um possui flexibilidade em relação a quando fazê-lo.

\subsubsection{Vídeoconferência}

Esta ferramenta permite que os usuários se comuniquem sincronamente por meio de áudio e vídeo. Essa ferramenta requer a utilização de dispositivos 
como câmera de vídeo, microfone, equipamentos especiais para digitalização e compressão de som e imagem e conexão de rede de velocidade, típica de redes cabeadas. Geralmente a videoconferência é externa aos ambientes virtuais de aprendizagem dada a sua complexidade de implementação. É uma ferramenta síncrona que exige que os alunos estejam conectados em um horário prédefinido para participarem da sessão.

\subsubsection{Wiki}

Wiki é uma ferramenta que possibilita a autoria assíncrona de páginas Web de modo colaborativo, possibilitando que pessoas que não tenham experiência em programação criem suas próprias páginas. Seu uso pode ser o mais variado possível, além de apoio ao ensino presencial e a distância.

Segundo Klobas (2006) o termo wiki é usado tanto para wiki sites quanto para o software usado para mantê-los. Wiki sites são coleções de documentos interligados e editáveis via browser. Eles são Websites que podem ser desenvolvidos, modificados e estendidos pelos leitores.

A wiki tem como princípio tornar transparente para o usuário as complexidades de um documento HTML de modo a tornar seu uso intuitivo para os usuários. Sendo assim, trata-se de uma ferramenta muito interessante para pessoas que não são da área de computação disseminarem o conhecimento aprendido e entre um grupo de pessoas, (Klobas, 2006).

De acordo com Klobas (2006) as wikis são importantes vários em casos. Na educação, é uma ferramenta útil na gestão de pessoas e de fontes de informação. Essa ferramenta possibilita aos educadores oportunidades de aprendizado com interatividade, autenticidade e ainda tem finalidade social. Na sala de aula colaborativa, a wiki tem se mostrado uma ferramenta bem sucedida, possibilitando o acesso, a motivação e a socialização on-line. Devido à facilidade de edição de conteúdo, ela motiva o estudante a compartilhar suas experiências.

\subsection{TV Digital}

O Sistema Brasileiro de TV Digital (SBTVD) foi instituído pelo Decreto presidencial 4.901, de 26 de novembro de 2003, que elencou os objetivos a serem atingidos com o Sistema Brasileiro de TV Digital. Hoje é conhecido como ISDTV (International System for Digital Television).

No âmbito do ISDTV, as aplicações interativas operam sobre o middleware brasileiro conhecido como Ginga. Esse middleware é subdividido em dois subsistemas interligados que permitem o desenvolvimento de aplicações seguindo 


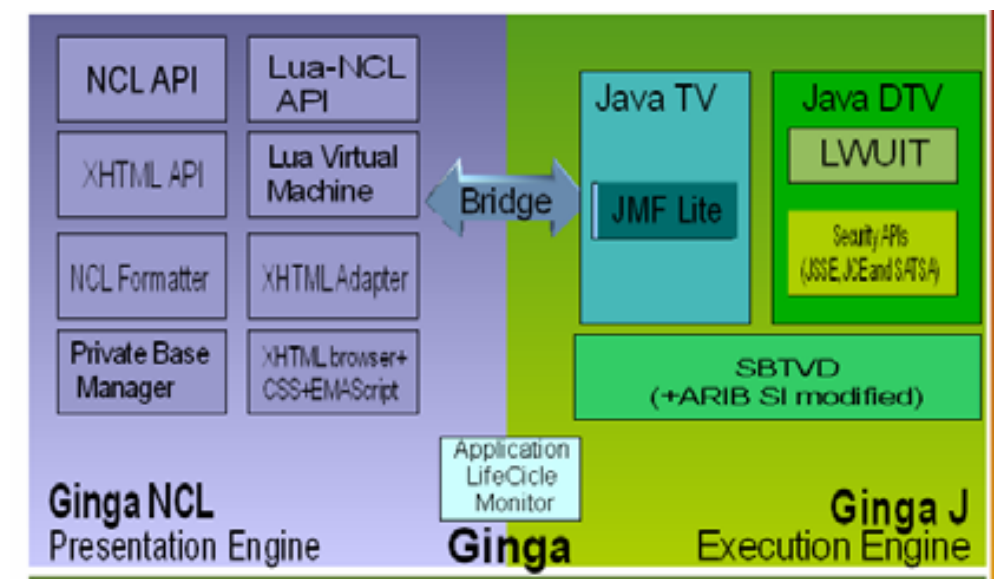

Figura 2.2: A parte da máquina de execução e da máquina de apresentação do Ginga, baseado em GINGA (2009)

dois paradigmas distintos de desenvolvimento, (GINGA, 2009): Ginga-J (Soares et al., 2007a), para aplicações procedurais em Java; e Ginga-NCL (Soares et al., 2007b), para aplicações declarativas em NCL (Nested Context Language).

Segundo a ABNT 15606 a arquitetura do middleware para a televisão interativa do ISDTV pode ser representada basicamente por dois importantes componentes: a máquina de execução (execution engine) e a máquina de apresentação (presentation engine), conforme mostra a Figura 2.2. Esses componentes não podem ser independentes, por isso foram definidas pontes que interligam essas máquinas. Adicionalmente a esses componentes básicos, podem existir aplicações nativas ou outros softwares específicos e de conteúdo.

A Figura 2.3 ilustra a de protocolos e as camadas existentes na TVD, especificamente no middleware Ginga. Uma aplicação para esse sistema poderá usufruir de quaisquer APIs especificadas nesse cenário.

\subsection{Considerações Finais}

Sistemas do tipo LMS são plataformas que auxiliam usuários de cursos oferecidos a distância. Eles podem ser configurados da maneira que for conveniente para o curso em questão. O ambiente Tidia-Ae possui avanços em relação às demais plataformas apresentadas no desenvolvimento de ferramentas colaborativas como a whiteboard.

Esse projeto estudou o uso LMS Tidia-Ae em ambientes web e também em TV Digital, para isso foi estudado quais ferramentas do LSM se adequam melhor para cada situação. 


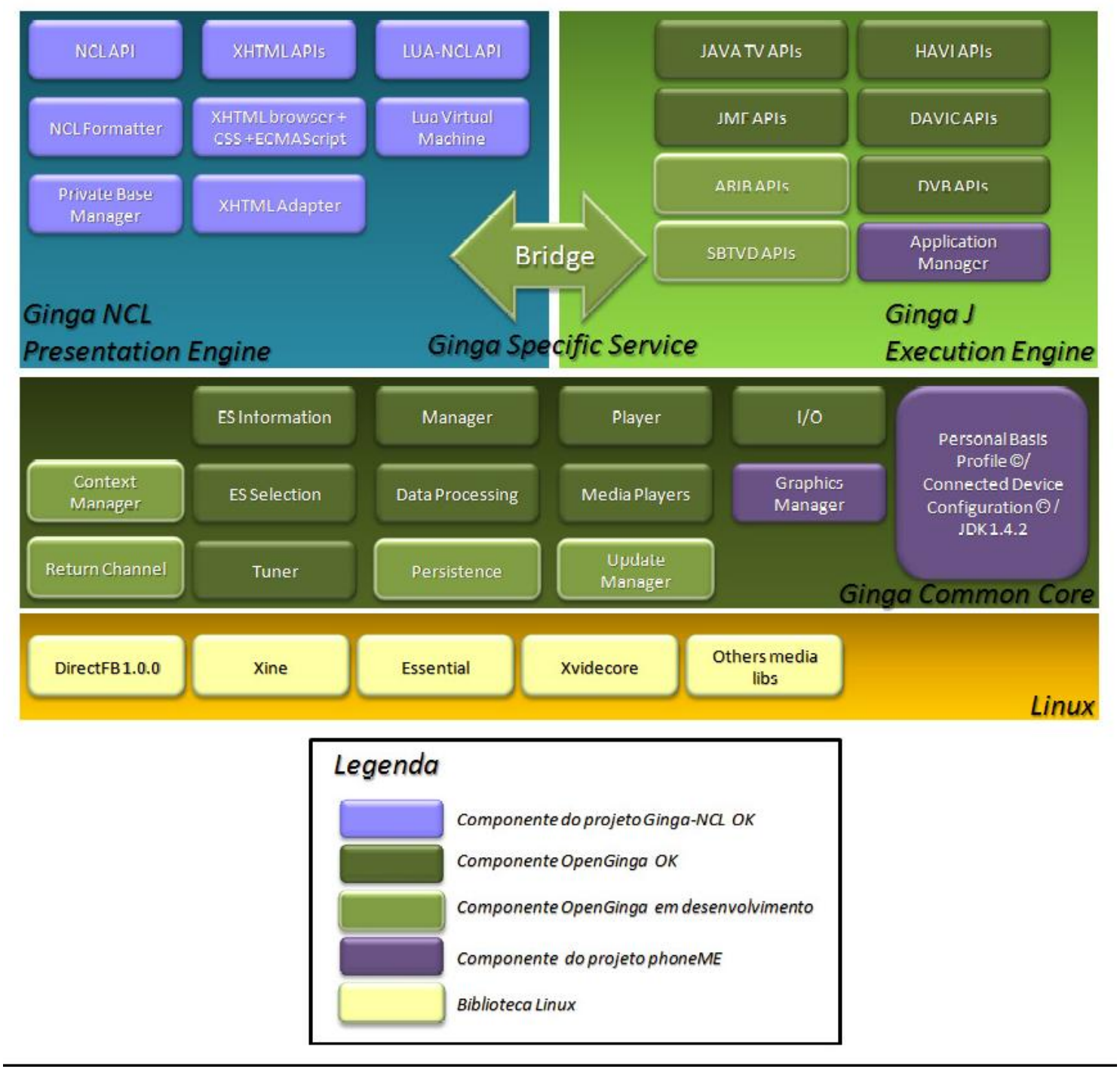

Figura 2.3: Visão Geral da pilha de protocolos utilizado no middleware GINGA, baseado em GINGA (2009) 


\section{CAPÍTULO 3 \\ Projetos desenvolvidos no estado do Amazonas}

\subsection{Considerações sobre o estado do Amazonas}

O estado do Amazonas possui uma área de $1.570 .947 \mathrm{~km}^{2}$, representando 40,77 \% da Região Norte e 18,45 \% de todo o território nacional, sendo então o maior estado brasileiro em valores territoriais. Sua área comparada com os demais estados brasileiros é pouco menor que a área da Região Nordeste, com seus nove estados, e seis vezes maior que o estado de São Paulo. Aliados a esse universo verde estão os rios, lagos e igarapés, elementos marcantes característicos dessa área.

O Amazonas é banhado pela bacia hidrográfica amazônica, que corresponde a aproximadamente $20 \%$ da água doce do planeta. Os principais rios amazonenses são navegáveis durante todo o ano, conforme Figura 3.1. No Amazonas, os rios servem como estradas e as enormes distâncias são medidas em horas ou em dias de viagem de barco.

O estado é dividido em 62 municípios, e tem como capital a cidade de Manaus. Sua população é de 3.323.330, sendo que 1.709.010 habitantes estão localizados na capital. O estado de São Paulo é 13 vezes mais populoso que o Amazonas. De acordo com as estimativas do IBGE, a densidade demográfica do estado é de 2,05 hab $/ \mathrm{km}^{2}$ enquanto a de São Paulo é de 160,4 hab. $/ \mathrm{km}^{2}$.

Com relação à produção de riquezas e às economias dos municípios do estado, a Tabela 3.1 apresenta dados dos 6 municípios do estado do Amazonas com PIB (Produto Interno Bruto) superior a R\$ 250 milhões de reais. Os 


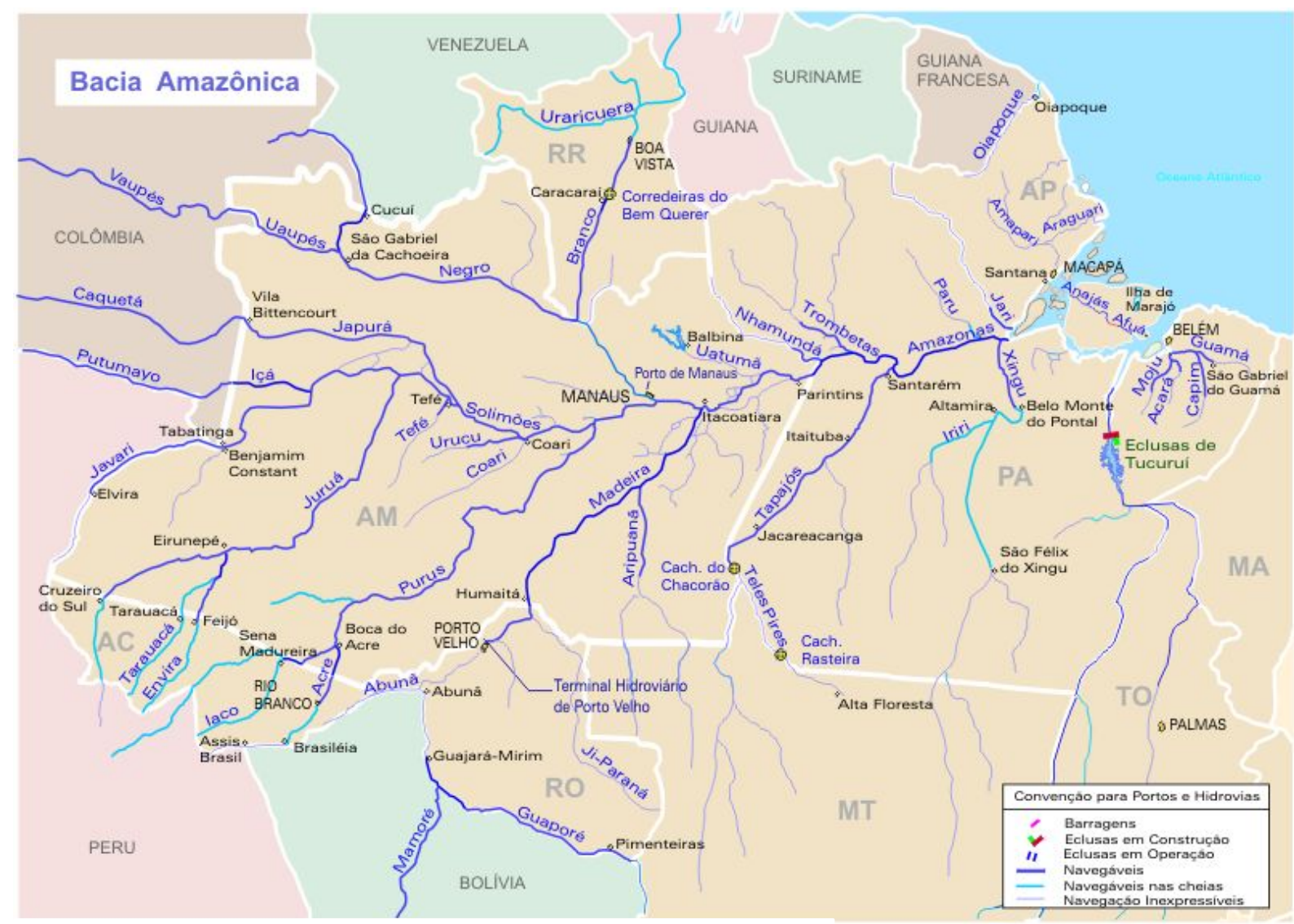

Figura 3.1: A bacia hidrográfica do estado do Amazonas mostrando a imensa quantidade de rios navegáveis que cortam todo o estado.

Fonte: Ministério dos Transportes

valores referem-se ao ano de 2005, segundo o IBGE, e os dados demográficos são relativos a 2007. Como pode ser percebido, existe uma grande diferença populacional entre a capital e as demais cidades do estado.

As estradas do estado são, de fato, as rodovias. Como observado na Figura 3.2, existe somente uma estrada que liga o Amazonas a outro estado do país e mesmo assim o liga unicamente a esse estado e possui trechos que só podem serem transitados durante o dia. O Amazonas possui também somente três estradas que ligam a capital a poucos municípios próximos. Esses dados ressaltam o quanto que os municípios amazonenses são isolados geograficamente e o fato de que os acessos só são possíveis se envolvem dias de percurso a barco ou de avião.

\subsubsection{Educação no Amazonas}

O Amazonas possui várias instituições educacionais, sendo que as mais renomadas delas estão localizadas principalmente na Região Metropolitana de Manaus e em outras cidades de médio porte. Sua taxa de analfabetismo corresponde a $7,8 \%$ de sua população analfabeta(oitavo lugar no ranking na- 
Tabela 3.1: PIB e população das principais cidades do estado do Amazonas. Fonte: IBGE

\begin{tabular}{|c|c|c|c|c|}
\hline Posição & Cidade & PIB (R\$) & População & Base da economia \\
\hline 1 & Manaus & 27.214 .213 & 1.646 .602 & $\begin{array}{c}\text { Indústria, } \\
\text { comércio e turismo }\end{array}$ \\
\hline 2 & Coari & 980.166 & 67.055 & $\begin{array}{c}\text { Indústria farmoquímica, } \\
\text { petróleo e gás natural }\end{array}$ \\
\hline 3 & Itacoatiara & 455.619 & 87.896 & $\begin{array}{c}\text { Indústria, comércio, } \\
\text { prestação de serviços, } \\
\text { turismo e agropecuária }\end{array}$ \\
\hline 4 & Parintins & 312.226 & 105.742 & $\begin{array}{c}\text { Agropecuária, } \\
\text { turismo e indústria }\end{array}$ \\
\hline 5 & $\begin{array}{c}\text { Presidente } \\
\text { Figueiredo }\end{array}$ & 303.882 & 25.474 & $\begin{array}{c}\text { Prestação de serviços } \\
\text { e turismo. }\end{array}$ \\
\hline 6 & Manacapuru & 282.213 & 85.279 & $\begin{array}{c}\text { Agropecuária, comércio } \\
\text { e prestação de serviços }\end{array}$ \\
\hline
\end{tabular}

cional).Em 2001 o estado aparecia em décimo quinto lugar, com 15,5\% de sua população analfabeta, IBGE.

As dificuldades para superação do analfabetismo em todo país são causadas por diversos motivos. No Amazonas, por exemplo, onde a taxa de 7,8\% de analfabetismo é a segunda menor da Região Norte (perdendo apenas para o Amapá), as principais reclamações da população se referem à insuficiência do número de escolas para suprir a demanda de alunos, tanto no nível fundamental quanto no nível médio, (Coelho, 2007). A esse problema se soma a dificuldade de reunir alunos em áreas centrais de estudo devido à distância entre as inúmeras comunidades ribeirinhas e indígenas, à falta de estrutura educacional nessas áreas, e à pouca disponibilidade de professores qualificados.

A Tabela 3.2 apresenta o resultado do ENEM (Exame Nacional do Ensino Médio) para as instituições de ensino do estado nos anos de 2006 a 2008, levando em consideração as médias nacionais e a posição do estado em relação a outros estados brasileiros.

Tabela 3.2: Resultado do ENEM em três anos no estado do Amazonas com a sua colocação em relação as pontuações nacionais. Fonte: ENEM

\begin{tabular}{|r|r|r|r|r|r|r|}
\hline & \multicolumn{3}{|c|}{ Português } & \multicolumn{3}{c|}{ Redação } \\
\hline & AM & Nac. & Colocação & AM & Nac. & Colocação \\
\hline $\mathbf{2 0 0 6}$ & 30,85 & 36,9 & 26 & 49,73 & 52,08 & 18 \\
\hline $\mathbf{2 0 0 7}$ & 42,87 & 51,52 & 26 & 54,09 & 55,99 & 20 \\
\hline $\mathbf{2 0 0 8}$ & 34,56 & 41,69 & 27 & 58,5 & 59,35 & 14 \\
\hline
\end{tabular}

O conceito do ENADE é calculado pela média ponderada da nota padronizada dos concluintes de cada curso, nas áreas específicas, da nota padro- 


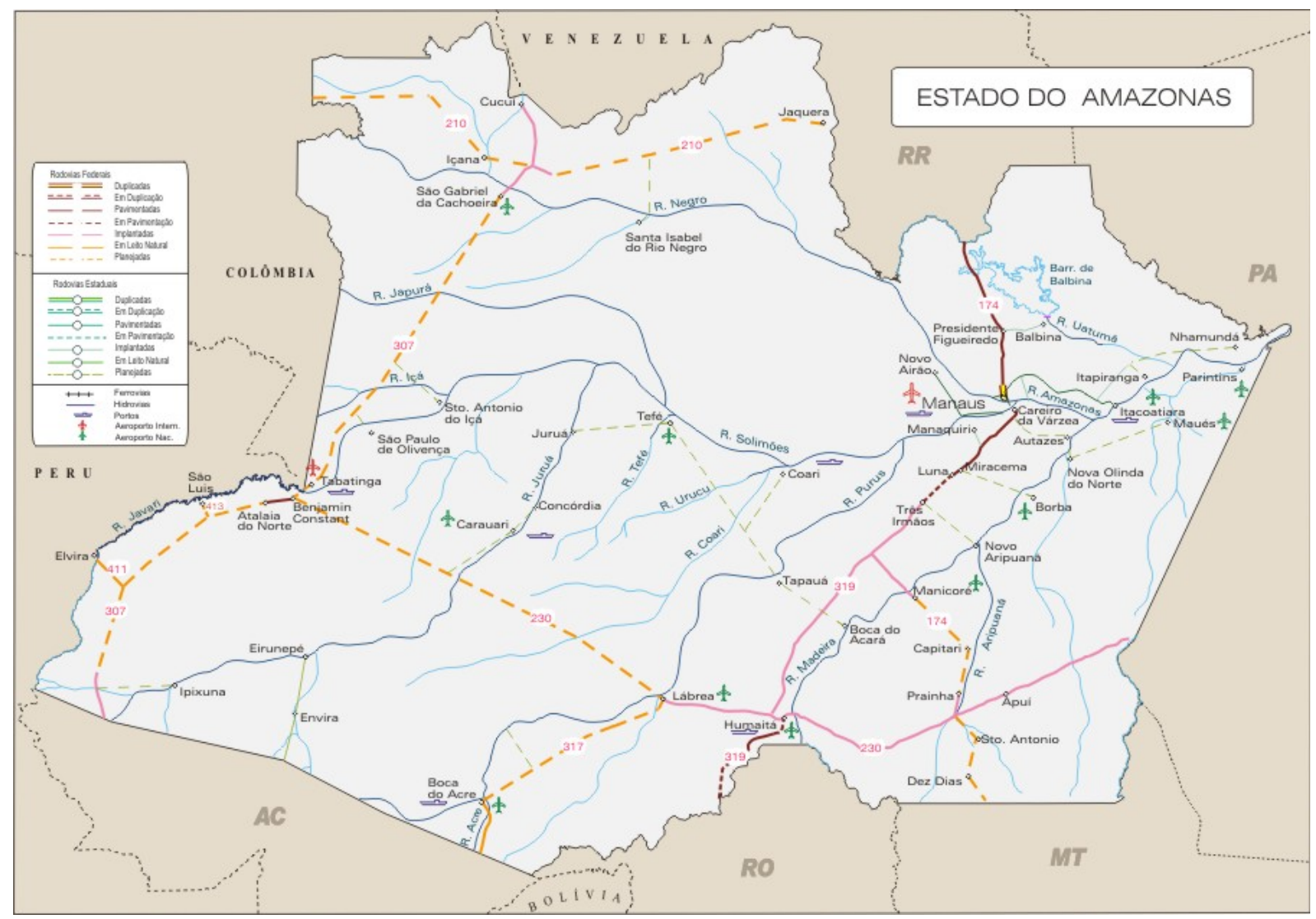

Figura 3.2: As estradas existentes no estado do Amazonas Fonte: Ministério dos Transportes

nizada dos ingressantes no componente específico e da nota padronizada em formação geral (concluintes e ingressantes). Essas notas possuem, respectivamente, os seguintes pesos: $60 \%, 15 \%$ e $25 \%$.

Assim, a parte referente ao componente específico contribui com $75 \%$ da nota final do curso, enquanto que a parte de formação geral contribui com 25\%. O conceito é apresentado em cinco categorias ( 1 a 5), sendo que 1 é o resultado mais baixo e 5 é o melhor resultado possível, na área. O Curso poderá estar sem Conceito (SC) quando não tem estudante (ingressante ou concluinte) selecionado na amostra que participou do exame. Podem existir três motivos: (1) menos de 11 ingressantes participantes; (2) menos de 11 concluintes participantes; e (3) nota zero.

A Tabela 3.3 apresenta o resultado do ENADE (Exame Nacional de Desempenho de Estudantes) 2008, das instituições de ensino Superior no estado do Amazonas com um comparativo com os principais estados brasileiros.

\section{Considerações Finais sobre o Amazonas}

Com base nos números do ENEM e ENADE, é possivel perceber a dificuldade de ensino de qualidade no estado. Se observarmos o interior do estado vemos uma situação ainda mais agravante devido à falta de professores qua- 
Tabela 3.3: ENADE 2008, uma comparação entre o ensino superior nos principais estados do Brasil. Fonte: ENADE

\begin{tabular}{|r|r|r|r|r|r|r|r|r|r|r|r|r|}
\hline UF & \multicolumn{2}{|c|}{$\mathbf{1}$} & \multicolumn{2}{|c|}{$\mathbf{2}$} & \multicolumn{2}{|c|}{$\mathbf{3}$} & \multicolumn{3}{|c|}{$\mathbf{4}$} & \multicolumn{2}{|c|}{5} & \multicolumn{2}{|c|}{ SC } \\
\hline & & $\mathbf{\%}$ & & $\mathbf{\%}$ & & $\mathbf{\%}$ & & $\mathbf{\%}$ & & $\mathbf{\%}$ & & $\mathbf{\%}$ \\
\hline AM & 9 & 8,6 & 30 & 28,6 & 16 & 15,2 & 10 & 9,5 & 2 & 1,9 & 38 & 36,2 \\
\hline MG & 24 & 2,8 & 133 & 15,3 & 169 & 19,4 & 106 & 12,2 & 60 & 6,9 & 377 & 43,4 \\
\hline RJ & 34 & 5,8 & 116 & 19,9 & 150 & 25,7 & 91 & 15,6 & 50 & 8,6 & 142 & 24,4 \\
\hline SP & 80 & 4,6 & 385 & 22,0 & 473 & 27,1 & 194 & 11,1 & 48 & 2,7 & 567 & 32,5 \\
\hline PR & 15 & 2,8 & 92 & 17,2 & 174 & 32,5 & 87 & 16,3 & 22 & 4,1 & 145 & 27,1 \\
\hline
\end{tabular}

lificados residindo nas cidades e ainda à grande dificuldade de acesso a elas. Essa situação impede a chegada de profissionais qualificados provenientes da capital e o acesso a infraestrutura como Internet com banda larga superior a $512 \mathrm{kbps}$, que possibilitaria a aproximação entre os estudantes do interior e os da capital do estado.

\subsection{Cursos de EaD no AM}

Foi realizado um levantamento de projetos de educação a distância atualmente em funcionamento no estado do Amazonas, que oferecem cursos no interior do estado, seja ele de nível básico, técnico ou superior.

\subsection{Universidade Federal do Amazonas (UFAM)}

A UFAM ${ }^{1}$ foi fundada em 1909 e hoje oferece, presencialmente, 51 cursos de graduação e 19 de pós-graduação em nível de mestrado, sendo 13 credenciados pela Capes, 1 em nível de doutorado e cerca de 30 na modalidade lato sensu. Atualmente oferece, na modalidade a distância, 6 cursos de graduação e 4 de pós-graduação lato sensu. Dos 766 professores que atuam nas 11 unidades acadêmicas, 218 são doutores, 344 são mestres, 119 especialistas, e 85 graduados.

Universidade Federal do Amazonas criou o Centro de Educação a Distância $(\mathrm{CED})^{2}$ que atua em 11 municípios: Manaus, Maués, Coari, Itacoatiara, São Gabriel da Cachoeira, Parintins, Humaitá, Manacapuru, Lábrea, Eirunepé e Benjamin Constant. No processo de distribuição dos polos levou-se em conta: os municípios em que a UFAM tem campus instalado; o número de habitantes por município; o número de professores em exercício sem licenciatura e a estrutura de parcerias já existentes entre a Universidade Federal do Amazonas, Prefeituras Municipais e Governo do Estado. Os polos situam-se em locais

\footnotetext{
${ }^{1}$ http://portal.ufam.edu.br

${ }^{2}$ http://www.ced.ufam.edu.br/
} 
estratégicos com a finalidade de atender a maior parte da população. A população dos onze municípios representa aproximadamente $67 \%$ da população do Estado.

Cada polo é composto por municípios circunvizinhos agregados em torno de um município sede. A sede de cada polo é definida a partir dos campus já existentes na Universidade Federal do Amazonas. A organização das atividades de EaD em polos visa agregar os processos, os conteúdos e os sujeitos, assim como a logística administrativa, tecnológica e acadêmica dos municípios selecionados. Os cursos contam com o suporte de LMS para fazer a comunicação entre alunos e professores e, em alguns casos, contam com a parceria da TV UFAM ${ }^{3}$ para transmitir aulas e materiais complementares pela TV.

Em uma classificação dessa instituição segundo os conceitos expostos no Capítulo 4, a educação a distância promovida pela UFAM caracteriza-se da seguinte forma:

- Organização Administrativa: Finalidade Dupla;

- Geração de ensino: Quinta Geração;

- Regime de aprendizado: EaD;

- Tecnologias Utilizadas: AVA; CD-ROM; livros didáticos;

- Ferramentas e equipamentos utilizados: AVA; Internet;

- Profissionais envolvidos: tutor presencial; tutor a distância; professor;

- Nível dos cursos: nível superior;

- Cursos oferecidos: Curso de Pós-graduação Lato Sensu: em Produção de material Didático para EaD, em Gestão em Saúde, em Gestão Pública Municipal, em Gestão Pública; Licenciatura: Educação Física, em Artes Plásticas, Ciências Agrárias, em Biologia e Bacharelado: Administração e em Administração Pública;

- Abrangência: Todas as localidades do estado onde exista um polo da UFAM.

\subsubsection{Universidade do Estado do Amazonas (UEA)}

A Universidade do Estado do Amazonas fundada em 2001, iniciou o seu trabalho com educação a distância com o Curso de Normal Superior que atendeu todos os municípios do estado. Esse projeto foi nomeado como PROFORMAR. Hoje este projeto já foi concluído, porém muitas lições foram aprendidas

\footnotetext{
${ }^{3}$ http://www.tvufam.ufam.edu.br/
} 
e repassadas para outros cursos que hoje estão em andamento, como é o caso do curso de Tecnologia em Análise de Sistemas (TATIS). Para esse projeto, foi investigado o PROFORMAR, que serviu como modelo de educação a distância oferecido pela UEA.

Vale ressaltar que os cursos oferecidos não são regulares, isto é, não são oferecidos todos os anos. Em alguns casos são oferecidos somente para uma turma em cada cidade, para impedir o saturamento de profissionais e possibilitando que todas as cidades que tenham carência de qualificação sejam atendidas pelo programa.

O modo de ingresso é por meio do vestibular. Atualmente, esse processo atende 12 municípios. As ferramentas utilizadas são: TV convencional com receptor para assistir as aulas; plataforma Moodle para disponibilização dos conteúdos adicionais, fórum, dúvidas etc.

O curso é dividido em semestres da mesma forma que o presencial. Em cada disciplina ministrada, três professores são responsáveis pelas aulas, conteúdos, criação de um livro de apoio e acompanhamento dos alunos a distância. Cada polo possui um tutor formado na área de computação, que auxilia os alunos e cada um possui a seguinte infraestrutura: uma TV, um decodificador e um DVD player. Cada cidade possui Internet, porém o acesso é opcional por ser feito em lan house e fora do horário de aula.

As aulas são transmitidas, por TV satélite, diariamente em um horário fixo. Cada aluno as assiste na sala de aula do polo destinada para este fim. Para um aluno esclarecer uma dúvida, ele pode perguntar ao tutor presencial que é um profissional graduado na área principal do curso. Ou ainda perguntar para os professores especialistas da disciplina que se encontram na capital, ligando para um 0800 ou usando o fax. Assim, os professores recebem as dúvidas e podem respondê-las ao vivo.

Em uma classificação dessa instituição segundo os conceitos expostos no Capítulo 4, a educação a distância promovida pela UEA caracteriza-se da seguinte forma:

- Organização Administrativa: Finalidade Dupla;

- Geração de ensino: Segunda Geração;

- Regime de aprendizado: EaD misto;

- Tecnologias Utilizadas: AVA; DVD; livros didáticos;

- Ferramentas e equipamentos utilizados: AVA; 1 TV, 1 decodificador, 1 DVD player;

- Profissionais envolvidos: tutor presencial; professor; equipe de apoio pedagógico; 
- Nivel dos cursos: nível superior;

- Cursos oferecidos: Normal Superior, Educação Física, Tecnologia em Análise de Sistemas;

- Abrangência: varia de acordo com o curso oferecido, o Normal Superior chegou a ser oferecido em todas as cidades do estado.

\subsubsection{Centro de Educação Tecnológica do Amazonas (CETAM)}

O CETAM é uma autarquia vinculada à Secretaria de Ciência e Tecnologia que foi criada com o objetivo de promover a educação profissional no estado do Amazonas oferecendo cursos técnicos e tecnológicos. ${ }^{4}$ Ademais, essa autarquia está presente em Manaus e em 50 municípios do Estado do Amazonas, oferecendo cursos em diversas áreas do conhecimento. Os cursos oferecidos são tanto presencias quanto a distância. Os cursos oferecidos a distância são de responsabilidade da Escola de Educação a Distância do CETAM, ${ }^{5}$ que hoje, oferecem três cursos técnicos, que são: hospedagem, manutenção e suporte em informática, serviços públicos.

Em uma classificação dessa instituição segundo os conceitos expostos no Capítulo 4, a educação a distância promovida pelo CETAM caracteriza-se da seguinte forma:

- Organização Administrativa: Finalidade Dupla;

- Geração de ensino: Quinta Geração;

- Regime de aprendizado: EaD;

- Tecnologias Utilizadas: AVA; CD-ROM; livros didáticos;

- Ferramentas e equipamentos utilizados: AVA; Internet;

- Profissionais envolvidos: tutor presencial; tutor a distância; professor;

- Nível dos cursos: técnico;

- Cursos oferecidos: Turismo; Manutenção e suporte em computadores e Serviços Públicos;

- Abrangência: na capital e em 12 municípios do interior do estado - Barreirinha, Coari, Eirunepé, Itacoatiara, Maués, Nhamundá, Parintins, Presidente Figueiredo, Santa Izabel do Rio Negro, São Gabriel da Cachoeira, Tabatinga e Tefé.

\footnotetext{
${ }^{4}$ http://www.cetam.am.gov.br/

${ }^{5}$ http://ead.cetam.am.gov.br/portal/
} 


\subsubsection{Colégio Militar de Manaus (CMM)}

O Colégio Militar de Manaus iniciou suas atividades na capital do Amazonas no ano de 1972, sendo o oitavo fundado no Brasil. Desenvolve um projeto de EaD desde $2002,{ }^{6}$ que oferece ensino médio e fundamental aos dependentes dos militares em serviço que precisam residir em locais que não Manaus. Essa iniciativa visa não prejudicar os filhos de militares que atuam em regiões de fronteiras ou em missões em outros países. As Figuras 3.3 e 3.4 mostram onde o ensino do Colégio Militar de Manaus atua com o seu programa de educação a distância. Além dos diversos países em que há militares em missão, são atendidos pelo projeto os estados do Amazonas, Pará, Roraima, Acre, Rondônia e Amapá, com exceção das cidades de Manaus e Belém.

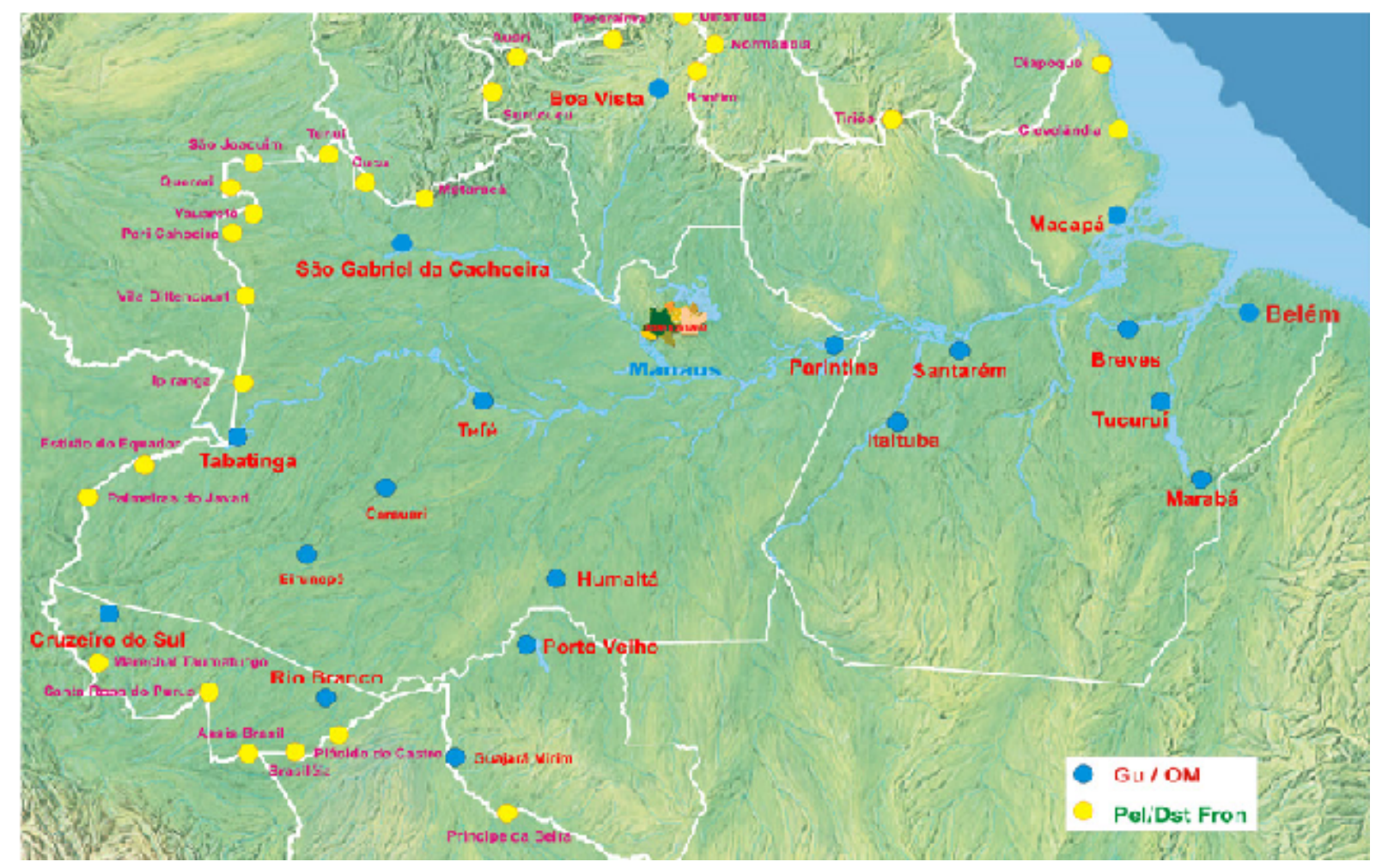

Figura 3.3: Localidades brasileiras onde os militares contam com o ensino do CMM a distância. Fonte: CMM

Em uma classificação dessa instituição segundo os conceitos expostos no Capítulo 4, a educação a distância promovida pelo CMM caracteriza-se da seguinte forma:

- Organização Administrativa: Finalidade Dupla;

- Geração de ensino: Quinta Geração;

- Regime de aprendizado: EaD - puro. As provas são feitas nos quartéis, com data e hora marcada e as demais atividades são feitas on-line de

\footnotetext{
${ }^{6}$ http://www.ead.cmm.ensino.eb.br/portal/
} 


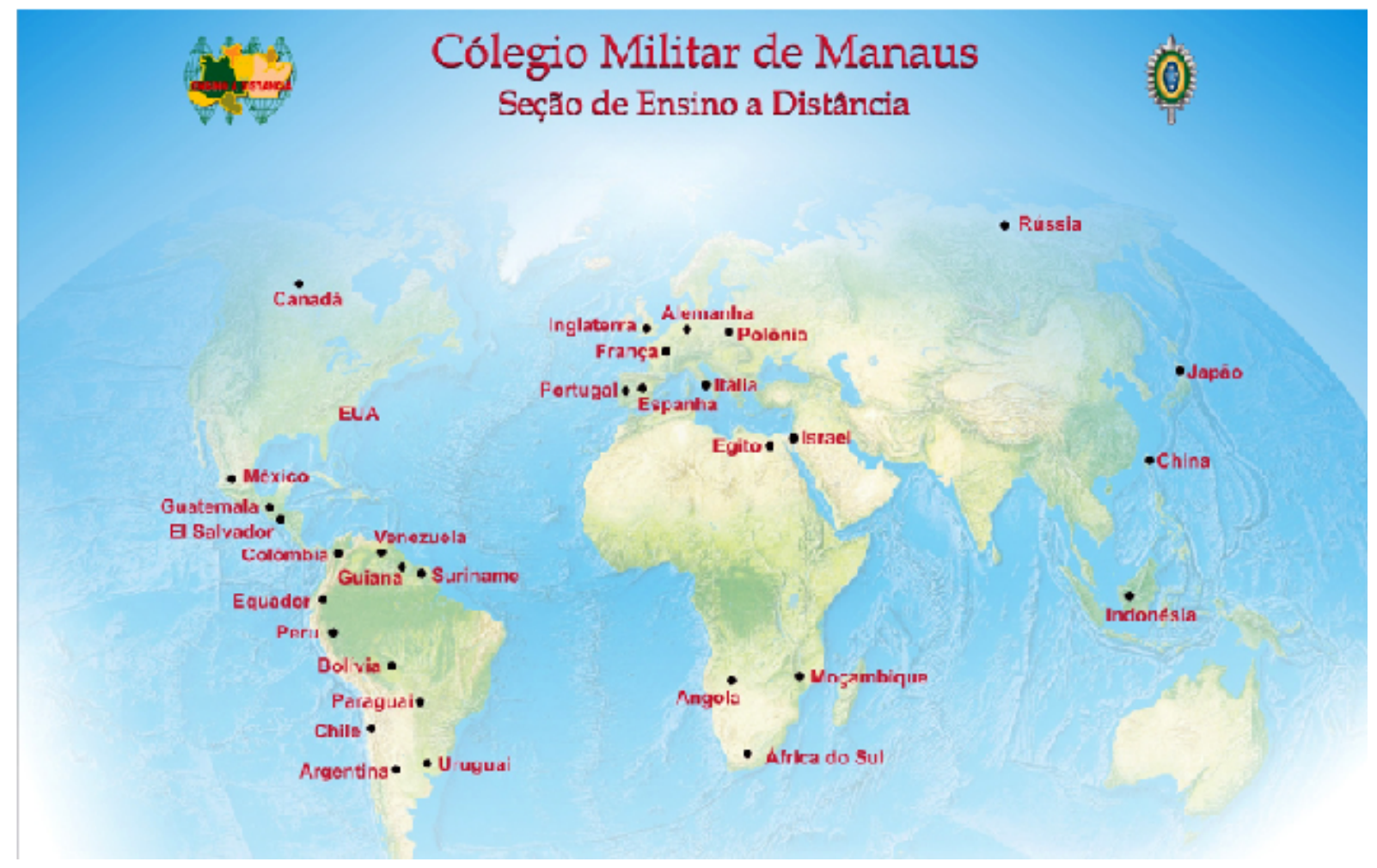

Figura 3.4: Países onde os militares contam com o ensino do CMM a distância. Fonte: CMM

acordo com a disponibilidade do aluno;

- Tecnologias Utilizadas: AVA; CD-ROM; livros didáticos;

- Ferramentas e equipamentos utilizados: AVA; Internet;

- Profissionais envolvidos: tutor virtual; professor;

- Nível dos cursos: ensino básico - fundamental e médio;

- Cursos oferecidos: $6^{\circ}$ e $9^{\circ}$ ano do Ensino Fundamental e as três séries do Ensino Médio;

- Abrangência: seis estados do Brasil e em 33 países, conforme as Figuras 3.3 e 3.4.

\subsubsection{Secretaria da Educação do estado do Amazonas (SEDUC- AM)}

No Amazonas existe uma grande demanda de educação básica no interior do estado, e uma grande dificuldade em atendê-la devido ao difícil acesso e também à falta de professores dispostos a residirem nas cidades que não a capital. Nesse contexto, a SEDUC-AM propôs um novo modelo para atender essa demanda específica, criando em 2007 o Centro de Mídias, encarregado de gerenciar os cursos a distância oferecidos. 
Esse centro implementou uma solução de Educação a Distância (EaD) disponibilizando aulas com transmissão via satélite. Esse projeto tem como objetivo solucionar o problema de 17 mil alunos do estado do Amazonas residentes nas comunidades rurais. Esses alunos estudavam normalmente somente até a $9^{a}$ série do ensino fundamental. Não davam sequência aos seus estudos por conta do difícil acesso e a falta de escolas. ${ }^{7}$

Os cursos a distância têm a mesma carga horária do ensino regular. Atualmente, chegam em 300 comunidades rurais, atendendo a um total de 1.500 comunidades em todo o Amazonas. ${ }^{8}$

O projeto do Amazonas utiliza o serviço HughesNet ${ }^{9}$ de banda larga via satélite, para transmitir aulas conduzidas diariamente da central de mídia na capital do estado, para alunos localizados no interior.

Em uma classificação dessa instituição segundo os conceitos expostos no Capítulo 4, a educação a distância promovida pela SEDUC-AM caracteriza-se da seguinte forma:

- Organização Administrativa: Finalidade Dupla;

- Geração de ensino: Quarta Geração - com vídeoconferência usando IPTV e 100\% interativa;

- Regime de aprendizado : EaD misto - possui horário e local fixo para a transmissão das aulas, porém o aluno poderá interagir de modo assíncrona ou síncrona fora do horário da aula utilizando a plataforma de ensino;

- Tecnologias Utilizadas: AVA; livros didáticos;

- Ferramentas e equipamentos utilizados: antena bidirecional para recebimento e envio da transmissão, um kit tecnológico, que inclui: computador, impressora, webcam, microfone, telefone ip, impressora, nobreak e um televisor LCD de 37";

- Profissionais envolvidos: tutor presencial; equipe de apoio pedagógico; professor; equipe de apoio de mídias (preparação do material, preparação das aulas em estúdio); equipe técnica para apoio e suporte as ferramentas utilizadas;

- Nível dos cursos: ensino básico;

- Cursos oferecidos: Ensino Médio e Ensino Fundamental;

- Abrangência: Todas as localidades do estado.

\footnotetext{
${ }^{7}$ http://www.centrodemidias.info/

${ }^{8}$ http://www.seduc.am.gov.br/noticia.php?cod=593

${ }^{9}$ http://www.hughesnet.com.br/
} 


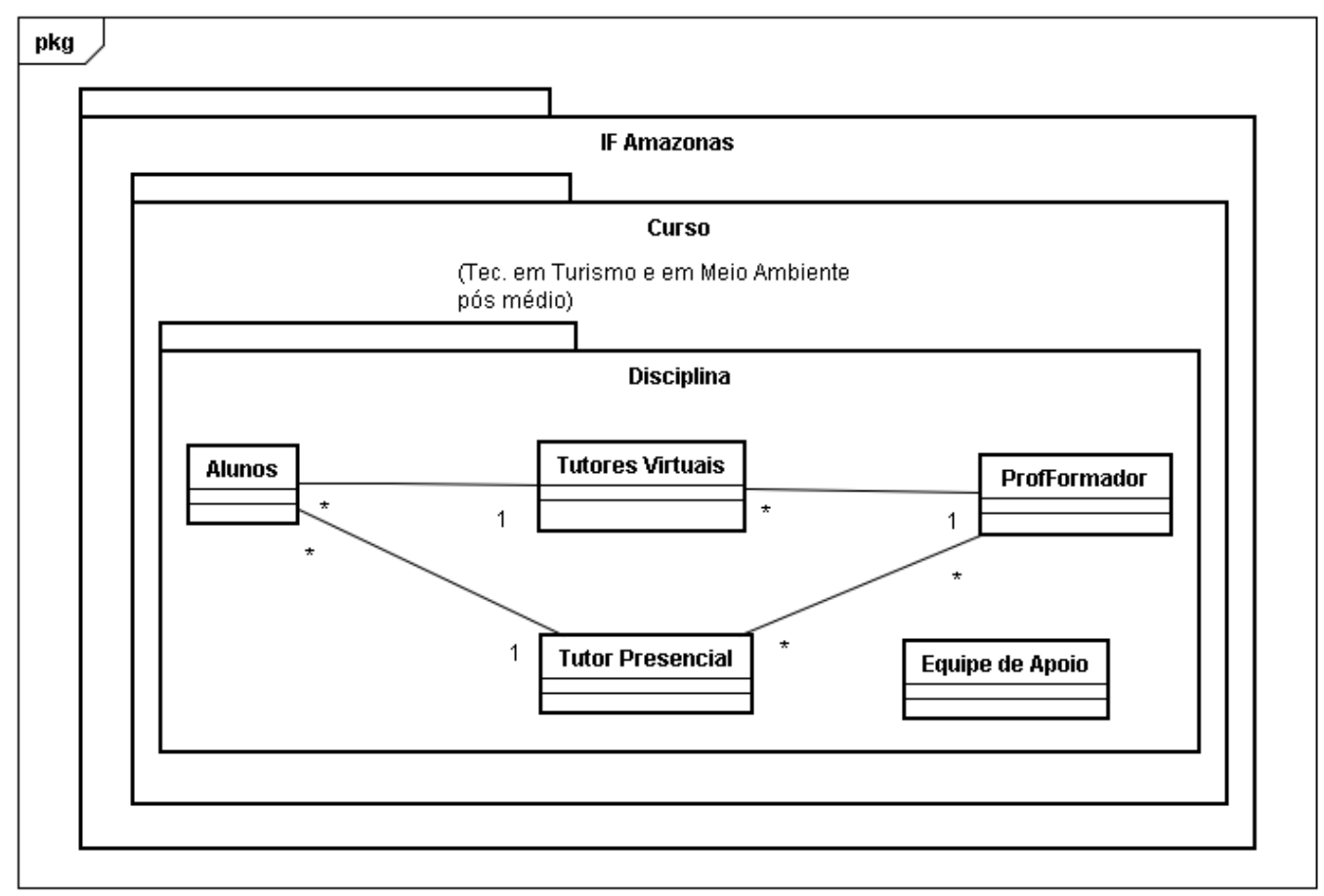

Figura 3.5: Estrutura de EaD do IFAM

\subsubsection{Instituto Federal do Amazonas (IFAM)}

O Instituto Federal de Educação, Ciência e Tecnologia do Amazonas IFAM, ${ }^{10}$ oferece cursos de nível médio, técnico, tecnológico, especialização e mestrado.

O Departamento de Educação a Distância ${ }^{11}$ iniciou suas atividades em 2009 e no primeiro semestre de 2010 ofereceu os primeiros cursos técnicos nessa modalidade para a capital e interior do estado. Esse projeto faz uso do LMS Moodle, por meio dele são disponibilizados todo o conteúdo das aulas e são feitas as atividades individuais e em grupo. As dúvidas podem ser esclarecidas usando as ferramentas de comunicação do ambiente virtual e são respondida pelos tutores virtuais.

A infraestrutura dos centros é: sala de aula, biblioteca, secretária local, tutor local, laboratório de informática, com uma Internet com velocidade mínima de 540kbps. Os centros (polos) são instituições de ensino municipais ou estaduais. Em cada disciplina estão matriculados, em média, 40 alunos.

Em uma classificação dessa instituição segundo os conceitos expostos no Capítulo 4, a educação a distância promovida pelo IFAM caracteriza-se da seguinte forma:

- Organização Administrativa: Finalidade Dupla;

- Geração de ensino: Quinta Geração;

\footnotetext{
${ }^{10}$ http://www.ifam.edu.br/

${ }^{11}$ http://ead.ifam.edu.br/
} 


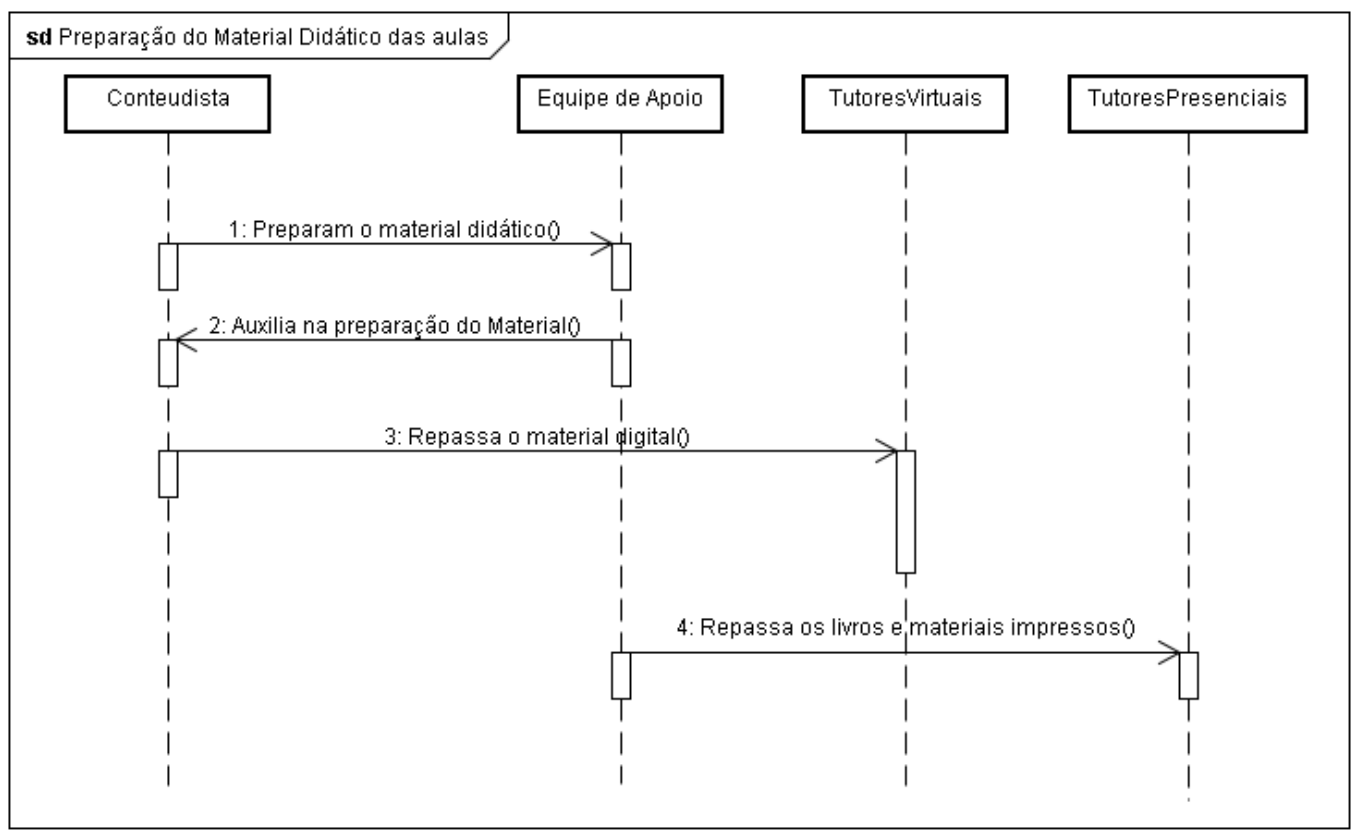

Figura 3.6: Diagrama de sequencia da preparação dos materiais didáticos no IFAM.

- Regime de aprendizado: EaD puro. Existe polos de apoio nas cidades, porém o aluno faz o seu horário;

- Tecnologias Utilizadas: AVA; livros didáticos;

- Ferramentas e equipamentos utilizados: AVA; Internet;

- Profissionais envolvidos: tutor presencial; tutor a distância; professor (conteudista);

- Nível dos cursos: nível técnico;

- Cursos oferecidos: Meio Ambiente e Turismo;

- Abrangência: Nas cidades: Barreirinha, Eirunepé, Manaus, Tabatinga e Tefé.

A Figura 3.5 descreve a estrutura administrativa do IFAM. O IFAM possui um núcleo de EaD que gerencia os cursos de Turismo e Meio Ambiente. Cada curso contém diversas disciplinas e cada disciplina possui um professor formador que é responsável pela preparação do conteúdo e material das avaliações. Cada polo possui inúmeros alunos que contam com um tutor virtual por disciplina e um tutor presencial por polo. O tutor presencial pode entrar em contato com vários professores formadores de acordo com a quantidade de disciplinas que o curso oferece. Cada curso conta com uma equipe de apoio para o suporte técnico e de preparação do material para a plataforma. 


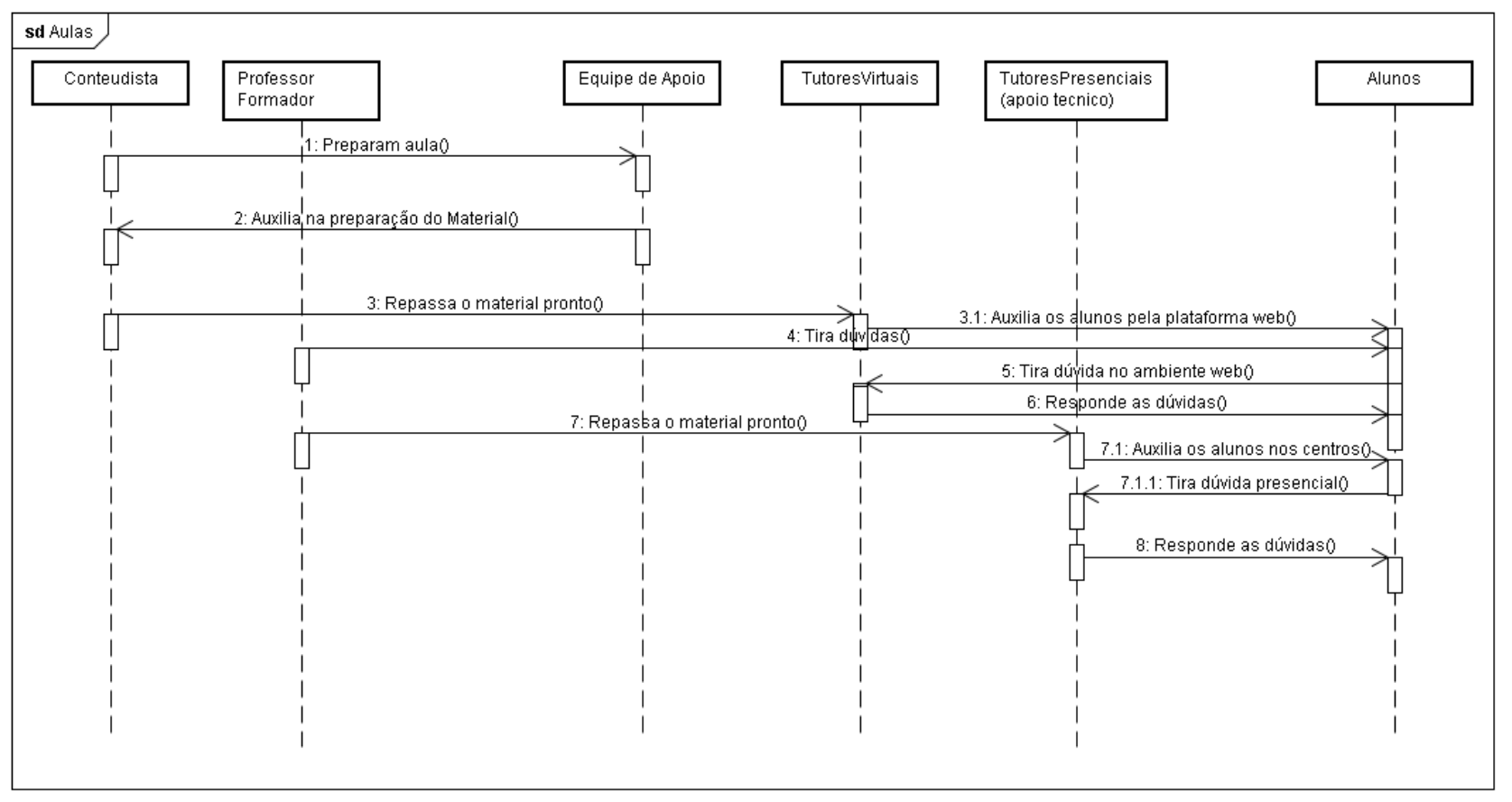

Figura 3.7: Diagrama de sequência da dinâmica de aula no IFAM.

A Figura 3.6 descreve quem são as pessoas envolvidas na preparação do material didático, tanto o impresso quanto o digital, mostrando o papel do conteudista, professor formador, equipe técnica, tutores virtuais e tutores presenciais e o relacionamento entre eles na criação das apostilas que serão enviadas aos alunos.

A Figura 3.7 descreve como acontece uma aula no IFAM, apresentando os atores envolvidos e quais as suas funções no dia a dia dos estudantes.

A Figura 3.8 descreve como é elaborada uma avaliação para ser aplicada presencialmente nos polos onde são oferecidos os cursos, com isso, é possível observar que o professor formador está envolvido nesse processo desde a criação da avaliação até a correção final, tendo como apoio os tutores virtuais, para esclarecer dúvidas dos alunos e tutores presencias que aplicação as atividades pessoalmente.

\subsubsection{Considerações sobre os projetos}

Após a análise das principais iniciativas de educação a distância no estado do Amazonas foi possível verificar quais as principais vantagens - o que podemos usar de lição aprendida - e as desvantagens - pontos que podem ser melhorados.

A Tabela 3.4 apresenta as características de cada projeto apresentado nesse Capítulo. 


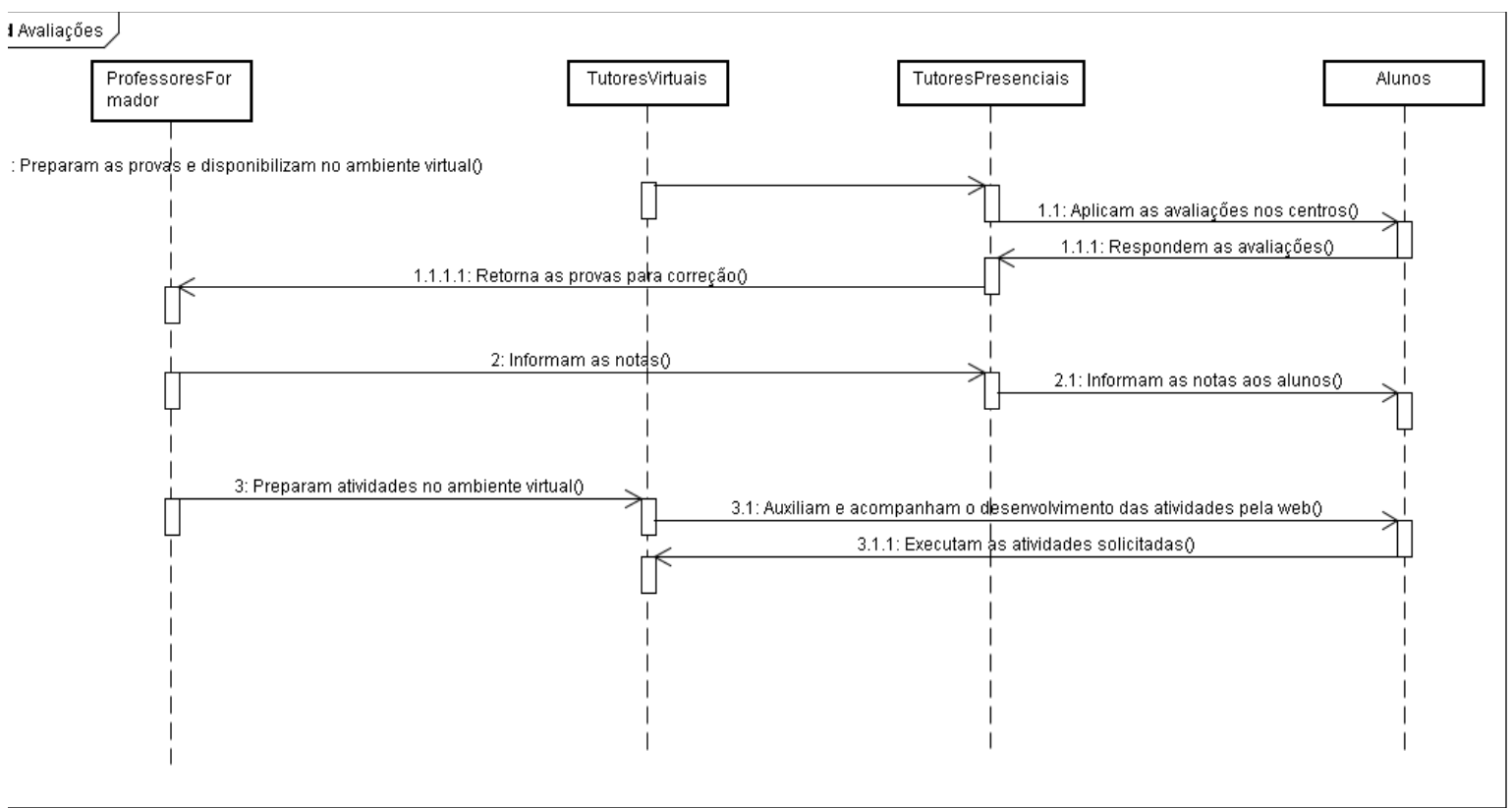

Figura 3.8: Diagrama de sequência do processo de avaliação no IFAM.

Tabela 3.4: Características das instituições pesquisadas.

\begin{tabular}{|c|c|c|c|}
\hline Instituiç̧ão & Vantagens & Desvantagens & Observações \\
\hline UFAM & $\begin{array}{l}\text { Garante que em cada ci- } \\
\text { dade que é oferecido o } \\
\text { curso tenha um polo de } \\
\text { apoio com Internet para os } \\
\text { alunos matriculados. }\end{array}$ & $\begin{array}{l}\text { É } 100 \% \text { Web e em cidades } \\
\text { onde a Internet não é boa, } \\
\text { não é possível oferecer os } \\
\text { cursos. }\end{array}$ & \\
\hline UEA & $\begin{array}{l}\text { As aulas televisivas tem um } \\
\text { custo baixo para cada polo } \\
\text { e consegue atender todas } \\
\text { as cidades do estado. }\end{array}$ & $\begin{array}{l}\text { Não existe interatividade e } \\
\text { as dúvidas são tiradas efe- } \\
\text { tuando ligações para um } \\
\text { número } 0800 \text { disponibili- } \\
\text { zado pela instituição, por } \\
\text { meio do uso do fax ou do } \\
\text { uso de e-mail em lan hou- } \\
\text { ses da cidade. }\end{array}$ & $\begin{array}{l}\text { A UEA já está em processo } \\
\text { de transição para o uso da } \\
\text { tecnologia IP-TV, nos mol- } \\
\text { des de ensino da SEDUC- } \\
\text { AM. }\end{array}$ \\
\hline CETAM & $\begin{array}{l}\text { Garante que em cada ci- } \\
\text { dade que é oferecido o } \\
\text { curso tenha um polo de } \\
\text { apoio com Internet para os } \\
\text { alunos matriculados. }\end{array}$ & $\begin{array}{l}\text { É } 100 \% \text { Web. Em cidades } \\
\text { onde a Internet não é boa } \\
\text { não é possível oferecer os } \\
\text { cursos. }\end{array}$ & \\
\hline CMM & $\begin{array}{l}\text { Garante que todos os mili- } \\
\text { tares tenham acesso a In- } \\
\text { ternet que possibilite os } \\
\text { estudos de seus dependen- } \\
\text { tes. }\end{array}$ & $\begin{array}{l}\text { As provas são feitas nos } \\
\text { quartéis mais próximos e } \\
\text { as dúvidas que não conse- } \\
\text { guem ser esclarecidas on } \\
\text { line também. Isso pode de- } \\
\text { morar muito, para um aluno } \\
\text { de ensino básico. }\end{array}$ & $\begin{array}{l}\text { O sucesso deste curso } \\
\text { deve-se ao regime militar } \\
\text { que preza a disciplina de } \\
\text { horários e tarefas, sendo } \\
\text { possível esse projeto ser } \\
\text { positivo mesmo com crian- } \\
\text { ças e adolescente. }\end{array}$ \\
\hline
\end{tabular}


Tabela 3.4: Características das instituições pesquisadas (continuação)

\begin{tabular}{|l|l|l|l|}
\hline Instituição & Vantagens & Desvantagens & Observações \\
\hline SEDUC-AM & $\begin{array}{l}\text { Possibilita interatividade } \\
\text { total, possui alta quali- } \\
\text { dade de áudio e vídeo por } \\
\text { meio do uso da tecnologia } \\
\text { IP-TV }\end{array}$ & $\begin{array}{l}\text { Utiliza uma plataforma } \\
\text { proprietária e definida por } \\
\text { meio de licitação. Limi- } \\
\text { tando o desenvolvimento } \\
\text { da plataforma. }\end{array}$ & $\begin{array}{l}\text { Seu projeto é reconhecido } \\
\text { nacional e internacional- } \\
\text { mente, como prova disso os } \\
\text { inúmeros prêmios ganhos. }\end{array}$ \\
\hline IFAM & $\begin{array}{l}\text { Garante que em cada ci- } \\
\text { dade que é oferecido o } 100 \% \text { Web. Em cidades } \\
\text { curso tenha um polo de } \\
\text { apoio com Internet para os } \\
\text { alunos matriculados. }\end{array}$ & $\begin{array}{l}\text { não é possível oferecer os } \\
\text { cursos. }\end{array}$ & $\begin{array}{l}\text { poto inicia suas ati- } \\
\text { vidades no ano de 2010, } \\
\text { subsídios para uma análise } \\
\text { mais detalhada em condi- } \\
\text { ções reais. }\end{array}$ \\
\hline
\end{tabular}

\subsection{Escolha do projeto para estudo de caso}

O projeto escolhido para estudo de caso foi o do IFAM, por ser um curso $100 \%$ Web e, após o levantamento efetuado, percebe-se que esse modelo poderá ter inúmeros problemas devido à qualidade da Internet quando for expandida para as demais cidades do estado, por não contar com uma infraestrutura como a da Seduc que conta com uma Internet dedicada para os cursos a distância. Esse projeto tem como objetivo, então, estudar alternativas para contornar a infraestrutura existente através de recursos de softwares. Assim, existe grande potencial para pesquisas cujo objetivo seja contribuir para a aproximação entre os alunos e os professores. Devido a carência de pesquisas na área, este projeto obteve total suporte por parte da instituição para o desenvolvimento desta pesquisa.

\subsection{Relatos}

No trabalho de Agner (2007) é utilizada a técnica de história oral como uma ferramenta para obter dados que não se encontram registrados em documentos, e conclui que essa técnica pode ser útil quando usada para investigação na área de Interação Humano-Computador. Sua afirmação é reforçada por autores como Alberti (2004), que define história oral como uma técnica de pesquisa. Já Cervo e Bervian (2002) aconselham o seu uso e descrevem a importância dessa técnica como fonte de dados de fatos que não podem encontrar registros ou fontes documentais, mas pode ser relatados por pessoas 
que viveram a realidade estudada. Esse método correponde ao estudo a respeito de um fato a partir de relatos dos envolvidos com o fato.

Foram entrevistadas duas pessoas que estão diretamente envolvidas com o processo de educação a distância na Instituição do IFAM, eles são: R. L., que é o coordenador do Núcleo de Ensino a Distância do IFAM, e o professor R. C., que é professor de disciplinas nos cursos a distâncias oferecidos pelo IFAM.

O objetivo foi levantar dados a respeito das experiências do dia a dia de um curso a distância no estado do Amazonas, identificando as dificuldades encontradas e quais as soluções adotadas. Também foram discutidas quais possibilidades de mudanças que, na visão dos entrevistados, poderiam melhorar a qualidade dos cursos oferecidos. Os resultados das entrevistas são apresentados a seguir.

Ao professor Roceli Lima foram realizadas algumas perguntas:

1. Como é uma aula? Terá um tutor em cada turma para auxiliar o acompanhamento da turma na disciplina? "As aulas são via Internet e por meio de Material Impresso. O desenvolvimento das aulas são acompanhado por três profissionais: o tutor a distância (que atua como orientador/motivador/monitorador das atividades online), tutor presencial (atua da mesma forma no polo EaD e aplicará as avaliações bimestrais) e tutor formador (atua como avaliador, facilitador na aprendizagem)."

2. Como é a Internet nessas cidades que são polos dos cursos oferecidos pelo IFAM? "A melhor conexão é via satélite de $512 \mathrm{mbps}$ a pior é a discada que permite acesso de no máximo 54kbps."

3. Quais são as maiores dificuldades que você acredita que precisa solucionar? "Qualidade do material impresso para diminuir as dificuldades de acesso ao material online."

4. Como é feita a transmissão das aulas? "Via Internet e impressa."

5. Como são realizadas as provas? "Presencialmente"

6. Existe o conceito de conselho de classe? Se sim, como é feito? "Sim. Da mesma forma que acorre no modelo tradicional de ensino."

7. Para materiais adicionais, montados no decorrer do curso, como é entregue aos alunos? "Via correios (impresso) ou via Internet"

8. Quem são os tutores presenciais? Quais suas qualificações? É o mesmo nas diferentes disciplinas? "Tutores presenciais são bolsistas, com no mínimo graduação em qualquer área. Este profissional atuará na orientação operacional do sistema AVA de qualquer disciplina. Este profissional não corrigirá trabalhos ou qualquer outra atividade acadêmica." 
9. Como são os centros? Quantos alunos por disciplina (em média)? "Os centros (polos) serão instituições de ensino Municipal ou Estadual. Em média serão 40 alunos por disciplina."

10. Como é feito o processo de seleção dos alunos? E qual a periodicidade? "Usará o mesmo processo de seleção para o ensino tradicional. Periodicidade também igual, que neste momento será semestral."

11. Qual é a infraestrutura (equipamentos) dos polos? "Sala de aula. Biblioteca. Secretária local. Tutor local. Laboratório de informática. Internet banda larga com no mínimo 540kbps."

12. Existem atividades colaborativas? Ou é sempre professor-aluno? "Sim. Trabalhos em grupo. Fórum."

Uma entrevista também foi realizada com o professor Msc. Ricardo Câmara, que é mestre em Ciências da Computação pela UFAM e atua como professor presencial e a distância nos cursos oferecidos pelo IFAM.

1. Quais as ferramentas que são utilizadas no ambiente Moodle? "Atividades valendo nota como fórum e materiais adicionais. (...)O chat, já tentei utilizar, porém não consegui reunir os alunos e garantir que todos estivessem conectados ao mesmo tempo."(...) "O Moodle poderia ser mais utilizado (não é mais devido a qualidade de conexão)"

2. Qual polo é o melhor em termos de infraestrutura? "O polo de Eirunepé é um dos melhores em relação à qualidade de Internet e de equipamentos"

3. Como você prepara o material para os alunos? "São feitas apostilas e enviadas impressas ou colocadas no ambiente para download"

4. Na sua opinião, quais são as principais dificuldades da EaD aqui no Amazonas? "A geografia. Tudo é muito distante e a Internet é difícil. Temos também grandes dificuldades em relação a logística, contratar transportadoras, enviar por barco ..."

5. Há outra ferramenta que você conheça e poderia ser utilizada em conjunto com o Moodle para auxiliar nas aulas? "Não conheço, até porque na nossa realidade é difícil uma que funcione."

Após as entrevistas, foi possível observar que o grande desafio da educação a distância é a qualidade da Internet. Para tentar contornar essa dificuldade são executadas iniciativas como a criação de material didático auxiliar impresso que são enviados aos polos para cada aluno. Um fato que foi constatado também é que o material impresso, sendo enviado por meio dos correios 
ou transportadoras particulares, demora muito tempo para chegar aos alunos. No caso de Eirunepé, segundo informações dos Correios ${ }^{12}$ uma encomenda demora cerca de 45 dias para ser entregue, saindo de Manaus. Devido a isso, é necessário um planejamento muito grande de logística a fim de que todos os materiais sejam entregues antes de iniciar as disciplinas. Fato que nem sempre ocorre, devido a inúmeros problemas como grandes secas nos rios da região, greves dos correios, etc. Esse atraso na entrega dos materiais causa inúmeros transtornos para os alunos, que chegam a ter prova sem ter em mãos o conteúdo completo da disciplina conforme foi constatado em conversa com os alunos do IFAM de Eirunepé.

Guando não é possível enviar o material impresso dentro do prazo mínimo necessário, é enviado aos alunos pela plataforma Web. O arquivo em que o conteúdo é disponibilizado precisa ter um tamanho pequeno para ser possível fazer o download pelo tutor do polo e em seguida ser distribuído para os alunos. Para atender a esse requisito de tamanho de arquivo, os professores são orientados a prepararem uma apostila que tenha o mínimo de figuras possível, sendo muitas vezes somente texto.

\subsection{Considerações Finais}

Após esse levantamento sobre os projetos desenvolvidos no estado so Amazonas e a escolha do projeto que seria cenário da pesquisa, estudou-se a respeito do que já foi desenvolvido em relação a educação a distância e a TV Digital. Para posteriormente aplicar o LMS escolhido no cenário do IFAM, levando em consideração as suas limitações e características.

\footnotetext{
${ }^{12}$ Informações disponíveis no site oficial: http://www.correios.com.br/
} 


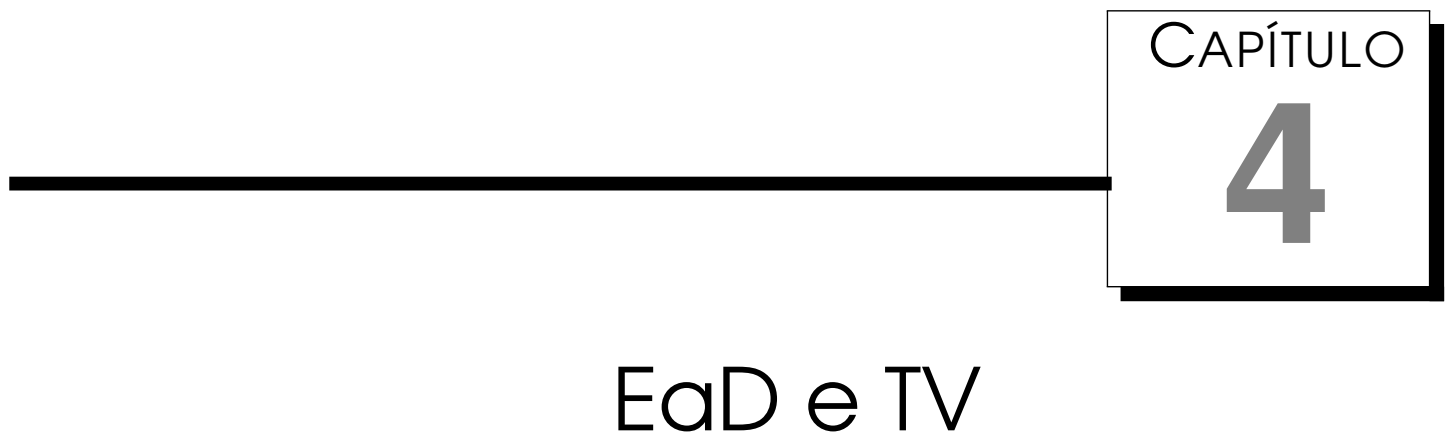

Após o levantamento dos projetos desenvolvidos no estado do Amazonas, observou-se que vários trabalhos obtiveram sucesso ao utilizar a TV como ferramenta de comunicação entre professores e alunos. Foi observado também que atualmente é indispensável o uso de um LMS como centralizador de informações a respeito do curso e como canal de comunicação entre equipe de apoio, professores e alunos.

Este Capítulo apresenta uma revisão bibliográfica, em temas de educação a distância e das tecnologias audiovisuais interativas. São analisados e discutidos alguns trabalhos que serviram para evidenciar o estado da arte e obter parâmetros para o desenvolvimento do projeto.

\subsection{EaD e padrões de conteúdo}

Diversos esforços de pesquisa em "aprendizado eletrônico"têm levado ao desenvolvimento de ferramentas acessíveis em diversas situações, de forma que se possa aprender em qualquer lugar, a qualquer momento, conforme afirmam Prakash et al. (1999) e Saleemi et al. (2008).

Para atender a essa tendência é necessário a padronização dos conteúdos disponibilizados em cursos de EaD. Diversos esforços em pesquisa e padronização têm sido empreendidos. Alguns grupos como o IMS Global Learning Consortium, Advanced Distributed Learning (ADL), IEEE Learning Technology Standards Committee e Dublin Core destacam-se por suas especificações que visam formalizar padrões de conteúdos educativos. Esses padrões surgiram devido a necessidade de um modelo que fosse capaz de organizar os conteúdo para que possa ser reaproveitado e compartilhado. 
Segundo Belda (2009), a Educational Modelling Language (EML) foi especificada a partir de uma conjunto de sistemas de notação com implementação baseadas em XML (Extensible Markup Language). Esse padrão facilita a descrição dos dados e suas relações. Esses dados são unidades de estudo que podem conter texto, exercícios, vídeos, etc, e as descrições das atividades dos alunos e professores envolvidos nesse processo de aprendizagem, conforme mencionam Hermans et al. (2003).

Segundo Koper e Manderveld (2004) o padrão IMS Learning Design Information Model, estabelece um modelo para conteúdo provenientes de ambientes de aprendizagem. Esse modelo possui três componentes básicos: um modelo conceitual (que define vocabulário e relações funcionais entre conceitos) um modelo informacional (que restringe o modelo conceitual e descreve elementos para diferentes níveis de implementação) e um modelo comportamental (que descreve estados a serem implementados pelo sistema em função das atividades).

Em relação à especificação dos conteúdos educacionais em forma digital, um avanço importante são os modelos de objetos de aprendizagem (learning objects). Objetos de aprendizagem são unidades autocontidas e reusáveis de conteúdo educacional que podem ser combinadas para constituir cursos em diferentes contextos, conforme é mencionado por Wiley (2001). Em geral, objetos de aprendizagem são constituídos por uma agregação de objetos multimídia, de modelos de navegação, de recursos de avaliação e de metadados descritivos. Segundo Al-Khalifa e Davis (2006), os objetos de aprendizagem são constituídos por objetos multimídia que são agregados em conjunto com artefatos complementares. O resultado da agregação é um pacote que é instalado no ambiente de aprendizagem, o qual deverá desempacotar e fornecer uma apresentação multimídia dos conteúdos ao usuário. Do ponto de vista de padronização, as principais iniciativas relacionadas a objetos de aprendizagem são IEEE-LOM, IMS-CP e SCORM, englobando desde as descrições dos metadados a formas de empacotamento e reprodução nos LMS, conforme comenta Polsani (2003). Uma característica presente em todos esses padrões é o uso de vocabulários em XML como formalismo de modelagem dos conteúdos.

Nota-se, também, como resultados desses esforços, a disseminação de infraestruturas especializadas, envolvendo Ambientes de Aprendizado Eletrônico (LMS; e.g. Tidia-AE, Moodle), com funcionalidades para gerência e colaboração dos atores do processo ensino - aprendizagem e para manutenção dos conteúdos educacionais.

Os esforços de padronização também têm incluído preocupações como problemas de acessibilidade e adaptabilidade de conteúdos audiovisuais interativos. Anido-Rifón (2008) apresenta uma especificação que contempla essa 
preocupação com a acessibilidade e a convergência de tecnologias. O autor apoia-se em referências de acessibilidade propostas pelo IMS Global Learning Consortium, tais como ACCLIP (Accessibility for Learner Information Package), que descreve formas possíveis de interação entre estudantes dentro de um ambiente virtual de aprendizagem conforme suas preferências e interesses, a IMS Specification e ACCMD (Accessibity MetaData), que especificam metadados para a entrega de conteúdos associados a esses ambientes, IMS.

\subsection{A TV e a educação}

A TV é uma ferramenta explorada na difusão de conhecimento e de programas educativos. Segundo Moore e Kearley (2008), essa tecnologia caracteriza a segunda fase da educação a distância, nos Estados Unidos essa fase teve início em 1934. Já no Brasil, foi criada na década de 70 a TV Brasil (a princípio chamada Televisão Educativa, posteriormente mudou para TVE e hoje é conhecida como TV Brasil) que gera produções de grupos acadêmicos e independentes, sobretudo na forma de documentários e vídeo-reportagens voltados à produção colaborativa e comunitária.

Outras iniciativas privadas seguem a mesma proposta, que é disponibilizar material instrutivo de qualidade para a grande parcela da população brasileira que tem acesso à TV, sendo este um recurso acessivel à grande maioria da população . Uma programação que obteve destaque foi o Telecurso 2000 (Marinho, 2011) e algumas emissoras que transmitem materiais educativos em sua programação são: a TV Cultura (Cultura) e o Canal Futura (Futura).

Segundo Belda (2009) a ABTU (Associação Brasileira de Televisão Universitária) ${ }^{1}$ elaborou uma carta de princípios que afirma que as emissoras de TV têm um: "compromisso com a produção de conteúdo voltado para a educação, a promoção da cultura e do desenvolvimento regional e prestação de serviços, constituindo-se também em um espaço para a pesquisa e experimentação de novas linguagens, formatos e narrativas". Porém, a Internet tem tomado o lugar da TV como ferramenta de apoio a aprendizagem, propiciando maiores facilidades para experimentos na área da educação por ser mais acessível e menos custosa. Talvez pela TV ser uma ferramenta de uso coletivo seja melhor aplicada a métodos de educação menos formal, como é o caso de documentários e conforme afirmam Chorianopoulos e Lekakos (2007), enquanto os computadores de uso pessoal seriam mais propícios a práticas formais de educação.

\footnotetext{
${ }^{1}$ Disponivel em: http://www.abtu.org.br
} 


\subsection{A TVDi e a educação}

A união de tecnologias como TV, PC e Web possibilitam ao usuário a personalização do ambiente de estudo por meio da combinação entre eles, aproveitando o melhor da cada uma quanto a capacidade de reprodução de conteúdos multimídias, conforme afirma Lytras (2002). A TV apresenta-se como mais uma possibilidade de oferecer um ambiente de suporte a educação e a sua união com a Internet ou outras tecnologias podem motivar alunos e professores. A TV Digital Interativa pode enquadrar-se nesse cenário, explorando possibilidades de interação e de apresentação multimídia. Lytras (2002) aponta esse mercado em potencial que surge com a TVDi aplicada no cenário de educação, sendo conhecido como t-learning.

A TV é um eletrodoméstico que atinge a maior parte da população brasileira chegando a estar presente a 98\%, segundos dados do IBGE. Já a Internet encontra-se em apenas $17 \%$ da população, segundo dados do IBGE. Esses dados enfatizam a capacidade de acesso da TV, no Brasil. Autores como Trindade e de Abreu (1999) e Damásio (2003) afirmam que a TVDi poderá ter altos índices de aceitação como os existentes para TV analógica. Porém, esses dados ressaltam também que o uso do canal de retorno será restrito a uma pequena parcela da população, conforme observam Montez e Becker (2005).

No levantamento realizado observou-se algumas definições referentes ao termo "t-learning". Bellotti et al. (2006), referem-se de uma forma mais ampla, ao acesso a materiais de aprendizagem ricos em vídeo, apresentado em uma TV. Já Disessa (2000) refere-se à expressão t-learning como a união entre a TVDi e o uso de tecnologia computacional para suportar treinamento e atividades educacionais, o já conhecido e-learning. Complementando essa definição, pode-se considerar também a convergência entre TV e tecnologia computacional, como as aplicações interativas no ambiente de TVDi, para apoiar atividades educacionais.

Chorianopoulos e Lekakos (2007) defendem as vantagens da TVDi utilizando abordagens baseadas em e-learning. Em particular, o conceito de edutainment (educação como forma de entretenimento), com base no argumento de que as experiências dos usuários com a TV são historicamente ligadas às atividades de entretenimento. Assim, a concepção de experiências de aprendizagem para TVDi preferencialmente devem ser direcionadas para a aprendizagem informal por meio de conteúdos de valor agregado acrescentado interatividade associada ao programa principal. Na verdade, o foco no edutainment como complemento tem sido um tema recorrente, mas ao mesmo tempo muito foco tem sido direcionado sobre os quadros tecnológicos (Colace et al., 2008.; Pazos-Arias et al., 2008; Bellotti et al., 2008) e aplicações específicas (Costa e 
Lucena Jr., 2008; dos Santos et al., 2007), e a interação entre o usuário e os aplicativos educacionais não tem sido pensada tão sistematicamente.

Algumas iniciativas de aplicações interativas que exploram os recursos da TVDi com finalidade de aprendizagem já são exploradas por emissoras de TV, como por exemplo a BBC (BBC). Projetos acadêmicos também se encontram em desenvolvimento nos demais centros de pesquisa do país, contribuindo assim com a evolução dessa área no Brasil, conforme afirma Tonieto (2006). Visando a aprendizagem, a disponibilidade de documentos educacionais em TVDi permite experiências em situações de educação informal e permanente e, essas experiências, podem ser interligadas e contextualizadas no cotidiano do aluno com o envolvimento de canais de acesso não-convencionais (como TVDi) especializada em e-learning e t-learning (Aarreniemi-Jokipelto e Paivi, 2007; Colace et al., 2008.).

Diversos aplicativos para EaD em TVDi são relatados por dos Santos et al. (2007), dentre os quais incluem-se jogos interativos e questionários acionados por ícone de interatividade durante a programação. Um argumento importante desse trabalho é a oferta de conteúdos educacionais como complemento de valor agregado à programação televisiva. Observações semelhantes são apontadas por Al-Khalifa e Davis (2006) e Santos (2007). Em particular, Santos diferencia os níveis de interatividade (local, parcial e total) em função do grau de disponibilidade de canal de retorno.

Nessa direção, a disponibilização de conteúdos educacionais em ambientes de TVDi habilita experiências de aprendizado em situações não-formais e de educação continuada, que podem ocorrer no ambiente doméstico ou em ambientes institucionais, mediadas inclusive por dispositivos móveis e contextualizadas no cotidiano do aluno, conforme comentam Carliner e Shank (2008) e de J. L. Gomes e Sousa (2009).

\subsection{Focos de desenvolvimento em t-learning}

O estado da arte a cerca dos processos de concepção de produtos para TVD apresenta os principais desafios da criação de produtos de software para essa plataforma. Ainda não há um consenso sobre as funcionalidades necessárias para satisfazer os requisitos e desejos dos usuários, dado que são produtos ainda pouco familiares a designers e usuários. Um desses fatores críticos é a existência de poucos produtos similares que possam ser usados como benchmarking. Assim, o projeto corre o risco de começar sem um direcionamento claro a respeito das definições do produto, conforme comenta Eronen (2004).

Existem diferentes enfoques do desenvolvimento de serviços educacionais em TVDi, exemplificando alguma delas, baseado em Andreata (2006): 
- Educação informal ou programas educativos e canais temáticos - seriam programas de conteúdo educativo, porém sem preocupação com um conteúdo programático. No caso de canais temáticos, seriam emissoras que produziriam materiais específicos, como acontece na TV a cabo ( History Channel, National Geografic, etc). Exemplos desse material seriam documentários ou programas de perguntas e respostas que levariam até o usuário conteúdos educativos sobre cultura geral ou específica sem delimitar público alvo específico e nem requisitos prévios. Pode haver a interação do usuário por meio de participação em enquetes, quiz, etc. Não é mandatório o uso de canal de retorno.

- Serviço de apoio ao professor em sala de aula - serviço que fornece, utilizando um receptor de TVDi em sala de aula, conteúdo multimídia de apoio ao professor. Material multimídia com informações adicionais e interatividade local, como perguntas e respostas. Pataca et al. (2003) retrata a necessidade de existir um canal de TVDi público com programação específica e tecnologia que possibilite a busca da mesma, e a repetição do conteúdo, utilizando receptores com armazenagem de informação. Nesse modelo também não é mandatório o uso de um canal de retorno.

- Serviços de apoio ao estudante em casa - fornece a possibilidade de acesso pelo aluno ao material extraclasse, multimídia e enriquecido de interatividade permitindo maior fixação dos tópicos aprendidos, utilizando um set-top-box na casa do aluno e um canal local ou mantido por um grupo de escolas com currículo similar,. Um exemplo seria usar a TV UFAM, ${ }^{2}$ quando convertida para digital, passar a disponibilizar formas de comunicação assíncrona entre alunos e professores. Nesse formato só seria obrigatório o uso de um canal de retorno caso fossem utilizados softwares síncronos, todavia poderia ser explorada a interatividade local - sem canal de retorno.

- Serviços de interação pais-escola - fornece serviços para os pais acessarem informações e se comunicarem com a escola, como acesso a bases de dados escolares, notas e frequência, comunicações assíncronas como correio eletrônico e fórum de discussões e, ainda, comunicações síncronas como salas de bate papo para busca de informações imediatas com pessoas disponíveis nas escolas. Nesse modelo é mandatório o uso de canal de retorno.

- Conhecimentos específicos por meio de serviços interativos em canais independentes - redes comerciais podem oferecer serviços interativos em

\footnotetext{
${ }^{2} \mathrm{TV}$ da Universidade Federal do Amazonas - Informações disponíveis no site http://www.tvufam.ufam.edu.br/
} 
canais independentes de acordo com currículos de ensino nacionais ou recursos específicos como enciclopédias on-line. Nesse modelo também é mandatório o uso de canal de retorno, para poder enviar informações de compra para a operadora de serviços.

- Serviços de aprendizado em vídeos sob demanda - existe um mercado potencial de vídeos sob demanda à medida que esta tecnologia ficar totalmente disponível. Materiais já existentes podem ser oferecidos na TVDi. Nesse modelo observa-se a necessidade de haver receptores com capacidade de armazenamento e não é necessário um canal de retorno como premissa.

- TV personalizada - a TV personalizada é um conceito que poderá ser posto em prática no futuro. Envolve a customização da programação de acordo com o perfil do usuário. Ainda poderia dar ao usuário a possibilidade de assistir seus programas preferidos no momento desejado sob demanda. Como identifica o usuário, poderia ser utilizada para garantir que o usuário realmente assistiu ao programa e para recomendar materiais adicionais, seja um programa ou seja um conteúdo escrito adicional que seja pertinente ao conteúdo estudado.

\subsection{Produção de Conteúdo para t-learning}

No trabalho apresentado por Sharda e Hanumanula (2003) é apresentado um estudo sobre questões de sincronização das mídias educativas para aplicações de autoria de conteúdo. Em uma aplicação para TVDi deve-se considerar a questão temporal, pois as mídias precisam estar sincronizadas e, após o envio dos dados pela emissora para a casa do usuário, por meio do carrossel de dados, esse conteúdo tem que ser apresentado igualmente em todas as TVs que estiverem utilizando a aplicação.

Em Frantzi et al. (2004) os autores propõem uma metodologia que visa integrar o padrão SCORM voltado para conteúdo Web com TV Anytime para alcançar interoperabilidade em TVD e aplicações de aprendizagem eletrônico, assim como associar metadados educacionais com programas de TVD. A metodologia permite também a interoperabilidade entre aplicações educativas em ambientes de TVD e facilita a criação de metadados educativos voltados para programas de TVD. É possível visualizar por meio de um diagrama de objetos o relacionamento que descreve uma aplicação desenvolvida relativa ao mapeamento entre dois padrões: SCORM e TV-Anytime, que permite a transformação dos metadados da TV-Anytime para a criação de objetos de aprendizagem compatível com SCORM para cursos que utilizem material educacional de pro- 
gramas televisivos. A partir de um exame da compatibilidade desses padrões, os autores propõem um sistema capaz de prover critérios semânticos que favoreçam a interoperabilidade de conteúdos alocados, permitindo seu uso como bibliotecas digitais audiovisuais provedoras de serviços educacionais interativos. Em Rodolpho (2009) é apresentado uma arquitetura de software que visa converter, de forma automática, objetos de aprendizagem que seguem o padrão SCORM para a TVD aberta, estando de acordo com os padrões do middleware brasileiro GINGA.

Já Alves et al. (2006) estudam, em particular, os metadados voltados a conteúdos de TVD, observando que nenhum dos padrões de metadados apresentados no estudo é completo para uma solução para TVD, ainda que se complementem em muitos aspectos. Dessa padronização dependem, por exemplo, as possibilidades de reutilização de conteúdos educativos provenientes da Internet em sistemas de TVD. Nesse caso, a maior parte dos conteúdos intercambiáveis concebidos como objetos de aprendizagem utiliza o padrão SCORM.

Nores et al. (2004) comentam a respeito do uso da TVDi para oferecer serviços de apoio a aprendizagem, e em outro trabalho Nores et al. (2006) apresentam uma aplicação que provê serviços educacionais a partir de conteúdos que estão de acordo com o padrão SCORM. No trabalho de Im et al. (2006) é apresentado um sistema para conversão transparente de objetos de aprendizagem em aplicativos para TVDi, porém os conteúdos são convertidos de modo que não se consideram as divergências em usabilidade entre Web e TVD.

Limitações similares podem ser observadas no sistema de Fuks et al. (2007), que provê acesso via TVD aos conteúdos provenientes de um ambiente de aprendizado. Uma forma de combater tais divergências é apresentada por Lopez et al. (2007), com uma solução que engloba também o processo de autoria dos conteúdos educacionais, implicando maior controle na formatação dos conteúdos.

Uma característica marcante nos trabalhos relatados é o enfoque dado ao middleware MHP, conforme é descrito em Morris e Smith-Chaigneau (2005), utilizado no sistema europeu de TVD, tornando-as não-imediatamente portáveis para o ISDTV. Por outro lado, as abordagens de Celes e Souza (2007) e Monteiro et al. (2008), também preocupadas com a apresentação de objetos de aprendizagem, são construídas sobre a linguagem NCL, normativa do sistema declarativo do Ginga (Ginga-NCL).

No Brasil, a convergência entre aplicações de Internet e TVD tem sido buscada como base plataformas próprias de $\mathrm{EaD}$, como é o caso de uma arquitetura de integração por camadas proposta para combinar o middleware GINGA ao sistema de aprendizagem eletrônica Aulanet, usado pela PUC-Rio, na forma de um sistema compartilhado de recursos interativos Fuks et al. (2007). O tra- 
balho de Barrére e Leite (2009) relata esforços para a conversão de conteúdos de EaD, provenientes do LMS Moodle, para a TVDi e está em conformidade com as normas estipuladas pelo GINGA.

\section{6 t-learning e a usabilidade}

Com o foco para além de aplicações educacionais, diversas pesquisas têm se preocupado com a orientação de design para TVDi (Rice e Alm, 2008; Tsekleves et al., 2009; Buchinger et al., 2009; Collazos et al., 2009).

Em particular, a pesquisa realizada por Chorianopoulos e Lekakos (2007) destaca os princípios de design recorrentes na literatura, com o foco no entretenimento, suporte para observação do comportamento social que usa a TV de modo relaxado e navega entre as opções disponíveis por meio do uso do controle remoto. Kunert (2009) desenvolve um extenso catálogo de padrões de design da interface do usuário para a TVDi (por exemplo, padrões para layout de página, o uso de botões do controle remoto, entrada de texto e navegação), todos eles concebidos e avaliados por meio de processos de design centrado no usuário. Problemas semelhantes têm sido salientado por Collazos et al. (2009), que se desenvolvem alguns princípios (por exemplo, a simplicidade, pertinência para o conteúdo principal, o poder de customização, etc) e as orientações para realizar inspeções de usabilidade nas aplicações de TVDi. O design centrado no usuário em aplicações para TVDi foi abordado por Rice e Alm (2008), mas com o foco de investigação voltado para as questões de acessibilidade de idosos.

Recentemente, diversas pesquisas têm procurado compreender e moldar estilos de interação para TVD que sejam aceitos pelos usuários, principalmente aqueles com pouca ou nenhuma familiaridade com essa tecnologia, (Piccolo et al., 2007).

Levando em consideração as expectativas do usuário, Eronen (2004) e Lamont (2003) adotam o paradigma de Design Centrado no Usuário para concepção de produtos para TVD, fazendo uso também de técnicas de pesquisa qualitativa.

Entretanto, pesquisadores como French e Springett (2003) acreditam que o uso de metáforas e de análise semiótica sejam a melhor forma de mapear requisitos para projetos de interfaces aceitáveis, pelo fato de tratar-se de uma tecnologia nova para a grande maioria dos usuários finais. Dessa forma, busca-se a compreensão de meios já consolidados, como o celular e a TV analógica, estratégias para adaptar estilos de interação para a TVD.

Por outro lado, Chorianopoulos e Lekakos (2007) criticam a ênfase que é dada aos aspectos técnicos e computacionais pelas pesquisas da área de 
interação humano-computador, que acabam deixando de lado aspectos relacionados ao conteúdo televisivo. Eles apresentam um modelo conceitual que realmente coloca o usuário de TVD como um telespectador e aborda os conflitos de interesse existente entre emissoras, consumidores, desenvolvedores de aplicações e produtores de conteúdo.

\subsection{Casos de Uso do t-learning}

Alguns exemplos de uso de TVDi na educação, baseado em Andreata (2006), são descritos a seguir.

- SOS Teacher (SOS Professor). A BBCi e a KIT - Kingston Interactive Television apresentaram um software experimental com o foco em t-learning. Os estudantes têm a opção ao acessar serviços disponíveis pela KIT de fazer uma pergunta a um professor real enviando um e-mail utilizando o set-top-box. Os professores respondem a questionamentos via TVDi. As perguntas também são armazenadas de forma que os estudantes possam acessá-las pelo serviço de vídeo sob demanda no horário que desejarem.

- Portal para Aplicações Colaborativas. O projeto InteraTV (Andreata, 2006), desenvolvido, apresenta um portal para TVD que emprega aplicações colaborativas na área educacional, propondo seu uso em um cenário de ensino a distância. Esse portal utiliza o ambiente de desenvolvimento do padrão do middleware europeu, o MHP, baseado na linguagem Java, e contribui com a ideia de agrupar em único portal educacional várias aplicações interativas, exibidas em paralelo ao conteúdo principal televisivo. Porém, por necessitar de um canal de retorno, reduz o público atingido apenas àqueles que possuem acesso à Internet e equipamento específico. Além disso, em algumas situações, como em um chat, requer que o usuário insira símbolos alfa-numéricos; tarefa não trivial quando se utiliza apenas um controle remoto, principalmente para usuários não familiarizados com este estilo de interação.

- Educação para Crianças. O canal CBeebies, ${ }^{3}$ da emissora BBC do Reino Unido, disponibiliza um serviço com a finalidade de desenvolver habilidades em crianças com idade entre 3 e 5 anos. Enquanto a programação televisiva é apresentada na TV, no caso um programa infantil, a criança pode acessar uma série de atividades interativas como, por exemplo, reconhecimento de cores e de caracteres. Esta aplicação ilustra a clara delimitação do público alvo, no caso crianças, o que obriga um rigoroso estudo dos estilos de interação e qualidade da usabilidade, para torná-la

\footnotetext{
${ }^{3}$ http://www.bbc.co.uk/cbeebies/
} 
intuitiva e atraente para seu público. Uma experiência inovadora de uso colaborativo da TVD entre comunidades infantis de aprendizagem foi relatada por Aarreniemi-Jokipelto e Paivi (2007). No trabalho, explorou-se o uso de mensagens instantâneas, com o intuito de adaptar-se para o ambiente televisivo uma forma de interação comunicacional comumente utilizada pelo público educacional visando em suas práticas mais rotineiras na Internet. O objetivo foi testar o uso da plataforma de televisão como suporte ao trânsito de comunicações comunitárias recíprocas a semelhança do que ocorre em listas de discussão, grupos de notícias e salas de bate-papo, com vista a identificar atributos específicos desse fluxo de mensagens em ambientes televisivos.

- Reforço Escolar. O Sistema de Televisão Interativa KIT (Kingston Interactive Television), em parceria com a emissora $\mathrm{BBC}(\mathrm{BBC})$, disponibiliza um canal interativo dedicado ao reforço escolar. O estudante que acessar este serviço pode enviar, por meio do set-top-box, mensagens com dúvidas para uma equipe de professores, que são resolvidas durante a programação televisiva. Essa aplicação exclui os estudantes que não possuem acesso à Internet de participarem do envio de dúvidas.

- Portal de Conteúdo Educativo. Waisman (2006) propõe o desenvolvimento de um portal educacional que reúne alguns tipos de objetos de aprendizagem. O ponto forte desse protótipo é o fato de que ele foi concebido baseado em um estudo sobre usabilidade para aplicações educativas, no contexto da TVD. Entretanto, limita os tipos de objetos de aprendizagem que podem ser utilizados, não redimensiona o conteúdo televisivo principal - fazendo com que o conteúdo interativo o sobreponha quase que totalmente - e não aborda aspectos técnicos relacionados ao ambiente de desenvolvimento.

- Protótipos de serviços usando o padrão ISBDTV. Em Filho e Lopes (2009) os autores relatam o desenvolvimento de uma aplicação desenvolvida para TVD, que visa auxiliar o processo de avaliação de alunos. O sistema tem como objetivo permitir uma interatividade entre alunos e professores, onde a validação do aluno no sistema ocorrerá por meio do seu login e senha de acesso. O software desenvolvido permite a criação de questionários para serem aplicados na TVD. O aplicativo faz uso do canal de interatividade para realizar a comunicação da aplicação com um servidor remoto, fornecendo recursos de interatividade para que o aluno seja avaliado utilizando os recursos do ISBTVD. Em Mourão (2010) é apresentado uma proposta de aplicação para alunos do estado do Amazonas utilizando a tecnologia de TVDi e de celular. Foram levadas em consideração 
as características do middleware brasileiro de TVD, sendo desenvolvida a aplicação em Java segundo as especificações do GINGA-J. Essa proposta utilizou o LMS Tidia-Ae para a criação de um banco de exercícios, para posteriormente exportar um arquivo XML e usa-lo na aplicação pela TV. A aplicação apresenta aos alunos, de todo o estado, as questões que poderiam ser respondidas pelo celular e enviadas pela TV, sendo que essas respostas serão automaticamente repassadas para os professores que estão na capital. Em Monteiro (2009) e Lobato et al. (2007) é apresentada uma aplicação para TVDi, considerando os padrões do middleware brasileiro, GINGA, a partir da geração de conteúdo automática proveniente do LMS Amadeus. Essa aplicação apresenta ao usuário uma interface interativa com os conteúdos a serem estudados no curso em que o aluno estiver inscrito.

\subsection{Considerações Finais}

Os trabalhos apresentados permitem observar que a TV apresenta um grande potencial para a educação a distância, sendo usada há muitos anos com grande eficiência. A evolução da TV analógica para a digital também mantém esse potencial e pode agregar ainda mais serviços úteis à difusão do conhecimento.

Na TVD, surgiu um novo conceito que é o t-learning, muitos o veem como uma extensão do e-learning, mas muita coisa muda de um ambiente para o outro, por exemplo, a postura do usuário, o uso que passa a ser coletivo, etc, indo muito além de padrões diferentes de conteúdo. A fim de tentar reutilizar os conteúdos gerados na Web, foram criados alguns padrões de objetos de aprendizagem. Essa reutilização pode ser também aproveitada para a TVDi, conforme é apresentado na seção Produção de Conteúdo para t-learning. Já na seção seguinte, Integração entre TV e padrões LMS, são descritos os esforços para integrar os conteúdos gerados para a TV e as interações dos usuários para plataformas LMS, fechando assim o ciclo de produção de conteúdo tanto para Web quanto para a TVD.

Na seção "t-learning e a usabilidade"viu-se que os autores estudados relatam que somente converter e gerar conteúdo seguindo os padrões do middleware de TVDi, não é suficiente. Faz-se necessário observar para a usabilidade do sistema, garantindo que o usuário saberá aproveitar, da melhor forma, as funcionalidades disponibilizadas nas aplicações educativas na TV.

Na seção "Casos de Uso do t-learning", a intenção foi apresentar casos de aplicações educativas interativas que foram desenvolvidas em outros países e também estudos desenvolvidos aqui no Brasil para oferecer educação utili- 
zando a tecnologia de TVDi. 


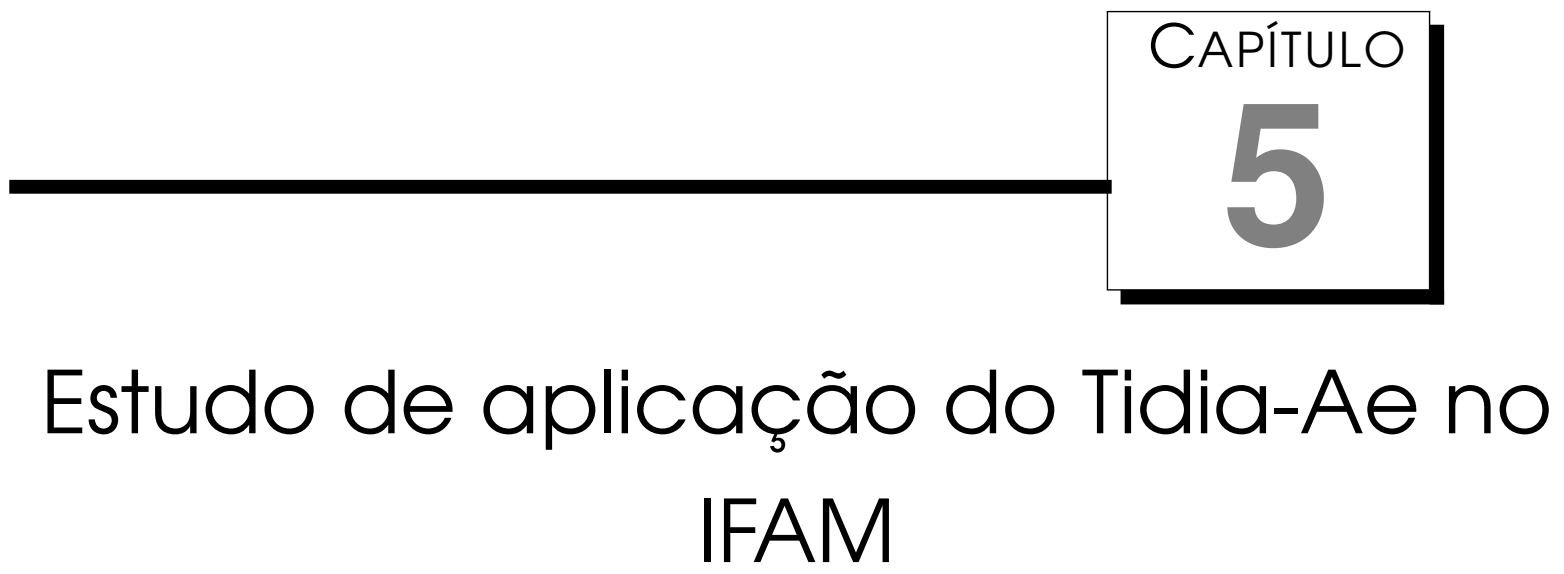

Este projeto estudou uso do LMS Tidia-Ae e suas extensões no cenário de educação a distância, em curso técnico de Meio Ambiente oferecido pelo Instituto Federal do Amazonas (IFAM).

Neste Capítulo serão apresentados, inicialmente, os softwares utilizados nessa pesquisa, descrevendo suas funcionalidades e potencialidades que poderão ser exploradas nos cursos à distância. A seguir, é apresentado o cenário de uso: como o software será estruturado no caso geral desse estudo.

\section{1 Tidia-Ae}

O Tidia-Ae (Tecnologia da Informação no Desenvolvimento da Internet Avançada - Aprendizado Eletrônico) é um LMS desenvolvido pelos pesquisadores das Universidades do estado de São Paulo. É um ambiente que possui ferramentas de suporte ao ensino presencial e a distância.

O projeto Tidia-Ae teve início em 2004, foi concluído em 2009 e teve duas fases. Ademais, foi financiado pela FAPESP (Fundação de Amparo a Pesquisa do Estado de São Paulo) com o objetivo principal de desenvolver um sistema de e-learning explorando o potencial da Internet avançada(largura de banda da ordem de dezenas de gigabits/s) e oferecendo suporte a diferentes necessidades no contexto educacional. O projeto integra diversos grupos de pesquisa e é norteado, principalmente, pelos seguintes objetivos: (i) a criação de um sistema flexível que pode ser montado a partir de um conjunto de ferramentas e funcionalidades selecionadas de modo a satisfazer os vários cenários de 
aprendizagem, bem como para se adaptá-las necessidades dos diversos grupos de pesquisa, (ii) promover a reutilização de ferramentas e / ou funcionalidades desenvolvidas pelo Tidia-Ae, (iii) promover a interoperabilidade com outros sistemas eletrônicos de aprendizagem, (iv) a definição de um processo de desenvolvimento colaborativo entre os diferentes grupos de pesquisa, conforme é apresentado no relatório técnico (Lince-DC, 2010).

No início da segunda fase, optou-se por integrar o LMS desenvolvido na primeira fase do projeto com o ambiente Sakai. ${ }^{1}$ Essa plataforma é um LMS open-source, baseado na tecnologia Java, e é um ambiente que surgiu a partir de parceria entre universidades americanas. O Sakai é um ambiente acessível disponivel na Web que oferece uma série de ferramentas como fórum, wiki, quadro de notas, repositório de materiais, calendário, e-mail, dentre outras.

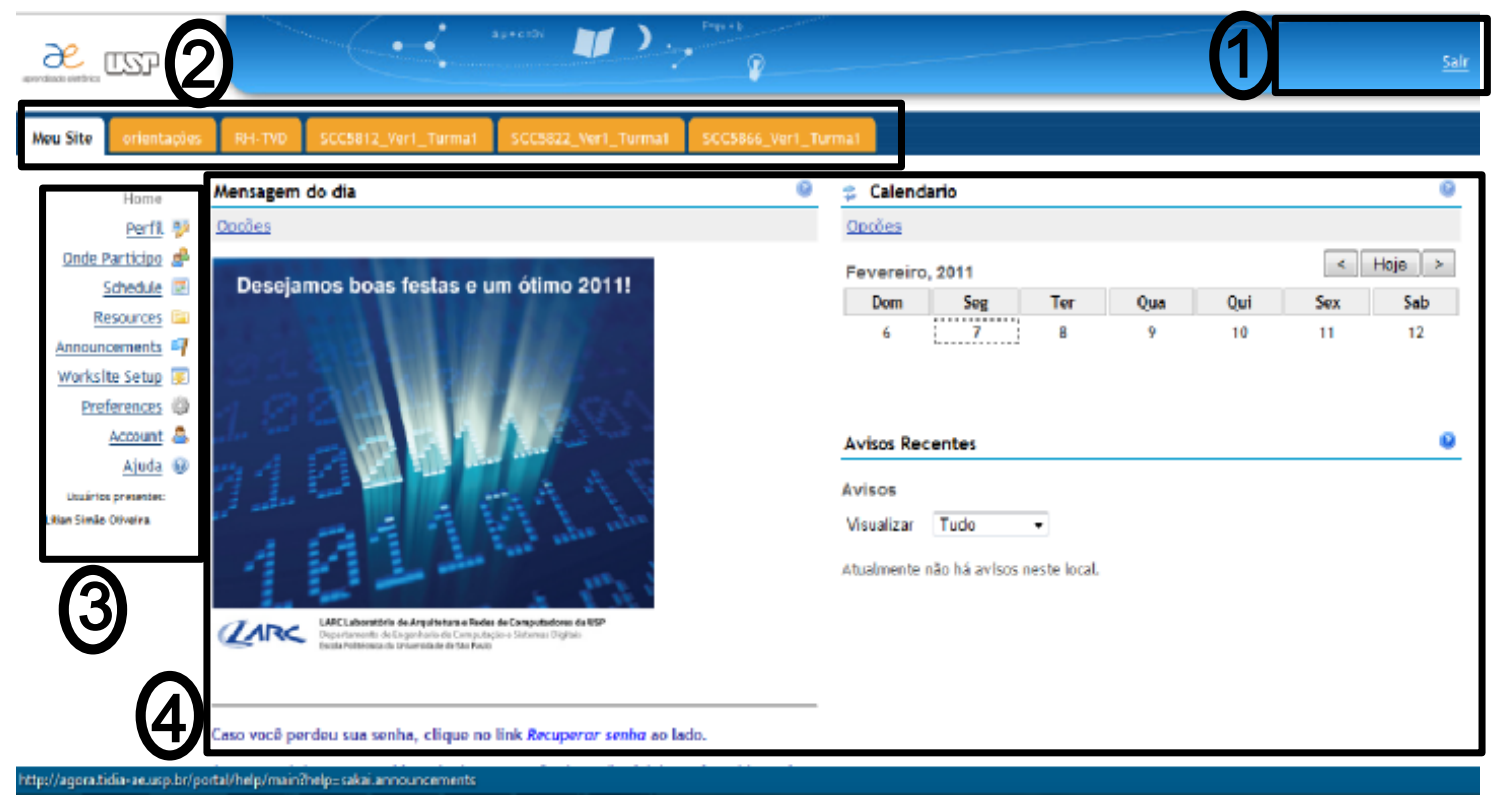

Figura 5.1: Interface do Tidia-Ae, disponibilizado pela USP

A Figura 5.1 mostra a interface principal do Tidia-Ae: 1- área de login e logout, 2- área das disciplinas, essas são apresentadas por meio de abas, 3- área das ferramentas, nessa área são apresentadas as ferramentas disponibilizadas em cada disciplina, 4- área de conteúdo, nesta área que será apresentado o conteúdo pertinente a cada disciplina e ferramenta selecionada.

\subsubsection{DiGaE}

A partir da infraestrutura Tidia-Ae, optamos pelas seguintes ferramentas: o chat baseado em texto, videoconferência e a whiteboard. Essas ferramentas agrupadas e sincronizadas são conhecidas como o módulo DigaE, conforme descrevem Arantes et al. (2010). A Figura 5.2 mostra a relação entre o módulo DiGaE e o Tidia-Ae

\footnotetext{
${ }^{1}$ Maiores informações disponivel no site oficial: http://sakaiproject.org/
} 


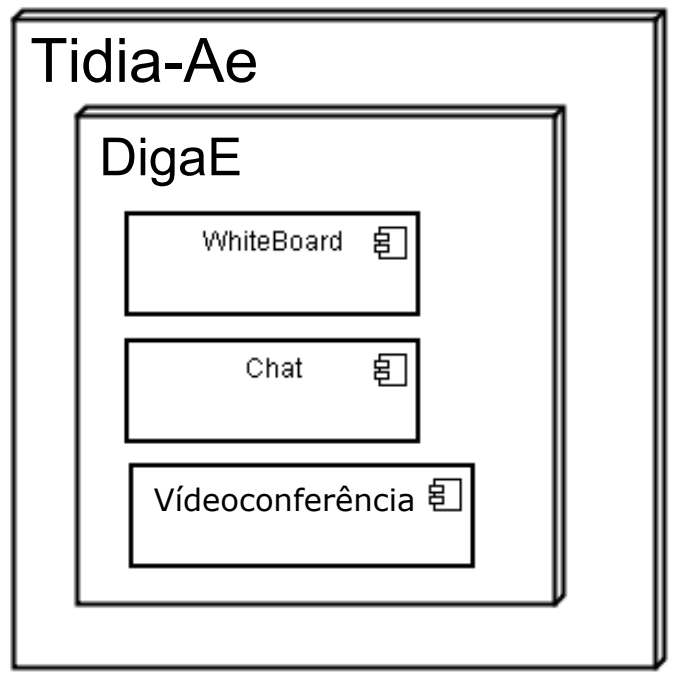

Figura 5.2: Relação de dependência entre o Tidia-Ae e o DiGaE

O Projeto DiGaE (Distributed Gathering Environment) está inserido no contexto do Projeto Tidia e prevê a disponibilização de três ambientes de computação ubíqua para comunicação síncrona de qualidade entre usuários remotos.

A ideia inicial do ambiente DiGaE é que o usuário não tenha sempre que agendar uma sessão para se comunicar com outro (s) usuário (s), mas que a sessão possa acontecer de modo natural, estando os usuários online, eles podem compartilhar seus fluxos de áudio, vídeo, interagir via whiteboard e ainda trocar informações textuais via chat, fazendo uso de uma sala instrumentada.

Essas interações são, então, capturadas e salvas em uma sessão, de modo que possam ser acessadas posteriormente.

Caso não seja usada uma sala instrumentada e configurada para o DiGaE, é necessário agendamento prévio da sessão. Esse cenário pode ser aplicado a uma aula utilizando o DiGaE. No agendamento é informado quem são os alunos que irão participar, quais as ferramentas que serão utilizadas (whiteboard, chat, vídeoconferência), que horas irá iniciar e irá terminar a aula, entre outras informações.

Quando a aula agendada tem início, os alunos e professores poderão entrar na sessão, que estará liberada para uso e apresentará os slides que o professor previamente carregou. No decorrer da aula o professor irá explicar cada slide, podendo escrever na whiteboard, e seu vídeo e áudio serão gravados. Os alunos poderão contribuir na aula por meio do uso da ferramenta chat e também de intervenção nos slides (se for fornecido permissão para isso) ou ainda intervenções por meio do uso da ferramenta de vídeoconferência. Ao final da aula, esse documento multimídia é armazenado, para uso posterior.

Uma vez concluída a aula, o usuário pode finalizar a sessão e editar ou manter os dados referentes a ela (assunto e descrição); os dados de data e duração são gerados automaticamente. O DiGaE identifica e lista os usuários 
participantes e as ferramentas utilizadas. Para o cadastro de uma nova sessão, o usuário especifica seu tema, descrição, data, hora, local, usuários que participarão e também quais ferramentas serão usadas. Há também a opção de consultar sessões agendadas para editá-las ou excluí-las.

Para consultar sessões, o usuário pode optar por colocar o tema associado a ela, a data na qual ela ocorreu, ou ambos. Posteriormente, o usuário pode escolher a sessão de interesse para acessar seus dados (inclusive informações geradas com chat, whiteboard e comunicador instantâneo, no caso de sessões já finalizadas), ou ainda editar os dados da sessão ou excluí-la. No DiGaE a opção de "Ajuda", contendo informações descritivas sobre cada uma das funcionalidades implementadas, auxilia o usuário por meio de textos e imagens sobre como utilizar esse ambiente.

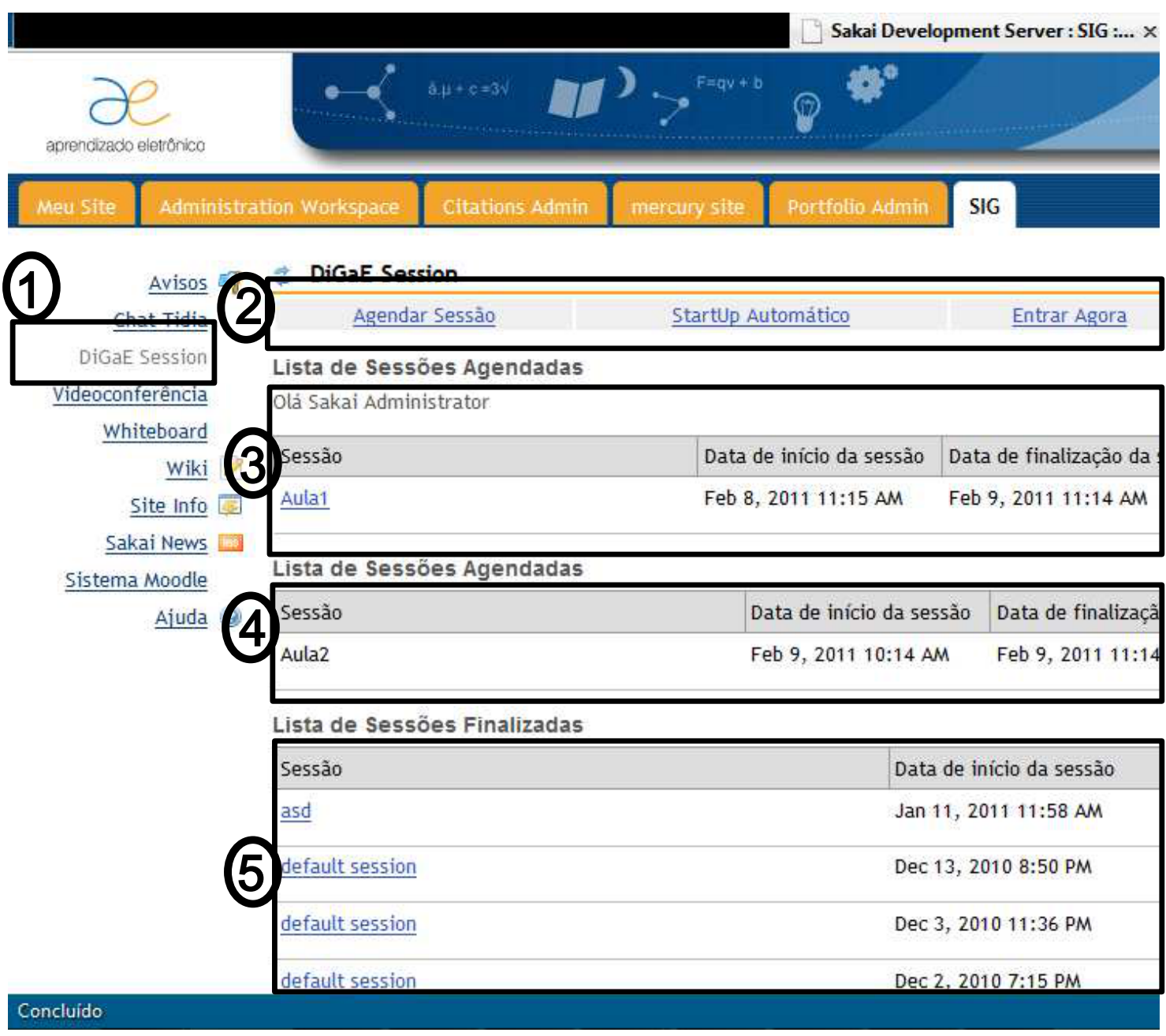

Figura 5.3: Ferramenta DiGaE e suas funcionalidades

A Figura 5.3 apresenta na área 1 a opção da ferramenta DiGaE; na área 2 as funcionalidades disponiveis para usar uma sessão DiGaE, como: agendar uma sessão, marcando hora de início e fim da sessão, usando a sessão default por meio do link "Entrar agora", entre outras opções; na área 3 são listadas as sessões que foram agendadas e estão disponiveis para uso, isto é, o horá- 


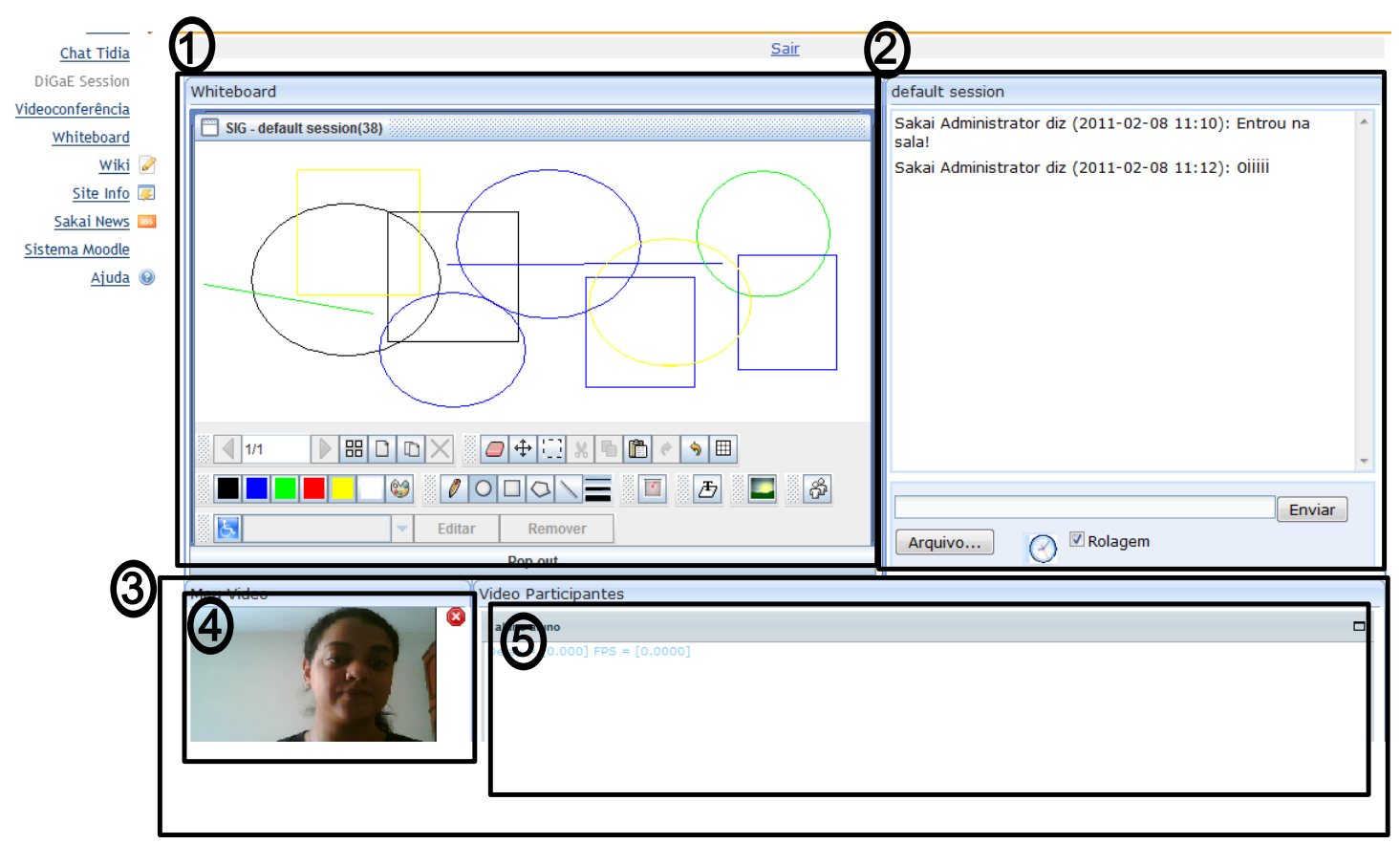

Figura 5.4: Uma sessão DiGaE e suas ferramentas

rio atual está entre os horários inicial e final descritos nas configurações da mesma; na área 4 são listadas as sessões agendadas, cujos horários de início determinados ainda não chegaram, e na área 5 consta a lista de sessões que foram finalizadas.

A Figura 5.4 apresenta uma sessão DiGaE, na área 1 encontra-se a ferramenta whiteboard; na área 2 o chat; na área 3 é a área da vídeoconferência; esta contém a área 4 que apresenta o retorno do vídeo do usuário que está logado e na área 5 aparecem os demais vídeos dos participantes da sessão.

\subsubsection{DiGaE-TV}

O protótipo do DiGaE-TV, segundo Vega-Oliveros et al. (2010), tem como objetivo gerar conteúdo para a TV Digital interativa convertendo automáticamente um documento multimídia, descrito em um arquivo XML, proveniente do LMS Tidia-Ae. O seu uso pode ser aplicado a aulas de educação a distância, tornando possível aos alunos visualizarem conteúdos multimídia de alta qualidade independente da disponibilidade e qualidade da Internet quando transmitido via TV. Essa ferramenta também ajuda o professor na criação de vídeo-aula, pois reduz a complexidade de sua produção, não sendo necessário o uso de um estúdio especializado para a geração da aula.

O fluxo de informações até gerar um documento NCL para ser tocado na TV Digital interativa é apresentado a seguir. Inicialmente uma sessão é criada. Guando chega a hora agendada a sessão é disponibilizada para uso e os participantes inscritos poderão utilizar os recursos disponibilizados para a aula. 
Durante essa aula todas as interações feitas no ambiente DiGaE serão armazenadas. Em seguida essa sessão é encerrada e é gerado um documento XML que contém as descrições de todas as mídias, seus tempos e a relação entre si. Esse documento XML passa por um processamento de conversão e tratamento das mídias para em seguida gerar um documento NCL que contenha interatividade correspondente a aula, com todas as suas mídias sincronizadas.

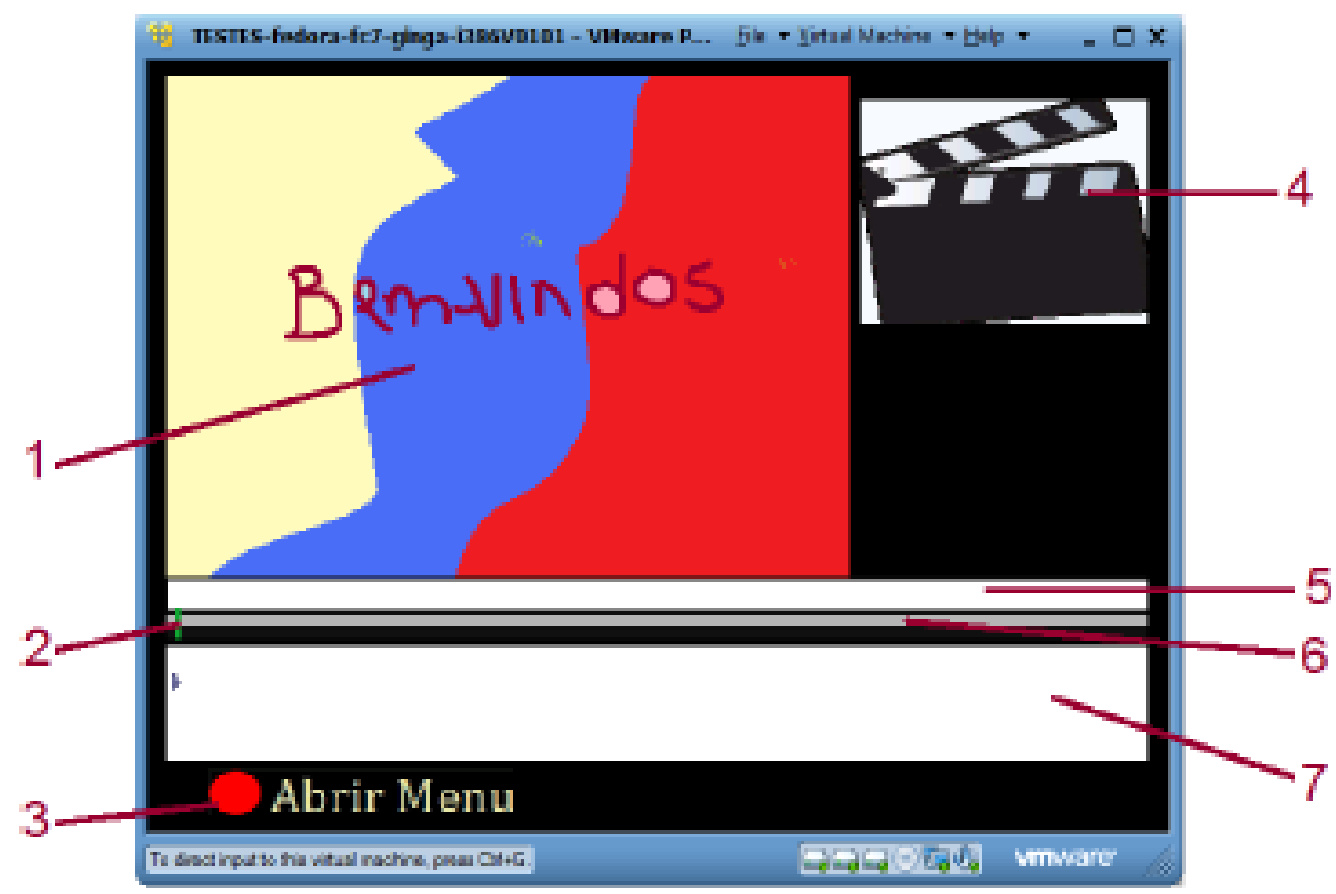

Figura 5.5: DiGaE-TV e as áreas de conteúdo

Na Figura 5.5 é apresentada a interface do DiGaE-TV e as suas funcionalidades, que são:

1. Determina a área da whiteboard que foi usada pelo professor quando fez a captura da aula. Nesta região estão relacionados os slides usados, os traços/desenhos feitos pelo professor e informação relacionada ao conteúdo (títulos-temas) dos slides.

2. É o cursor de interação do usuário sobre a linha de tempo.

3. O menu de opção de interação, que indica a ação a ser tomada no momento ao se acionar o botão vermelho do controle remoto.

4. Região dos vídeos capturados durante a sessão. No caso dessa figura, temos somente o vídeo do professor.

5. Caixa de texto que indica o texto do "Interactor"que está sendo apresentado no momento e da configuração de busca criada pelo usuário. 
6. Ilustra a linha de tempo da aplicação e o seu estado.

7. Região relacionada à sessão de chat que foi capturada durante a sessão.

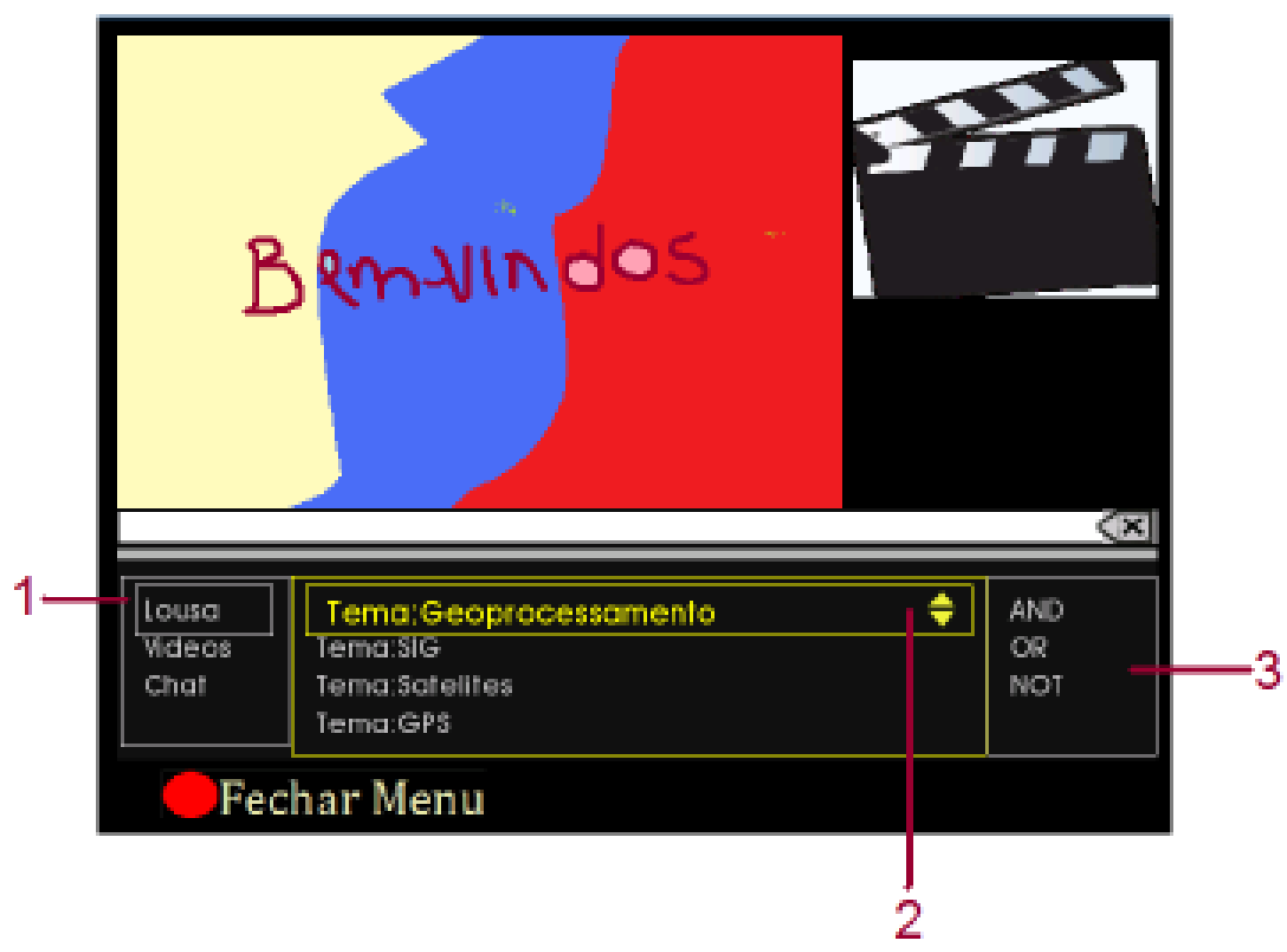

Figura 5.6: Menu do DiGaE-TV

Existe uma serie de ações ou interações que o usuário pode fazer durante uma sessão do DiGaE que de alguma forma poderiam ser recuperadas. Esta informação depende dos diferentes tipos de mídias que foram capturadas na sessão. Por exemplo, no caso da captura de um vídeo, o usuário pode falar e se expressar com os outros participantes: isso faz com que seja possivel determinar, mediante a análise do vídeo, os momentos em que o participante estava falando ou estava calado, ou quando estava se mexendo, ou tinha saído, ou havia levantado o braço para fazer alguma pergunta, etc.

Esses tipos de ações são consideras como eventos de interação de um determinado operador de interação. Para o caso de um áudio capturado, podemos encontrar todos os pontos em que alguém estava falando, determinando desta forma os momentos de fala do usuário X da sessão.

Em relação à interatividade da aplicação, existe um menu que permite acessar pontos específicos do documento, mostrado na Figura 5.6. Esses pontos de interação, também conhecidos como Interactors podem ser referentes às diferentes ferramentas: a whiteboard, ao vídeo e ao chat. Esse termo generaliza o termo inkteractor (Pimentel et al., 2005) que refere-se a interações 
com uso de tinta digital, posteriomente também foi utilizado por Cattelan et al. (2008). Nesse protótipo esse conceito foi expandido para as demais mídias. As opções de Interactors em cada mídia são disponibilizadas no menu. Para entrar no menu o usuário precisa usar o botão vermelho do controle remoto.

Quando se abre o menu da aplicação temos os seguintes elementos:

1. Mostra as ferramentas que foram usadas durante a sessão grava no DiGaE pela Web.

2. Mostra os operadores de interação (Interactors) que pertencem as mídias. Neste caso, são mostrados os operadores relacionados à whiteboard.

3. Mostra a seção de operadores lógicos que podem ser usado para criar busca de pontos de interesse na sessão. O AND funciona como um and lógico; $\mathrm{X}$ and $\mathrm{Y}$ apresentará todos os pontos de $\mathrm{X}$ e $\mathrm{Y}$ que estejam relacionados ao mesmo tempo. O operador $O R$, no caso de $\mathrm{X}$ or $\mathrm{Y}$, apresenta como resultado ambos os pontos. Finalmente, o operador NOT, no caso $\mathrm{X}$ not $\mathrm{Y}$, mostrará todos os pontos contidos em $\mathrm{X}$ cujo intervalo de tempo não esteja relacionado com elementos de $\mathrm{Y}$.

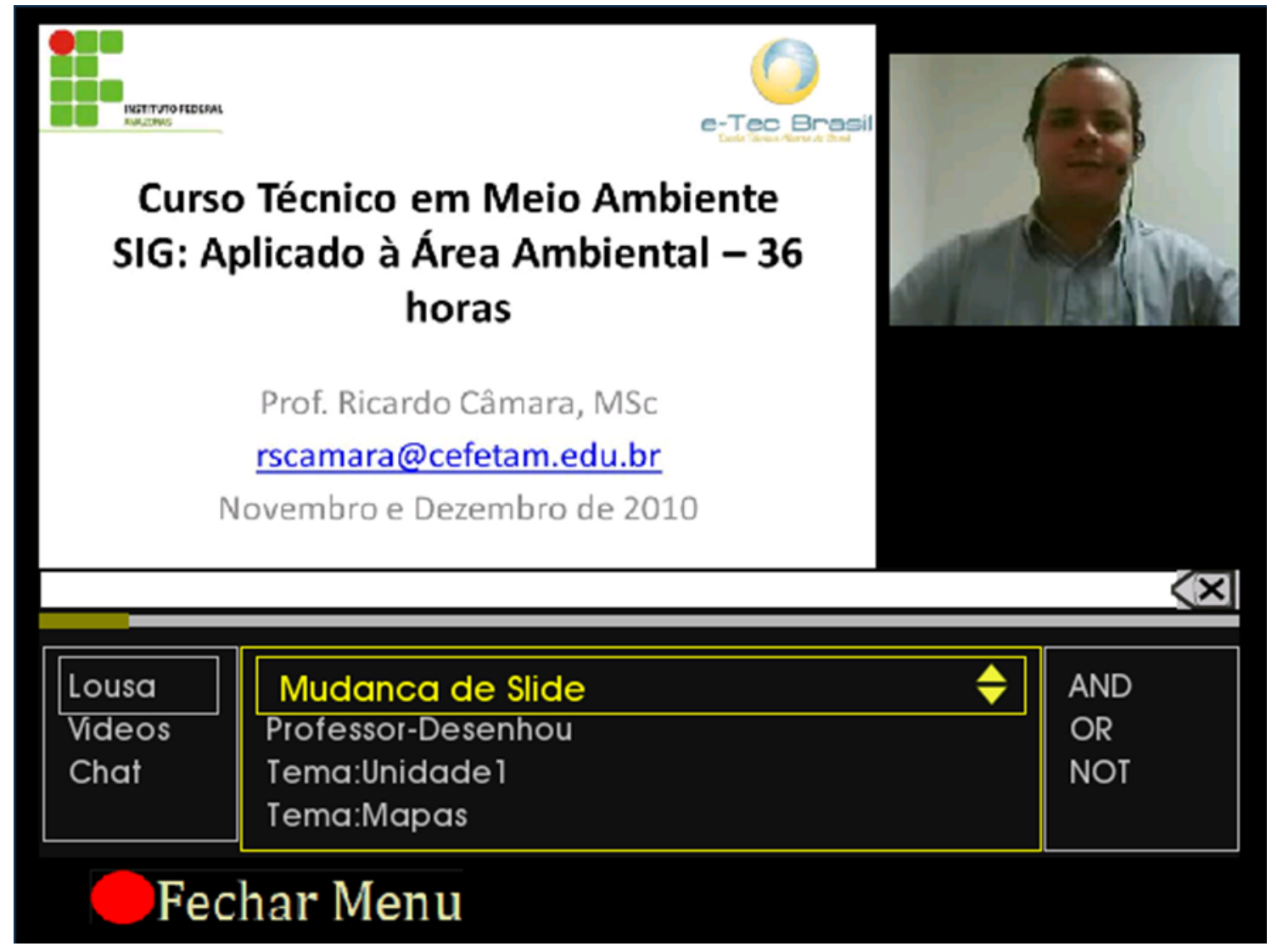

Figura 5.7: Exemplo de uso do DiGaE-TV em uma aula do IFAM

A Figura 5.7 apresenta um exemplo de uso do DiGaE-TV em uma aula ministrada por um professor do IFAM, no curso técnico de meio ambiente. 
Uma característica dessa ferramenta é que as aulas não serão ao vivo, devido o tempo de conversão e envio para a emissora até a transmissão para os alunos.

Com a plataforma Tidia-Ae espera-se que as Instituições de Ensino possam criar materiais educativos sem a necessidade de estudos profissionais, por exemplo, e que o sistema se preocupe com a conversão e adaptação desse conteúdo para ser apresentado na TV. É importante resaltar que a conversão é transparente para seus usuários (professores e alunos) e que possibilita diversas maneiras de assistir uma aula.

Esse cenário é ilustrado na Figura 5.8 e detalhado na seção seguinte.

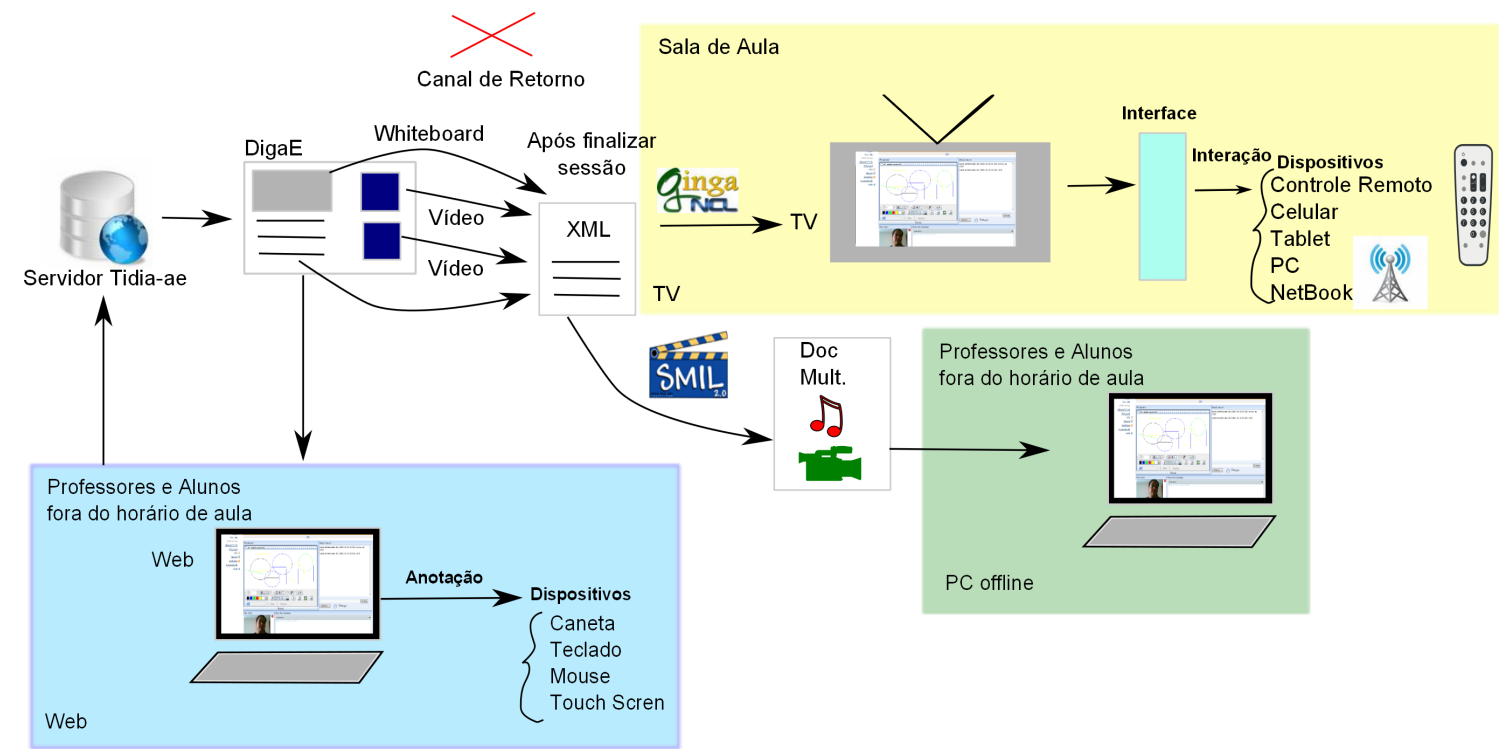

Figura 5.8: Cenário de uso da ferramenta DiGaE na EaD

\subsection{Cenário do Estudo de Caso}

O cenário deste projeto é ilustrado pela Figura 5.8. Nele utiliza-se a ferramenta DiGaE, que pode conter as ferramentas de chat, whiteboard e vídeoconferência. Na figura foram utilizadas as três ferramentas. Um aluno poderá utilizar essas ferramentas pela Web para fazer autoria de um documento multimídia, podendo anotar nos slides utilizando diversos dispositivos como: teclado, mouse, caneta ou touch screen. São gravados, também, todas as mensagens de textos escritas e o vídeo dos participantes da sessão. Essas marcações são salvas e poderão ser gerados novos documentos multimídia a partir dessas informações, por exemplo, um documento com o resumo de todas as marcações e os conteúdos que os alunos tiveram mais dúvidas. Esse documento multimídia é descrito em um documento XML, o que facilita o seu uso em diversas plataformas como TV, Web e celular. 
Uma sessão poderá ser uma aula, que pode ser agendada ou, também, pode utilizar a sessão default disponibilizada pela ferramenta. Quando a sessão estar aberta, isto é, o horário atual está entre o horário inicial e final definido, é possível os professores e alunos acessarem e interagirem durante a aula. Depois de finalizada uma sessão, a aula não poderá mais salvar nenhum conteúdo, não é possível editar informações referentes a sessão. Após finalizada uma sessão, esse conteúdo multimídia salvo é convertido automaticamente para a linguagem SMIL (Synchronized Multimedia Integration Language). ${ }^{2}$ Como ilustrado na Figura 5.9.

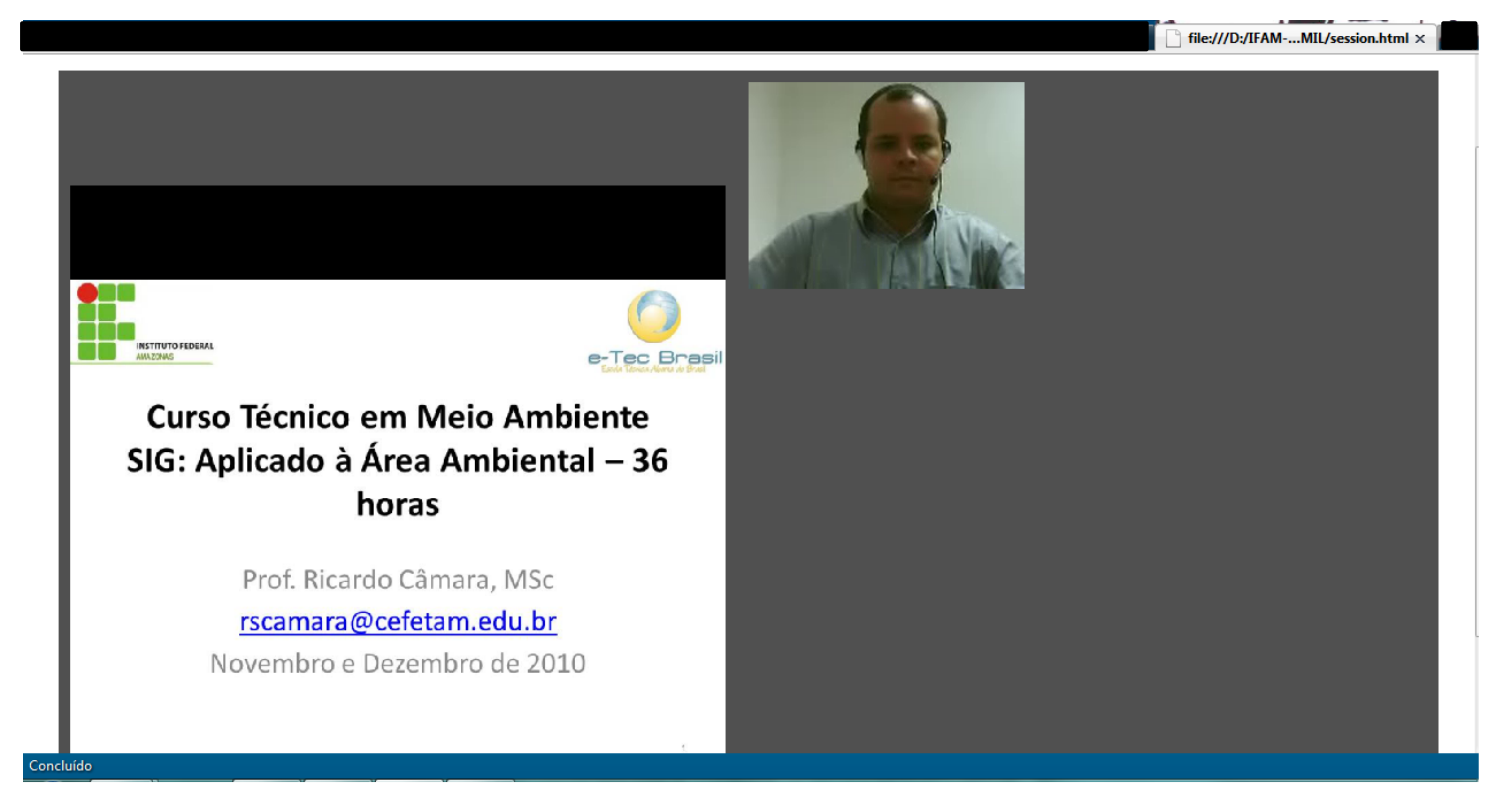

Figura 5.9: Visualização de uma aula no formato SMIL no browser

SMIL é uma linguagem semelhante com o padrão HTML, no sentido de possuir tags para descrever o conteúdo multimídia. É uma linguagem de integração que sincroniza os elementos multimídia (vídeo, áudio, texto) e apresenta como um único documento multimídia interativo.

Uma aula gerada no formato SMIL, a partir de uma sessão DiGaE, poderá ser assistida usando o próprio browser do usuário, conforme Figura 5.9, ou ainda por meio de um player, por exemplo o RealPlayer, ${ }^{3}$ conforme Figura 5.10. Também pode ser feito o download do arquivo multimídia, para ser assistido posteriormente off-line em qualquer player compativel. Quando é feito o download da sessão, é salvo um pacote que contém um conjunto de arquivos referente as mídias, entre eles estão, o documento XML que descreve cada mídia gerada a partir da sessão gravada indicando qual é o arquivo da mídia, seus tempos de inicialização e sua relação com as demais mídias. Esse

\footnotetext{
${ }^{2}$ Maiores informações a respeito no site: http://www.w3.org/AudioVideo/

${ }^{3}$ Site oficial: http://brasil.real.com/playerplus/
} 


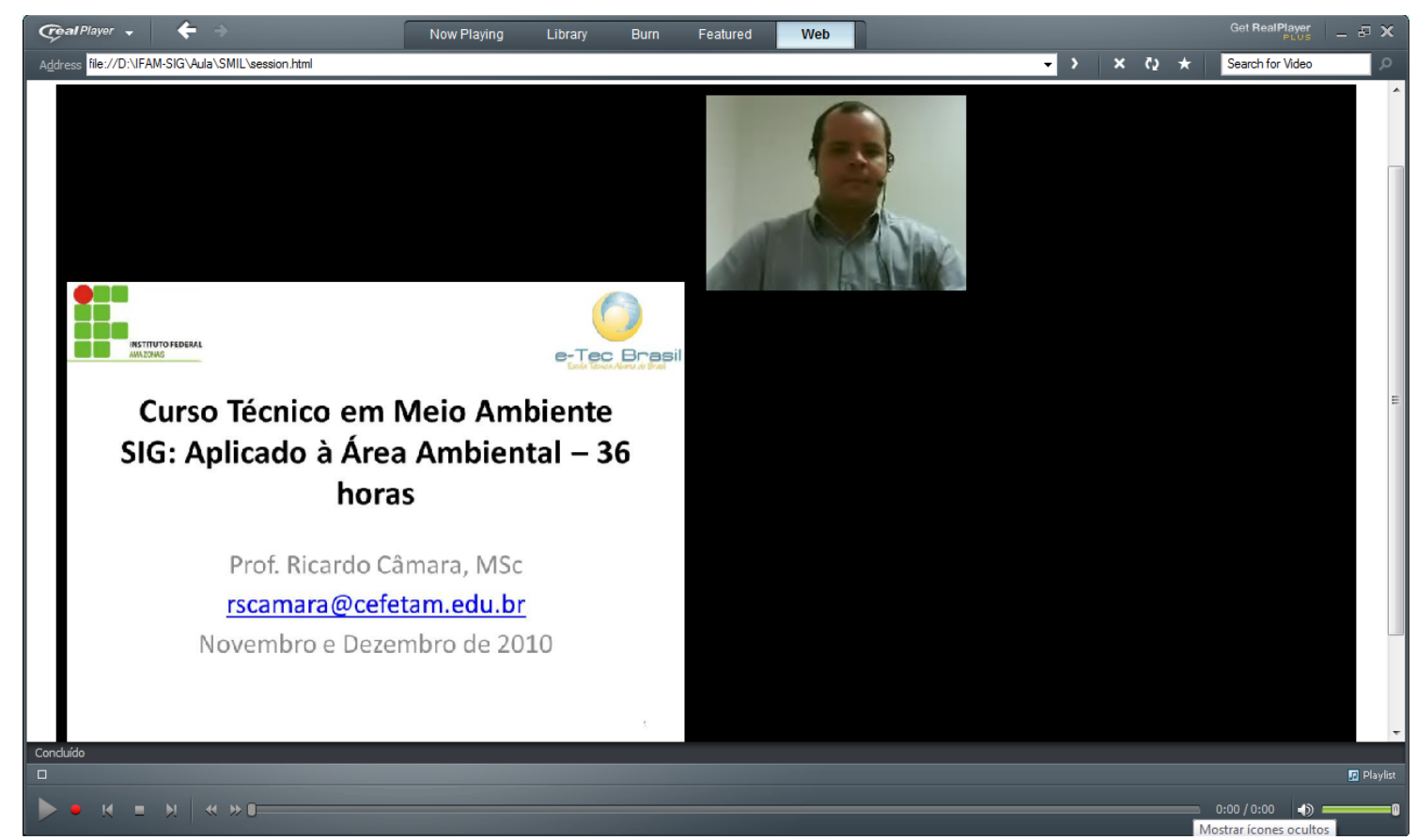

Figura 5.10: Visualização de uma aula no formato SMIL no RealPlayer

arquivo XML, posteriormente, passa por um processo de conversão que gera documentos no formato NCL e Lua. É importante resaltar que esses documentos multimídias podem ser utilizados para a apresentação da aula na TVDi, pois estão de acordo com a norma do middleware GINGA. O estudo de caso apresenta o uso da ferramenta de autoria de conteúdo multimídia, DiGaE, descrita a cima no curso de Meio Ambiente oferecido pelo IFAM.

Hoje, cada disciplina oferecida pelo IFAM utiliza o Moodle como ferramenta de apoio ao ensino, servindo também como meio de comunicação entre alunos, tutores e equipe técnica. Para cada disciplina esse LMS irá apresentar as ferramentas de fórum e atividades. A ferramenta de chat, apesar de ser desejada pelos professores, não pode ser utilizada devido a baixa velocidade da conexão da Internet disponibilizada nos polos em que os cursos são oferecidos. Os alunos recebem uma apostila impressa e, em algumas disciplinas, um CD com conteúdo adicional referente as aulas que serão estudadas. Algumas vezes essa apostila é disponibilizada pelo ambiente Moodle, sendo a responsabilidade de impressão e distribuição dos tutores presenciais. Essas apostilas disponibilizadas pelo ambiente não podem ter um tamanho grande, para poder garantir o seu recebimento em todos os polos. Devido a isso, é recomendado aos professores que não utilizem figuras, tornando as apostilas somente textuais. A mesma recomendação é feita para os demais conteúdos oferecidos na Web. Os alunos estudam pelos materiais preparados pelo IFAM e por livros disponibilizados na biblioteca local. Em cada disciplina o professor visita o polo apenas uma vez, para conversar com os alunos, esclarecer dúvidas e, se for o caso da disciplina, desenvolver alguma atividade prática. 
Este estudo propõe o uso da ferramenta DiGaE para autoria de conteúdos multimídias pelos professores. Conteúdo esse que poderá ser assistido pelo aluno no computador que encontra-se no polo ou em sua casa. Também poderá ser transmitido pela TV em um horário específico, que exigiria do aluno estar presente no polo, porém garantiria que ele assistisse com qualidade de imagem e som a aula multimídia preparada. Os alunos poderiam enviar uma dúvida para o professor utilizando a mesma ferramenta de autoria. Essa ferramenta poderia ser viável para os alunos que tem dificuldade de descrever textualmente o problema em relação a determinado assunto. Ele poderia usar os recursos da whiteboard para descrever em qual slide ele não entendeu e, ainda, utilizar o áudio para expressar-se mais naturalmente. Essa dúvida seria armazenada no ambiente Tidia-Ae e, posteriormente, seria visualizada pelo professor que poderia responder individualmente para o aluno utilizando a mesma ferramenta ou explicando para todos na aula seguinte. Esses recursos serão estudados com o objetivo principal de prover alternativas de ferramentas de apoio a educação em regiões com restrições na qualidade da Internet.

Para avaliar a viabilidade de uso dessa ferramenta nesse cenário foram feitos alguns testes com os alunos de Eirunepé, cidade do interior do estado do Amazonas que possui um polo do IFAM e oferece o curso de Meio Ambiente. Um professor do IFAM, que se prontificou em participar dos experimentos gravou uma aula sua utilizando a ferramenta DiGaE. Essa aula foi salva, posteriormente, gerado um documento multimídia SMIL e, por fim, convertido para o padrão NCL, conforme descrito na seção DiGaE-TV. As experiências obtidas, a partir de testes e observações, foram:

1. experiência dos alunos de Eirunepé, que retrata a avaliação da ferramenta DiGaE-TV e da ferramenta DiGaE. Foi realizado um teste em que era solicitado aos alunos assistir a vídeo aula gravada utilizando ambas ferramentas e, posteriormente, verificar qual foi a diferença de aprendizagem entre os alunos que tinham ferramentas de acesso e interação com o conteúdo, dos que tinham somente uma aula multimídia sendo apresentado;

2. teste de usabilidade: ferramenta DiGaE, esse teste foi realizado com alunos de Eirunepé e com alunos do IFAM de Manaus que cursam o programa de Educação para Jovens e Adultos(EJA) com a finalidade de avaliar a usabilidade do sistema DiGaE na tarefa de gravação de dúvida utilizando a ferramenta DiGaE;

3. teste de sincronismo entre servidores Tidia-Ae, foi realizado um teste que simulou o sincronismo entre dois servidores localizados geograficamente 
distantes com a finalidade de possibilitar aos alunos o acesso ao ambiente Tidia-Ae, localmente e atualizando diariamente o servidor principal, sendo possivel então, oferecer uma possibilidade de acesso a conteúdos educativos multimídias;

4. relatos do professor da disciplina de SIG (Sistema de Informação Geográfica) e do coordenador do núcleo de educação a distância do IFAM que foram obtivos a partir de entrevistas não estruturadas;

5. avaliações heurísticas, foram realizadas com especialistas em Design de interface e interação, nas ferramentas DiGaE e DiGaE-TV com a finalidade de obter mais dados referente a usabilidade do sistema e poder possibilitar aos alunos uma ferramenta que atenda às suas necessidades.

\subsection{Considerações Finais}

Como visto nos Capítulos anteriores, os projetos que utilizam ferramentas como a TV são muito bem aceitos e aproximam os alunos, pois a TV está disponivel a maioria da população e disponibilizam conteúdos de qualidade. Porém, uma grande dificuldade destes programas é fornecer possibilidades para o aluno esclarecer uma dúvida, isto é, o retorno das informações para os professores. A conversa é, na maioria das vezes, de uma única via - dos professores para os alunos. Percebe-se também que a TV é a tecnologia que consegue atingir todos os municípios do estado e o mesmo não acontece com a Internet, nem com o celular.

A intenção deste projeto é, então, unir as tecnologias de TV e Internet para aproveitá-las e possibilitar a difusão dos cursos a todos os municípios do estado.

O interesse em utilizar a TV Digital é devido às vantagens oferecidas de transmissão de vídeo de qualidade, conforme apresentado no cenário de estudo. Esse interesse leva em consideração que a Internet na grande maioria das cidades do estado do Amazonas não possui largura de banda suficiente para o uso de vídeos e outros formatos de arquivos que exijam uma conexão de Internet boa e contínua, sendo o recomendável $375 \mathrm{Mbps}$.

No Capítulo a seguir são apresentados os resultados das avaliações realizadas. 


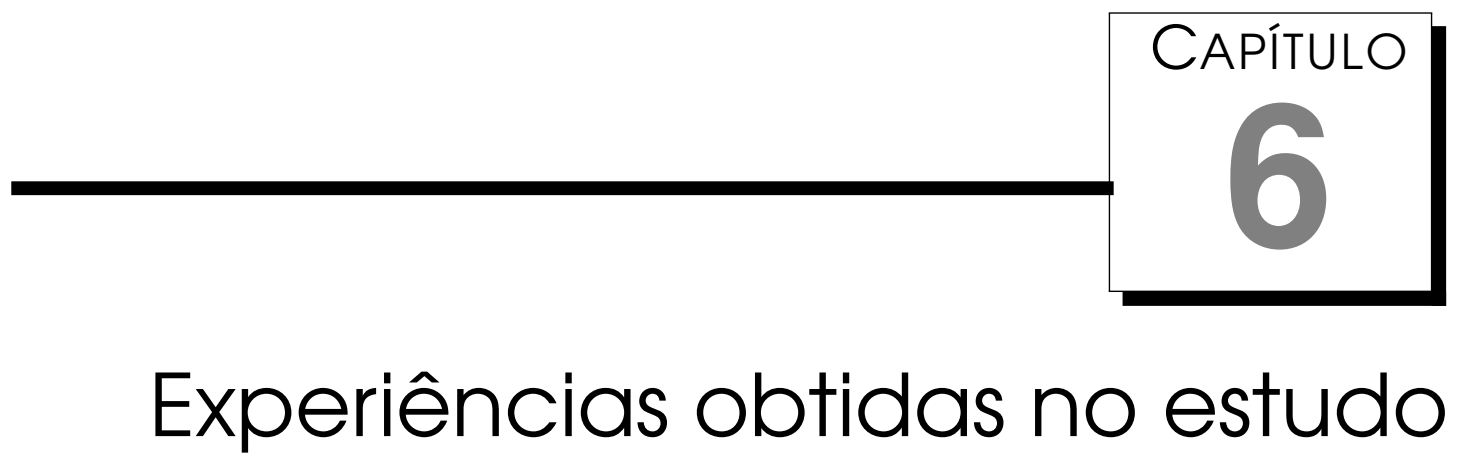

Após selecionar os aplicativos a serem estudados, foram realizadas avaliações com o público alvo e com representantes qualificados, a fim de obter uma observação referente ao uso das ferramentas no dia a dia de um curso oferecido a distância.

O principal objetivo dessas avaliações foi observar algumas das potencialidades que esses softwares apresentam no contexto de ensino a distância, além de compreender melhor dificuldades que os alunos que cursam essa modalidade de ensino enfrentam. Essas informações foram obtidas por meio de relatos dos próprios alunos e observações feitas durante os testes propostos.

Para essa fase deste projeto foi selecionado um estudo de caso o curso de meio ambiente do IFAM. O polo escolhido para aplicação das avaliações foi o da cidade de Eirunepé, que se situa ao leste da capital do Amazonas e dista, aproximadamente, $2.417 \mathrm{~km}$ por via fluvial de Manaus. A cidade possui, segundo o IBGE (2010), aproximadamente 30 mil habitantes. Esse polo foi escolhido devido à grande quantidade de alunos inscritos no curso, inicialmente a turma possuía 50 alunos, atualmente conta com 42 alunos que participa, ativamente das atividades propostas. O polo possui uma das melhores infraestruturas comparadas com os demais polos.

Para os testes de usabilidade, além de contar com um aluno de Eirunepé, participaram do teste alunos do IFAM de Manaus matriculados em cursos técnicos do programa EJA (Ensino de Jovens e Adultos). Esse grupo foi escolhido devido à faixa etária e conhecimento de tecnologias similar aos alunos de cursos a distância oferecidos por essa instituição. Ambos os grupos de alunos já concluíram o ensino médio e voltaram a estudar a fim de complementar os estudos e aumentar as chances de emprego no mercado de trabalho. Os 
conhecimentos de uso de computadores e Internet são restritos e muitos se classificam como tendo conhecimento moderado nessa área. Ambos os grupos tiveram cursos de informática básica, que visa o aprendizado inicial para uso do computador e o nivelamento de conhecimento entre os alunos da turma.

Um professor do IFAM participou dos testes, gravando uma aula de $15 \mathrm{mi}$ nutos que seria apresentada pessoalmente em Eirunepé, para ser apresentada utilizando as ferramentas estudadas. Ele também disponibilizou o uso do horário da sua primeira aula presencial para o estudo. Sua disponibilidade foi de grande valia para os testes e também permitiu observar seu interesse no uso das ferramentas.

\subsection{Experiência dos alunos de Eirunepé}

Uma experiência realizada para avaliar o uso da ferramenta DigaE-TV contou com a participação dos alunos de Eirunepé, que estão inscritos no curso técnico de meio ambiente oferecido pelo IFAM.

O teste consistem em dividir os alunos em dois grupos, um assistiu a aula gravada pelo professor do IFAM da disciplina SIG (Sistema de Informação Geográfica) utilizando o aplicativo DigaE-TV, e o outro grupo assistiu a aula utilizando o documento multimídia SMIL. Esse segundo grupo não teve a possibilidade de interação com o conteúdo, já que o documento gerado é um documento que sincroniza as mídias e possibilita a apresentação como um vídeo, sem nenhuma forma de acesso a um conteúdo específico. O primeiro grupo contou com a participação de 5 alunos e o segundo com 4 alunos.

Após os alunos assistirem a vídeo-aula, foram feitas 5 perguntas relacionadas ao conteúdo apresentado pelo professor. Foram anotadas as respostas dos alunos para análise posterior. Foi observado também o comportamento dos estudantes em relação aos aplicativos apresentados.

\section{Resultados}

O teste foi desenvolvido dividindo os alunos em 2 grupos:

- Grupo A: assistiu à aula fazendo uso da ferramenta DigaE-TV, e ao final os participantes tiveram que responder o questionário. Eles poderiam utilizar os recursos do aplicativo para encontrar a resposta na vídeo-aula.

- Grupo B: assistiu à aula assistindo a documentos SMIL, e ao final do teste respondeu às perguntas referentes ao conteúdo da aula apresentada

Os alunos estão na faixa etária entre 15 - 39 anos, concentrando-se principalmente entre 20-24 anos.A maioria era de mulheres, sendo apenas 22\% 
homens. Quanto à experiência com tecnologia, a maioria possui alguma experiência ou experiência moderada. Todos possuem mais de um ano de uso de computador, podendo chegar até a de 4 anos. Utilizam o computador, principalmente em casa e na escola. Em média, o tempo diário de uso é de 2-5 horas. Todos utilizam o Windows como sistema operacional; alguns poucos (11\%) também utilizam ou já usaram alguma distribuição Linux. As ferramentas de software usadas pelos alunos são: o Moodle, processadores de textos, CD-ROM multimídia. Todos utilizam o Moodle como ambiente de aprendizado eletrônico, no curso a distância de Técnico em Meio Ambiente pelo IFAM. A grande maioria avalia a Internet que possui como ruim e a utiliza diariamente entre 1-3 horas. No ambiente Moodle, todos descreveram que acessam fóruns, atividades disponibilizadas e também o material das aulas. Outros ainda disseram que utilizam chat, vídeoconferencia e mensagens instantâneas para conversar com os professores. A maioria avaliou como fácil o uso do Moodle.

Fatos interessantes constatados no perfil dos usuários:

- Um aluno se considera sem nenhuma experiência com tecnologia, porém informa que já utiliza o computador há mais de 3 anos.

- Quanto às ferramentas utilizadas no Moodle, foi informado pela coordenação do curso que não é disponibilizado o chat, devido a qualidade da Internet que não permite o seu uso da maneira desejada. Mesmo assim, alguns alunos informaram que utilizam chat e vídeoconferência, deve ser utilizando fora do ambiente Moodle.

- Um aluno que declarou como difícil o uso do moodle, estava se referindo a dificuldade de acesso, tempo de carregamento da página da disciplina e não à usabilidade do sistema.

O Grupo A, que usou a ferramenta DigaE-TV, reportou que a ferramenta: é de fácil utilização; a organização das informações está boa; o layout da tela está claro; a nomenclatura utilizada está um pouco confusa; as mensagens do sistema não estão tão claras quanto deveriam e a assimilação das informações é fácil.

O Grupo B, que utilizou documentos SMIL, reportou que a ferramenta: é de fácil utilização; a organização das informações está boa; o layout da tela está claro; a nomenclatura utilizada está clara; as mensagens do sistema estão claras e a assimilação das informações é fácil.

As respostas apresentadas pelos alunos:

- Grupo A - Das 5 perguntas apresentadas, os alunos responderam corretamente $68 \%$ do questionário; 
- Grupo B - Das 5 perguntas apresentadas, os alunos responderam corretamente $65 \%$ do questionário.

Houve um aluno que participou do Grupo A, que após apresentar o sistema DigaE-TV e serem feitas as perguntas, se recusou a usar o sistema com a justificativa de que perderia tempo e daria trabalho procurar a resposta. Alguns alunos, mesmo procurando na aula a resposta correta, viram a resposta e não compreendem o que foi pedido, respondendo, assim, incorretamente. Também foi possivel observar que alguns alunos que participaram do Grupo B (SMIL) prestaram atenção na vídeo-aula e conseguiram aprender bem o conteúdo, respondendo corretamente as questões, mesmo assistindo somente uma vez a aula e não tendo a possibilidade de procurar a resposta correta.

O resultado desse teste apresenta que o aluno precisa estar motivado para participar e aprender, para poder obter diferenças em relação ao nível de aprendizado dos alunos. Comentários obtidos durante os testes foram que aplicações multimídia facilitam o entendimento se compararmos com os materiais que hoje eles tem disponíveis e que são somente textuais, porém, em relação ao nivel de interatividade do aluno, isto é, permitir que o aluno manipule o vídeo da aula, não teve grande influencia em seu grau de aproveitamento do conteúdo lecionado.

\subsection{Teste de Usabilidade: Ferramenta DigaE}

Os usuários preferem sistemas que sejam fáceis de usar, eficientes e seguros. Um teste de usabilidade é necessário para a certificação de que os usuários podem vir a utilizar o produto de modo adequado e eficiente, além de apontar cinco boas razões para se investir em testes com o usuário:

1. Os problemas são consertados antes de o produto ser lançado, não depois;

2. A equipe pode se concentrar em problemas mais concretos, não imaginários;

3. O tempo para que o produto entre no mercado é menor;

4. Após a entrega da primeira versão, o departamento de vendas apresentará um design sólido que poderá ser vendido sem que tenha de se preocupar se ele vai funcionar realmente nas versões seguintes.

\section{Resultados}

Participaram dos testes 7 alunos do IFAM, sendo 1 do curso técnico de meio ambiente a distância lotado no polo de Eirunepé e os outros 6 partici- 
pantes de cursos técnicos do IFAM de Manaus que participam do programa EJA (Educação de Jovens e Adultos).

O teste contou com estudantes que haviam idade entre 15-39 anos, estando concentrados na faixa de 25-29 anos. A maioria dos participantes era do sexo feminino, sendo somente 2 do sexo masculino. Quanto à experiência com tecnologia, eles se classificaram com alguma experiência ou com experiência moderada, somente 1 participante se declarou sem nenhuma experiência.

As respostas informadas indicam que o tempo que eles utilizam computador é menor que 1 ano (29\%) ou maior que quatro anos (29\%). Seu uso acontece principalmente em casa (71\%), seguido na escola (57\%) e por último no trabalho (29\%). O tempo gasto nesse uso por dia é menor que 2 horas ou está entre 2 horas e 5 horas diárias. Todos conhecem o sistema operacional Windows e somente 2 alunos conhecem ou utilizam alguma distribuição do Linux.

As ferramentas mais utilizadas por eles são: planilhas, processadores de texto, programas de apresentação, CD-ROM/Multimídia, ambientes suporte ao ensino/aprendizagem. O uso da Internet por dia é de 1 a 3 horas diárias, em sua maioria e a qualidade da Internet utilizada é considerada regular.

Para cada aluno foi entregue uma lista de tarefas que informava os passos a serem realizados para gravar uma dúvida para o professor utilizando os recursos disponiveis na ferramenta DigaE.

Os principais problemas encontrados foram:

- Fazer download da sessão, pois não havia nenhuma informação que sinalizasse como fazer, nem por ícone, nem pelo uso de informações textuais;

- Finalizar sessão, que apesar de ter um ícone não era de fácil visualização;

- Adicionar arquivo do slide: as telas eram confusas e as nomenclaturas utilizadas também;

- Sair da sessão: o botão sair da sessão estava com cor discreta e fora do campo de visão principal do aluno. Outra situação também é que existe um SAIR, que é para sair do ambiente Tidia-Ae, este é mais fácil de visualizar e muitas vezes foi confundido com o sair da sessão;

- Os termos em inglês dificultam o entendimento, tanto no nome da ferramenta quanto em algumas funções disponiveis;

- Para agendar sessão, o campo para indicar a hora inicial e a hora final também foi motivo de grandes problemas, já que não permite a edição da data, precisa de uma confirmação da data escolhida pressionando o 
botão APPLY o qual além de o termo está em inglês, é de difícil localização. A opção de configurar a hora também está difícil de ser localizada, pois é muito pequena e encontra-se no canto inferior esquerdo.

Ações dos usuários que foram observadas no decorrer dos testes:

- Os alunos demoravam muito tempo para encontrar a opção SAIR da sessão, primeira opção de procura era buscar o botão ao final da tela;

- Ao anexar um arquivo, foi escolhido o arquivo corretamente, mas para confirmar a escolha era necessário pressionar o botão ABRIR, esse termo não era bem assimilado para os usuários;

- Ao buscar informações em como agendar uma sessão, a primeira reação era de procurar na lista de sessões, já que contém ícones e está no centro da tela;

- Para entrar na sessão, alguns usaram a opção ENTRAR AGORA, ao invés de clicar na sessão criada pelo usuário;

- Ao tentar executar a tarefa: "Finalize a sessão criada", os usuários pressionam a opção FINALIZAR SESSÃO ATUAL, ao invés de finalizar a sessão criada;

Alguns fatos curiosos em relação ao preenchimento dos formulários e o que é observado no decorrer do teste:

- Um aluno informou no formulário de perfil do participante que não tinha nenhuma experiência com computadores, porém apresentou destreza ao utilizar o sistema e, mesmo em situações de difícil execução, como o caso do ajuste de dia e hora, aprendeu rápido após o primeiro uso.

- Um aluno informou possuir alguma experiência com computadores sentiu muita dificuldade de utilizar o sistema. Ele não conseguia diferenciar opções do browser de opções do ambiente que estava sendo testado, por exemplo, quando foi solicitado para escolher a ferramenta DigaE, essa pessoa procurou na opção no menu Ferramentas do browser.

- Um aluno que já havia cursado uma disciplina de informática básica não sabia o que era um arquivo zipado, com extensão .zip. Na hora de incluir esse arquivo a pessoa via o arquivo com mesmo nome e com o ícone de arquivo zip, mas como não sabia o que era continuava procurando e não incluía o arquivo. Só incluiu depois de muito procurar e só ter esse arquivo com o nome informado. 
- Um participante do teste sugeriu que fosse incluída a funcionalidade de um corretor ortográfico ao sistema.

Após a realização do teste, cada usuário teve que informar o que achou do sistema dando notas em relação a interface, preenchendo o formulário: "Avaliação do Sistema pelo participante"(Apêndice A) que perguntava em uma escala de 0 a 5 qual o nivel de facilidade ou dificuldade encontrado. $O$ resultado coletado foi:

- Facilidade de utilização - Não tão fácil sendo o grau 3 mais indicado com $43 \%$;

- Organização das informações - Boa, sendo o grau 4 mais indicado com $57 \%$;

- Layout das telas - Claro, com o grau 5 indicado por 57\%, seguido pelo grau 3 indicado por 43\%;

- Nomenclatura utilizada - Não tão claro, sendo o grau 3 o mais indicado com 43\%;

- Mensagens do sistema - Clara, com o grau 5 e 4 indicado por $43 \%$ dos participantes;

- Assimilação das informações - Fácil, com o grau 5 indicado pela maioria de $43 \%$.

A partir desse teste percebeu-se a necessidade de uma avaliação mais detalhada em relação a interface do sistema e os principais problemas encontrados serviram como requisitos para alterações no software.

Após a realização do teste, percebe-se que a usabilidade do sistema é boa e algumas alterações foram recomendadas para melhorar a facilidade de uso do software. Notou-se, também, que é necessário um treinamento prévio que oriente os alunos e envolvidos a conhecerem melhor o DiGaE e um nivelamento dos alunos em relação aos conhecimentos de informática básica que irão auxilia-los no manuseio do software estudado e também de outros que possam vir a serem utilizados durante o curso.

Observar os alunos utilizando o sistema e gravar suas interações e suas dificuldades que foram verbalizadas apresentam para os observadores uma possibilidade de compreender melhor o que é espero do software por parte dos usuários e nos faz conhecer melhor as dificuldades encontradas por representantes do público alvo escolhido nessa pesquisa. 


\subsection{Teste de sincronismo entre servidores Tidia-Ae}

O objetivo desse teste é ter dois servidores do Tidia-Ae que possuam a mesma estrutura, isto é, os mesmos cursos e usuários cadastrados, e que um seja a replicação do outro. A intenção é ter um servidor na capital e outro no polo. O servidor do polo possibilitaria os alunos utilizarem as ferramentas disponíveis no ambiente sem a necessidade de estarem conectado a Internet. Ao final do dia, as alterações realizadas seriam replicadas para o servidor principal, sendo atualizado diariamente e possibilitando aos professores acompanharem os alunos por meio das atividades registradas no ambiente.

O material utilizado para esse teste foram dois computadores, com a distribuição Linux Ubuntu instalada, localizados em pontos diferentes e conectados entre si por meio da Internet, sendo utilizada uma conexão da Telefônica com largura de banda (contratada) de $2 \mathrm{MB}$.

Os testes usando o Windows como sistema operacional nos servidores funcionavam somente se usasse máquina virtual e também se estivessem conectados pela Internet, porém utilizando o mesmo roteador. O teste falhou quando foram utilizados computadores em pontos distintos e conectados somente pela Internet, sendo roteadores diferentes.

\section{Taxa de Tranferência}

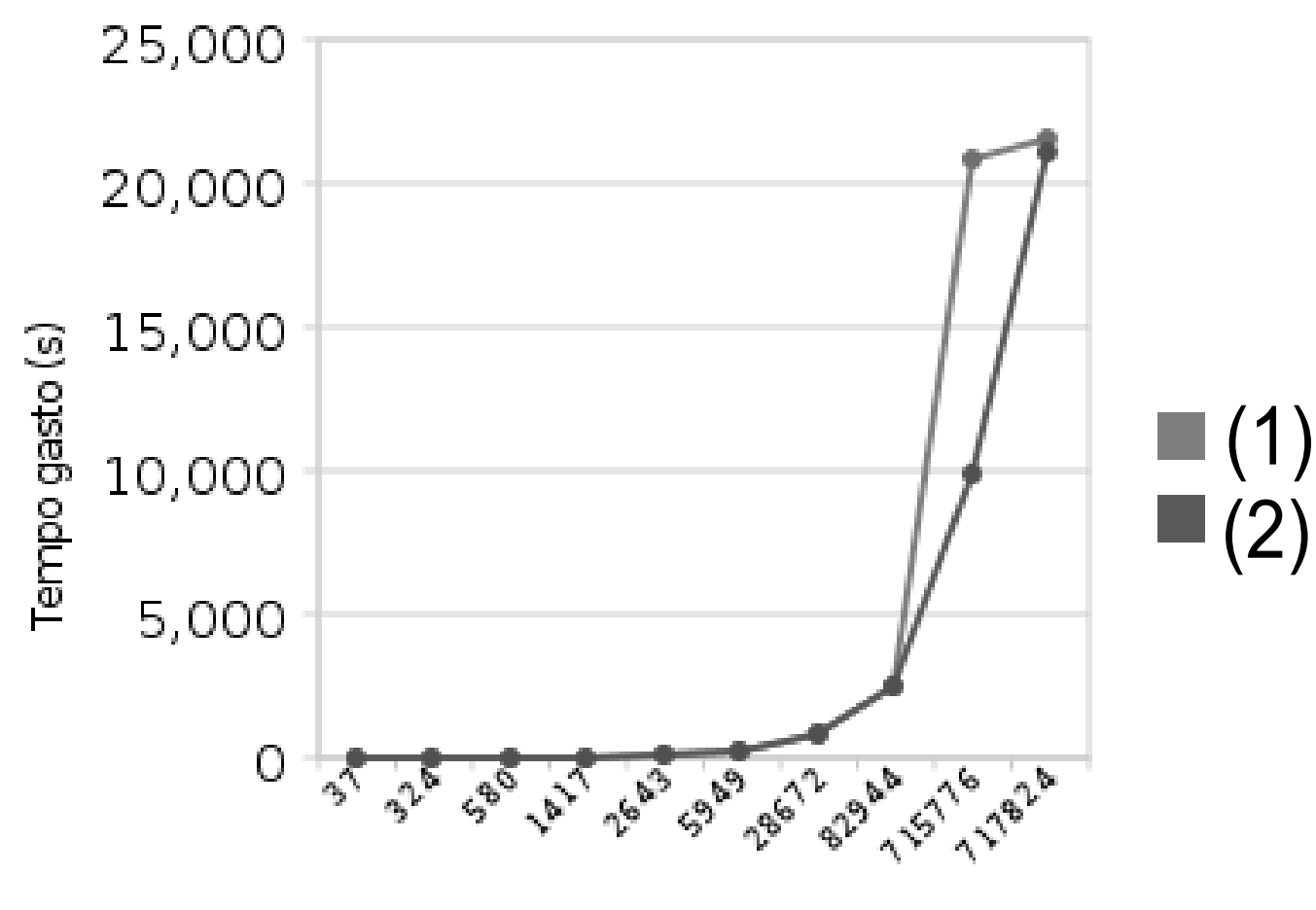

Tam. arquivo $(\mathrm{KB})$

Figura 6.1: Gráfico que representa a taxa de transferência de informações 
Para teste com sistema operaciona Linux, primeiramente foi usado o serviço de ssh para testar o tempo e a taxa de transferência, foram selecionados 10 arquivos de tamanhos diferentes e anotados os tempos. Os testes foram refeitos com uma largura de banda de 512K, sendo esta taxa informada pelo coordenador de EaD do IFAM como sendo a largura máxima disponivel nos polos onde o IFAM atua. Os resultados são mostrados no gráfico apresentado na Figura 6.1.

A linha superior (1) indica a transferência usando a largura de banda disponivel e a linha inferior (2) indica a transferência usando restrição do tamanho da largura de banda. Percebe-se que a alteração no tempo é muito pequena quando comparada com os tamanhos dos arquivos e que pouco se perde. Conclui-se que esse método é suficiente para o problema.

Para avaliar se seria possível a sincronização entre dois servidores TidiaAe localizados em pontos distintos e interligados pela Internet, foi criado um script para realizar essa tarefa de forma automática.

A partir de Manaus foi realizado o mesmo teste de transferência e sincronização, utilizando um servidor em São Carlos e outro em Manaus. Após esse teste foi constatado que o banco de dados do Tidia-Ae possui configurações que não permitem a realização desse sincronismo devido problemas porque a arquitetura do banco de dados Sakai que deixa o banco muito grande e impede que seja realizado backup do sistema. Esse problema foi relatado em fóruns: para solucionar é necessário remodelar o banco de dados e, ao invés de armazenar arquivos diretamente na base de dados, seria necessário gravar somente a indicação do caminho para encontrar o arquivo.

Investigando se o problema aconteceu por alguma configuração errada que possa ter sido feita durante a instalação soube que esse mesmo problema acontece com o servidor do Tidia-Ae que atualmente está em uso na USP e é utilizado nas disciplinas presenciais que são oferecidas na instituição.

Como a tentativa de sincronização não funcionou, foi testado também o envio de uma sessão DigaE. O objetivo desse envio seria possibilitar aos alunos enviar perguntas e dúvidas de formas não textuais, podendo aproveitar os recursos que o DigaE oferece para descrever melhor o problema que não foi entendido e ajudar o professor a saber quais são os assuntos mais críticos e que geram maiores dúvida. Com isso, seria possivel sugerir uma alternativa para o retorno das informações (dos alunos para os professores), o que é, atualmente, um dos pontos críticos dos cursos a distância.

O teste foi feito na cidade de Eirunepé e o resultado foi que o envio não foi possível, mesmo deixando aproximadamente 11 horas rodando o script de envio do pacote com as informações da sessão. O tamanho do pacote utilizado foi de 89,6 MB, esse foi o arquivo que o professor gravou sua aula, isto é, são 
15 minutos de vídeo com uso de slides apresentados na whiteboard. Como base de comparação entre a as conexões de Eirunepé e de São Carlos foram feitas medidas para saber o tempo de latência, download e upload da rede e o resultado foi o seguinte:

- Download - Eirunepé: 128kbps - São Carlos: 7.144kbps

- Upload - Eirunepé: 33kbps - São Carlos: 1.352kbps

- Latência - Eirunepé: 1.175ms - São Carlos: 110ms

Esses valores indicam que para enviar documentos multimídia de qualidade, é necessário uma conexão de Internet dedicada para este fim, como ocorre em projetos desenvolvidos, atualmente, pela SEDUC e UEA.

Com esse teste, recomenda-se o uso de uma infraestrutura de Internet que garanta uma melhor comunição entre os servidores. A atual infraestrutura não tem como atender a demanda dos cursos a distância oferecidos, causando problemas na comunicação entre professores e alunos. A solução proposta por meio de uso de softwares não foi satisfatória, sendo necessário o investimento em recursos de rede de computadores e a contratação de uma largura de banda de Internet que seja capaz de transferir dados multimídia de forma satisfatória.

Outra alternativa que poderia ser viável seria a quebra das informações a serem enviadas em pacotes pequenos e que considerem o alto tempo de latência da Internet, devido o uso de satélites, para a transmissão. Além dessa configuração, é necessária a confirmação de envio de pacotes e a indexação desses para que possam serem enviados aleatoriamente e quem receba consiga reconstruir toda a informação enviada, seguindo o modelo hoje utilizado por servidores de conteúdo como é o caso de programas como Emule ${ }^{1} \mathrm{e}$ Kazza. $^{2}$ Esses softwares utilizam a tecnologia P2P e poderia ser útil em um cenário semelhando ao apresentado nesse trabalho.

Teste como esse são importantes em uma pesquisa, pois conseguir testar um software em ambiente real é possível observar variáveis que em laboratório não são observadas com a devida atenção, sendo possível obter resultados que possam vir a serem aplicados posteriormente. No caso dessa pesquisa foi realizado testes e ajustes com o software seguindo as informações obtidas em relação a largura de banda da Internet disponibilizada, mas mesmo tendo esse cuidado não foi possível prever que não seria possível realizar a sincronização entre os servidores.

\footnotetext{
${ }^{1}$ Maiores informações disponíveis em: http://www.emule.com/

${ }^{2}$ Maiores informações em : http://www.kazaa.com/
} 


\subsection{Avaliação Heurística}

O termo "avaliação heurística"descreve um método no qual um pequeno grupo de especialistas examina uma dada interface e procura por problemas que violem alguns princípios gerais do bom projeto de interface, conforme comenta Nielsen e Molich (1990). A quantidade recomendada de sujeitos para a avaliação é de 3 a 5. Então, foram escolhidos cinco pesquisadores experientes em interação homem-computador. O critério foi escolher pessoas com envolvimento em desenvolvimento de sistemas informatizados, que tenham uma formação na área de Design, que possuam bons conhecimentos em Interação Homem- Computador e que trabalhem com aplicações para ambiente Web, no caso da avaliação da ferramenta DigaE ou que trabalhem com aplicações para TVD, no caso da avaliação da ferramenta DigaE-TV.

\section{Execução da Avaliação}

Baseado em Nielsen e Molich (1990), o plano de teste que consistiu em uma lista de heurísticas a serem avaliados, pelos sujeitos de forma subjetiva, indicando um grau de adequação do sistema em questão ao tópico sugerido. Esse grau é avaliado utilizando as seguintes classificações:

- Ruim, caso o sistema não atendesse ao requisito solicitado em nenhum momento.

- Regular: caso o sistema apresentasse uma proposta para atender o requisito solicitado, mas tenha sérios problemas.

- Bom: caso o sistema atendesse o requisito solicitado, mas ainda apresentasse algum problema.

- Ótimo: caso o sistema atendesse o requisito solicitado da melhor forma possível.

Após a avaliação desses tópicos, os avaliadores descreveram os problemas encontrados de forma livre.

A avaliação aconteceu em uma sala especialmente reservada para a execução desse teste, nela, havia um computador com a aplicação que estava sendo avaliada. No caso específico da ferramenta DigaE-TV foi utilizado a máquina virtual do GINGA e foram marcadas no teclado do computador as teclas que teriam novas funções como as existentes no controle remoto.

Cada avaliador realizou a avaliação isoladamente, a fim de não ser influenciado pelos demais. A cada um foi inicialmente explicado qual era o aplicativo a ser avaliado, o porquê da avaliação, e o fato de que eles deveriam inspecionar a interface em busca de problemas de usabilidade levando em consideração toda a sua experiência no assunto. 
A cada avaliador foi apresentada a lista de princípios heurísticos que cada um deveria observar, com uma breve explicação dos conceitos. Em seguida, os sujeitos tiveram a liberdade de expor suas dúvidas a respeito dos princípios heurísticos.

Para a realização da avaliação foi adotada a técnica de observar o sujeito e anotar as observações por ele verbalizadas, para complementar as anotações feitas pelo próprio sujeito.

Foi também pedido que os avaliadores expusessem os seus comentários, inclusive os mais informais. Em de Moraes e Rosa (2010) é dito que não é suficiente que os avaliadores simplesmente digam que não gostam de algo, solicita-se que sejam o mais específicos possíveis, listando cada problema separadamente, sempre considerando a relação com os princípios heurísticos.

A avaliação consistiu em deixar os sujeitos livres para navegarem em todo o aplicativo. Após o fim da inspeção, os sujeitos avaliaram o aplicativo preenchendo o checklist entregue a eles.

Os problemas encontrados por todos os sujeitos foram agrupados em uma única lista, seus respectivos graus de gravidade são:

- 0 - Não é encarado necessariamente como um problema de usabilidade

- 1- Problema estético. Não necessita ser corrigido, a menos que haja tempo disponível

- 2 - Problema menor de usabilidade. Baixa prioridade para a sua correção

- 3 - Problema maior de usabilidade. Alta prioridade para a sua correção

- 4 - Catástrofe de usabilidade - sua correção é imperativa antes do lançamento do produto.

\section{Resultados}

A avaliação heurística foi realizada nos sistemas: Tida-Ae, tendo enfoque na ferramenta DigaE e no DigaE-TV.

\section{Tidia-Ae}

A avaliação heurística foi realizada com 6 especialistas, sendo eles todos da área de Design de Interação e Interface Multimídia. Com o objetivo de avaliar a usabilidade e a adequação das interfaces do sistema Tidia-Ae, especialmente a ferramenta DigaE que poderá ser utilizado tanto para o professor gravar uma vídeo-aula, quanto para um aluno registrar sua dúvida.

O público alvo desse protótipo são alunos de educação a distância.

Os profissionais que participaram das avaliações foram: 
1. B. R. de A.- Graduada em Design pela UFAM, especialista em Tecnologia Educacional pela UFAM e mestre em Arte e Design pela Faculdade de Belas Artes - Universidade do Porto - Portugal. Tem experiência desde 2003 no desenvolvimento de material didático para a educação a distância. Lecionou em cursos no interior do estado do Amazonas entre 2005 e 2007. É professora de Design. Por que foi escolhida: possui vasta experiência em design educacional e conhece bem a realidade do ensino na capital e interior do estado do Amazonas.

2. A. L. B. A.- Designer formado pela Faculdade Fucapi, especialista em Design, Comunicação e Multimídia. Atualmente leciona disciplinas de ergonomia e projeto multimídia na FUCAPI. Por que foi escolhido - é designer de interface e conhece bem sobre interfaces Web.

3. F. da S. F.- Designer formado pela Universidade Federal do Amazonas, com especialização em Ergonomia e mestrado em Design pela UNESP e doutoranda em Design também pela UNESP. Por que foi escolhida: atua como designer e possui vasto conhecimento em Interação humano computador e ergonomia visual.

4. N. C. da S.- Designer, ministra disciplinas de Ergonomia, IHC e Pesquisa em Design e já cursou uma pós graduação a distância. Por que foi escolhida: possui conhecimento sobre IHC e também sobre as dificuldades de que um aluno sente ao participar de um curso a distância.

5. F. M.- Designer, especialista em Ergonomia pela UFAM. Professora do curso de Design na Fucapi e pesquisadora com ênfase em usabilidade e dispositivos móveis de um Instituto de Pesquisa. Por que foi escolhida: atua na área de designer de usabilidade e conhece a importância de um sistema ter uma boa usabilidade para aceitação dos usuários.

6. J. I.- Designer de Interação. Professor universitário do curso de Design. Por que foi escolhido: atua na área de designer de interação e trabalha principalmente com interfaces Web.

Após avaliar o sistema baseado nas heurísticas de Nielsen, foram obtidos os problemas encontrados e agrupados em uma única lista. Em seguida, essa lista foi enviada aos avaliadores para informar qual o grau de gravidade de cada problema. O grau de gravidade de cada problema encontrado poderia ser classificado nas seguintes categorias:

- 0 - Não há consenso quanto a problema de usabilidade

- 1 - Problema somente cosmético - Precisa ser corrigido somente se sobrar tempo no projeto; 
- 2 - Problema menor de usabilidade - Corrigi-lo deve ter baixa prioridade;

- 3 - Problema Grave de usabilidade - Importante corrigi-lo tem alta prioridade;

- 4 - Catástrofe de usabilidade - Sua correção é imperativa antes do lançamento do produto.

Os problemas encontrados e agrupados segundo o seu grau de gravidade foram:

Gravidade 0 : Não foram encontrados problemas nesse nível de gravidade.

Gravidade 1 : $\quad$ Problemas com os ícones, não seguem o mesmo padrão de tamanho e forma gráfica;

- Não ter outra diferenciação das sessões além do texto, seria interessante ter cores ou ícones para facilitar a assimilação das informações;

- Excesso de informações na lista de sessões finalizadas;

- A whiteboard não dimensiona automaticamente, tem que fazer os ajustes manualmente;

Gravidade 2 : $\quad$ - A identificação da disciplina está difícil de localizar;

- Os termos em inglês dificultam o entendimento;

- O contraste das cores é muito discreto, dificultando a percepção, por exemplo, as cores das abas com o fundo azul escuro;

- O contraste das cores é muito discreto, dificultando a percepção, por exemplo, as opções de agendar sessão, entrar agora, usam cores que não destacam e que demora a encontrar uma opção;

- Ao invés de mostrar todas as seções em uma lista única, colocar somente as ultimas criadas, agendadas e finalizadas, evitando assim muita informação que possa atrapalhar. Sendo necessário criar uma opção como "mostrar tudo";

- Falta de alinhamento entre as colunas de cada categoria de sessão;

- Algumas opções não possuem ícones, sendo necessário para facilitar achar e assimilar a informação, por exemplo, VOLTAR, DOWNLOAD, WHITEBOARD;

- A ferramenta DigaE não possui ícone;

- Não está claro como deve entrar na sessão, confunde com a opção visualizar e com o ícone de lupa, ao invés de clicar no link com o nome da sessão; 
- Quando entrar na opção de Editar Sessão, o botão para confirmar as alterações feitas está com o seguinte rótulo: "Editar Sessão", mudar para "Salvar";

- Problema na data/hora da sessão! Não possibilita o ajuste de data/hora na própria caixa de informações dos mesmos. Confusão para visualizar a hora inicial e hora final, por exemplo, editar a hora final pensando que esta editando a hora inicial. A etapa de informar a hora inicial está no início do formulário, sendo necessário o preenchimento de muitas informações após esta, podendo então a hora está desatualizada ;

- Muitos passos para agendar uma sessão;

- O botão de sair da sessão do DigaE está de difícil visualização;

- O sistema não deixou claro ao iniciar uma sessão que já estava gravando o vídeo;

- Problema no chat, não digitou de primeira, precisou desmarcar a seleção da opção de rolagem para funcionar;

Gravidade 3 : $\quad$ - Falta de organização hierárquica da interface;

- Termos dos links não são apropriados para o público;

- A rotulação dos menus e botões usam termos que dificultam a tomada de decisão.;

- Dificuldade de perceber uma barra de ferramentas do lado esquerdo da tela;

- Após sair da área da disciplina, mudando a opção da aba superior, a sessão continua funcionando;

- Dificuldade para voltar na tela principal do DigaE, depois de estar em algum subnível da ferramenta, por exemplo, estar na opção de editar sessão e querer voltar para a área de listagens de sessões;

- "Entrar Agora"não indica exatamente o que poderá ser feito nessa opção;

- "Finalizar sessão atual"deixa entender que poderá finalizar a sessão que foi criada, ao invés de finalizar a sessão default que é criada automaticamente pelo sistema;

- Falta de informação clara sobre como fazer o download de uma sessão finalizada;

- Problema na data/hora da sessão. Duplo clique não funciona para a data, o usuário já está acostumado com sistemas assim. Difícil visualizar a hora, muito pequeno e escondido; 
- O sistema não informa se o arquivo Duvidas.zip foi anexado corretamente;

- As telas de anexar arquivo são confusas, possuem dois botões com a mesma função e com terminologia que não indica corretamente o que fazer;

- Na etapa de anexar arquivo não consta nenhuma informação sobre o formato do arquivo que o sistema aceita;

- Na hora de Agendar sessão, não tem uma opção de local, mas não pode fazer nada dessa opção;

- O sistema não deixou claro que quando finalizou a sessão foram salvas as alterações feitas e o vídeo;

- Ao entrar na sessão, o usuário não sabe se entrou definitivamente ou se está editando;

- Falta da opção de edição do vídeo como parar, pausar;

- Ao tentar carregar um arquivo usando a ferramenta do chat, a mensagem ficou parte escondida atrás da whiteboard;

- Na whiteboard, não é possível reverter as opções de erro, por exemplo, excluir uma opção da barra de edição e não conseguir adicionala novamente a opção.

Gravidade 4 : - Os títulos das duas primeiras listas de seções estão com o mesmo nome, ambas estão escrito: "Sessões agendadas";

- Comunicação com o usuário está confusa, por exemplo, a frase :"Olá Aluno,"está entre as listas de sessão agendada, sendo difícil a sua visualização e tornando confusa a compreensão de sua função devido a informação estar fora de contexto;

- Problema na data/hora da sessão! Exige confirmação utilizando o botão APPLY, termo em inglês;

As sugestões de melhorias propostas pelos especialistas foram:

- Acrescentar ícones em todas as ferramentas utilizadas no Tidia-Ae, mantendo assim uma padronização;

- Colocar o botão SAIR (de uma sessão) em uma área de maior destaque;

- Utilizar uma ferramenta de calendário mais semelhante as utilizadas em outros sistemas, como o de compra de passagens aéreas, que não necessita de confirmação (APPLY) e pode editar diretamente na caixa de texto, se preferir. Seria interessante também separar as informações da data e de hora; 
- Traduzir todos os termos em inglês utilizado no sistema;

- Ter um ícone para Download das sessões finalizadas, assim como existe para editar e finalizar sessão;

- Modificar as cores do sistema a fim de obter maior contraste e facilitar a localização das informações, por exemplo, nas abas das disciplinas está muito escuro tanto o fundo quanto a cor do texto;

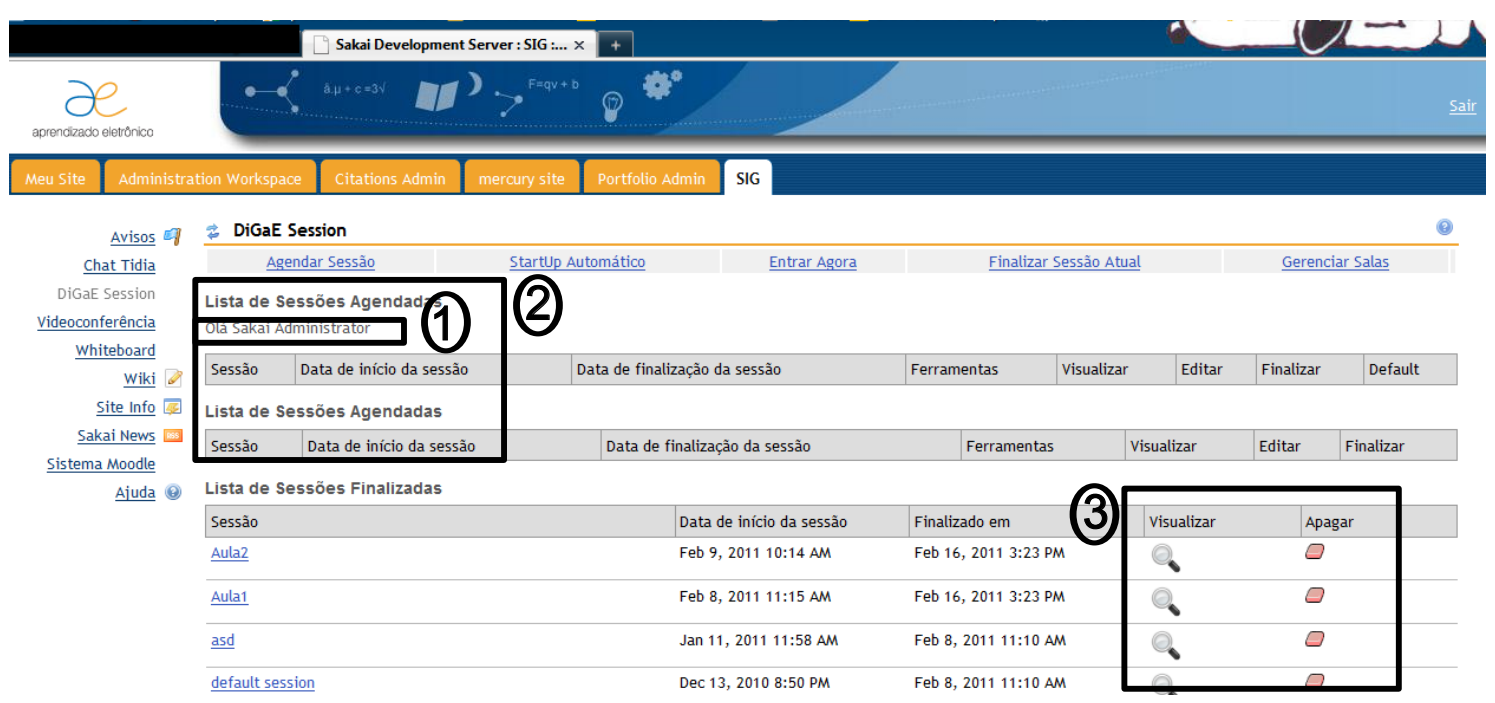

Figura 6.2: Ferramenta DigaE antes da realização das avaliações

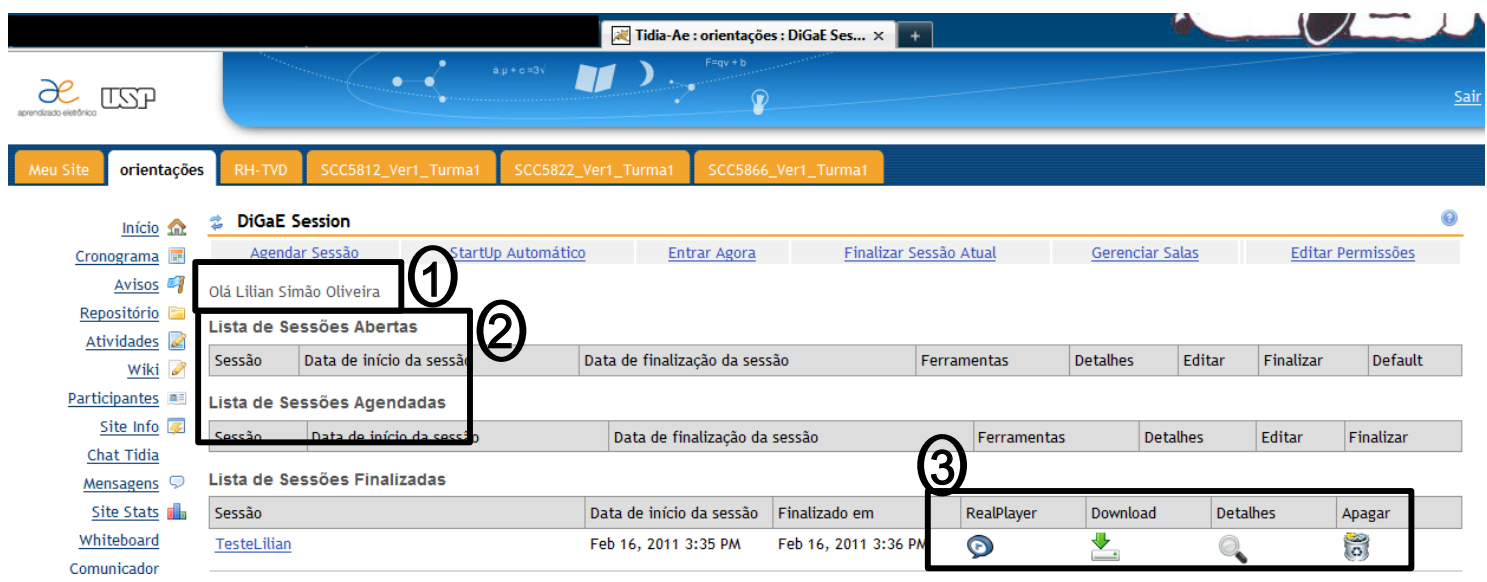

Figura 6.3: Ferramenta DigaE com algumas alterações sugeridas após a realização das avaliações

Como resultado a avaliação heurística usando o DiGaE, foram realizadas alterações na ferramenta conforme as sugestões obtidas pelos especialistas que realizaram a avaliação. Na Figura 6.2 (como era antes das avaliações) e na Figura 6.3 (com algumas alterações sugeridas). Na Figura 6.2, na área 1, o nome do usuário é apresentado fora de contexto e sem estar dentro de uma hierarquia das informações. Já na Figura 6.3, na área 1, é apresentado dentro do contexto da ferramenta DigaE. Também foram corrigidos na área 2 das 
Figuras os nomes das sessões que estavam com nomes iguais, sem identificar corretamente a qual grupo uma sessão pertencia. Na área 3, que é a área de informações e das funcionalidades de cada sessão, foram acrescentados: ícones para indicar melhor como fazer o download de uma sessão, e para a funcionalidade de assistir uma sessão usando o RealPlayer, sem a necessidade de fazer download, além disso, mudou o termo utilizado para ver maiores informações da sessão de "Visualizar"para "Detalhes".

\section{DigaE-TV}

A avaliação heurística foi realizada com 6 especialistas, sendo eles todos da área de Design de Interação e Interface Multimídia: o objetivo foi avaliar a usabilidade e a adequação das interfaces do protótipo do DigaE-TV.

O público alvo desse protótipo são alunos de ensino a distância que poderiam assistir as aulas gravadas pelo professor de uma disciplina que gravou a sua aula usando o sistema DigaE pela Web. Posteriormente a sessão da aula salva foi exportada para o padrão SMIL e, a seguir, as mídias foram processadas para as adaptações para o padrão brasileiro de TVD e o middleware GINGA. No caso de transmissão via TVD esse conteúdo seria transmitido por uma emissora de TV e os alunos poderiam assistir às aulas em horários definidos na programação da emissora. Os alunos poderiam assistir em uma sala de aula, em um polo, junto com os demais alunos do curso ou sozinho, em sua residência.

Os profissionais que participaram das avaliações foram:

1. D. M. F.- Designer formada pela Universidade Federal do Amazonas, trabalha no Instituto Nokia de Tecnologia no Usability lab, onde trabalha com projetos de User Experience Evolution e avaliações heurísticas de usabilidade com mobiles. Por que foi escolhida: possui experiência como Designer de Interação e conhece bem os procedimentos de um teste. heurístico com a finalidade de obter o grau de usabilidade de um produto.

2. W. S. P.- Designer formado pela Universidade Federal do Amazonas. Líder de projetos do stream "Service Experience"com foco em desenvolvimento e pesquisa de aplicativos para dispositivos móveis do Instituto Nokia de Tecnologia. Por que foi escolhido: trabalha como Designer de Interação atuando principalmente no desenvolvimento de novos produtos e serviços.

3. A. B. D.- Designer formado pela Universidade Federal do Amazonas, com especialização em Multimídia e possui experiência profissional em projetos Web, arquitetura de informação e designer de interação. Por que foi escolhido: atua como designer de interação e possui experiência em projetos de aplicações multimídia. 
4. W. S.- Designer de Interação para aplicativos móveis e TV Digital no Instituto Nokia de Tecnologia. Por que foi escolhido: possui conhecimento sobre as características e limitações de aplicações para TV e atua como designer de interação.

5. M. S. F. de F.- Designer formada pela Universidade Federal do Amazonas, especialista em comunicação empresarial e marketing. Por que foi escolhida: atua na área de designer de interfaces e já trabalhou em um projeto de uma aplicação para a TV Digital.

6. B. R. de A. - Graduada em Design pela UFAM, especialista em Tecnologia Educacional pela UFAM e mestre em Arte e Design pela Faculdade de Belas Artes - Universidade do Porto - Portugal. Tem experiência desde 2003 no desenvolvimento de material didático para a educação a distância. Lecionou em cursos no interior do estado do Amazonas entre 2005 e 2007. É professora de Design. Por que foi escolhida: possui vasta experiência em design educacional e conhece bem a realidade do ensino na capital e interior do estado do Amazonas.

Os problemas encontrados e agrupados segundo o seu grau de gravidade foram:

Gravidade 0 : $\quad$ - Após escolher uma opção o sistema não inicia a partir do primeiro ponto de interação marcado. É necessário ainda selecionar o ponto e pressionar ENTER;

- Os temas dos slides, como Mapas, GPS etc, não estão relacionados diretamente com a ferramenta da whiteboard e sim com o conteúdo da aula. Então deveria estar em outro nível, ao invés de estar associado a ferramenta whiteboard.

Gravidade 1 : Os termos como "professou falou", precisa ser mais formal e ter o significado mais intuitivo.

Gravidade 2 : $\quad$ O ícone seta para cima e para baixo do menu transmitiu a informação que existia um sub nível associado ao invés de indicar quais teclas o usuário poderia utilizar;

- Não existe opção de apagar a seleção escolhida, caso tenha mudado de ideia ou escolhido errado uma opção no Menu;

- Falta de uma sinalização que existe mais opções além do que aparece na tela, por exemplo, na opção de lousa. Sugestão seria existir uma barra de rolagem indicando que existem mais opções que não foram apresentadas; 
- A área de feedback para o usuário não está muito visível, passando até despercebido. Exemplo a área que informa qual opção foi escolhida no menu;

- Funções lógicas causam confusão. Além dos termos estarem em inglês, o conceito de operadores lógicos não são para usuários comuns;

- Possibilitar mudanças no layout da aplicação, por exemplo, sumir com o vídeo e expandir a ferramenta whiteboard e ficar só ouvindo o professor;

- Os sub níveis do menu são apresentados da mesma maneira dos níveis anteriores. Precisa enfatizar mais qual opção e nível que o usuário se encontra ;

Gravidade 3 : - A falta de legenda a respeito de opções como Start e Stop;

- Ao entrar no MENU as opções estão desativadas e estão sem foco ;

- Falta informar ao usuário o que seria apresentado em cada ponto de interação informado. Por exemplo, quando passar por um determinado ponto mostrar uma imagem referente ao conteúdo para o usuário definir se é isso que ele deseja.

Gravidade 4 : - Erro ao tentar usar uma função que não está habilitada, por exemplo, o chat. Deveria estar visualmente desabilitado ou não aparecer;

- Possibilitar operações comuns de vídeo, como pause, avançar, retroceder etc;

- O menu de ajuda não foi encontrado;

- Não tem nenhuma indicação a respeito de como navegar e selecionar os pontos de interação na linha do tempo;

- O sistema não informa o tempo atual e o tempo de duração da aula.

As melhorias sugeridas foram:

- Desenvolver um vídeo inicial para apresentar o programa e ensinar como poderá ser utilizado. Isso poderá ser feito como uma propaganda e apresentador ensinariam as funcionalidades e os modos de uso do sistema;

- Em cada ponto de interação criado na linha do tempo apresentar uma "foto"do instante, quando for selecionado. Isto poderá ajudar o usuário a lembrar o que foi apresentado naquele instante e auxilia-lo a escolher o ponto exato em que procura.

- Possibilitar o usuário manipular o vídeo com opções já conhecidas como avançar, 
- Após escolher uma opção do menu, sincronizar automaticamente para o primeiro ponto apresento, sem a necessidade de confirmação do usuário ao pressionar o botão ENTER. Isso iria reduzir a carga de tarefas do usuário.

- Gerar uma recomendação para os professores prepararem as suas aulas. Principalmente sobre como gerar suas apresentações, sugerindo que use pouco texto, o tamanho de fonte recomendada para posterior leitura na TV etc.

\subsection{Considerações Finais}

Após efetuar diversas avaliações e observar o uso dos softwares selecionados pelos alunos, que representam o público alvo, e por especialistas, pode-se obter uma lista de melhorias para os softwares estudados. Percebe-se que apesar dos esforços de melhorar os recursos através de técnicas de software é impressindivel a melhoria e o investimento na infraestrutura de Internet. Um teste complementa o outro, o teste de usabilidade tenta compreender melhor as dificuldades encontradas pelos alunos, porém, os usuários não sabem descrever com clareza qual é o problema, ele somente aponta que existe problema em algum ponto específico do sistema. Para conhecer melhor os problemas da interface, utilizou da tecnica de avaliação heurísticas, que especialistas apontam os problemas que provavelmente os usuários irão sentir dificuldade e também sugerem solução de como melhorar a interface e as interações do sistema. Os testes de sincronimo foi importante para validar os testes efetuados em laboratório e foi possivel perceber que nem sempre é possivel prever o comportamento de aplicação em uso num cenário real e no dia-a-dia.

A ferrementa DiGaE, apresentou-se como uma ferramenta que pode vir a ser utilizada para a criação de vídeo-aula, pois sua funcionalidade é intuitiva e conta com recursos que os professores estão acostumados a utilizar como a lousa. A utilização da ferramenta DiGaE por parte dos professores para a criação das alunas poderá acarretar na redução de custos, visto que não será necessário todo aparato de estúdio profissional para a gravação da aula e também redução de tempo. O professor que realizou a gravação da aula que foi utilizada nos experimentos desse trabalho, gostou da ferramenta devido a sua facilidade, já que foi explicado em 5 minutos como funcionava e em seguida ele gravou uma aula teste e logo em seguida a aula que foi apresentada aos alunos. No cenário utilizado não foi necessário a edição da aula, mas é uma sugestão para trabalhos futuros a possibilidade de edição da vídeoaula. Com a edição do conteúdo multimídia será possível cortar trechos em que houveram algum problema sem ser necessário gravar todo o conteúdo 
novamente.

A ferramenta DiGaE-TV foi aceita como uma alternativa viável para oferecer conteúdos multimídia para os alunos que não conseguem acessar esses conteúdos diretamente pela Internet. 


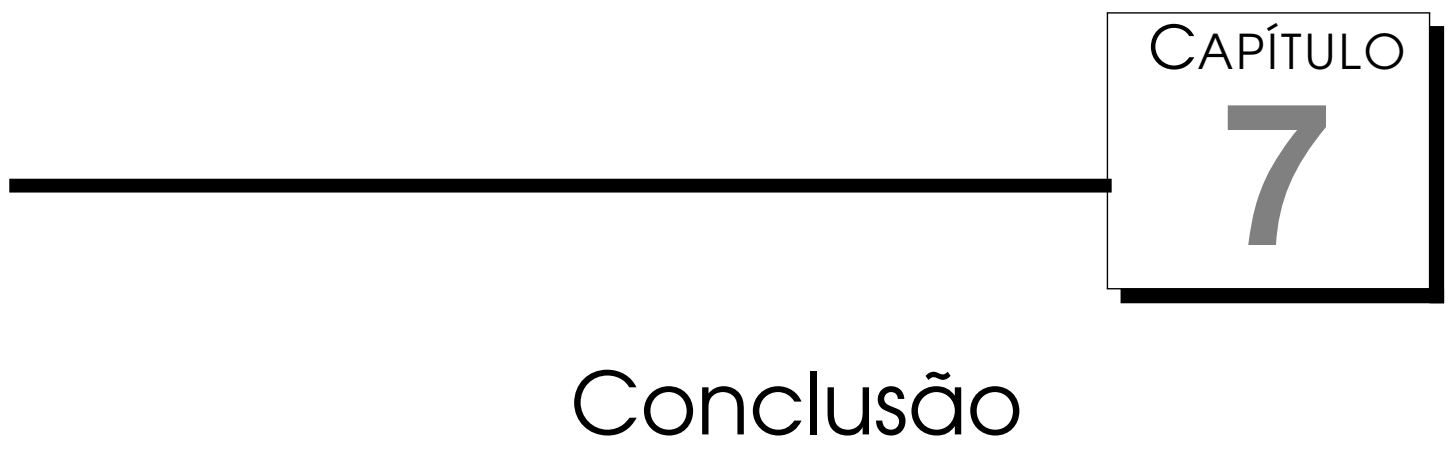

$\mathrm{Na}$ introdução deste trabalho foi especificado o problema que foi estudado no decorrer desta pesquisa. O problema em questão caracteriza-se pela dificuldade encontrada pelos professores e alunos em se comunicarem em cursos a distância e, também, em escolher ferramentas de softwares adequadas que auxiliem na tarefa de melhorar a qualidade da educação. É claro que medir o nível de aprendizagem não é algo trivial e que essa pesquisa, embora tenhamos alcançado os resultados expostos neste trabalho, não permite afirmar ou negar determinados níveis de aprendizagem. Além disso, embora seja de extrema importância, essa análise não faz parte dos nossos objetivos principais. Seria necessário realizar uma outra pesquisa na área de educação. Porém, este trabalho procurou entender o real problema enfrentado pelos envolvidos no processo de um curso oferecido a distância, por meio do estudo de caso do curso oferecido pelo IFAM.

Os cursos a distância oferecidos por instituições que estão localizadas no estado do Amazonas apresentam certas especificidades, porém, servem como parâmetro para delimitar o problema de pesquisa e focar em um cenário que pôde ser estudado por diversos ângulos. Essa escolha nos possibilitou observar os alunos em seu ambiente de estudos e obter conclusões a cerca das dificuldades enfrentadas e das vantagens do uso de recursos multimídias para agregar valor aos materiais didáticos oferecidos nos cursos. Ademais, foram relatadas conversas feitas com um professor que vivencia a realidade da região que faz uso da educação a distância como meio de minimizar a problemática da educação em uma região isolada geograficamente. Nesse cenário foi possível o uso de softwares que podem ajudar a melhorar a qualidade do ensino oferecido. 
Para conhecer melhor o que já foi feito e as práticas que já estão dando certo no estado, foi realizado um levantamento a cerca das instituições que oferecem cursos a distância. O principal objetivo desse levantamento foi obter diretrizes que, por fim, guiaram o trabalho, possibilitando a proposição de soluções para os que apresentavam dificuldades em atender a contento os alunos matriculados nos cursos oferecidos.

Após esse levantamento, verificou-se que a Internet hoje é o principal meio de comunicação entre professores e alunos, porém, existem algumas regiões onde não é possível garantir uma qualidade suficiente para acessar todos os conteúdos disponibilizados a contento. Devido a isso, fez-se necessária a busca de alternativas que sejam viáveis e eficientes. Foi efetuado, então, um levantamento bibliográfico a respeito dos trabalhos desenvolvidos na área de educação sobre os padrões utilizados nos ambientes Web que apoiam a EaD. Também foram estudados projetos que utilizam a TV como ferramenta para a difusão do conhecimento, visto que esse equipamento é acessivel a todos os brasileiros não importando a classe social em que o indivíduo se encontre nem a região na qual reside.

Tendo em vista o fato de que hoje a TV Digital já uma realidade, este trabalho também pesquisou sobre o uso da TV Digital interativa como mais uma possibilidade de ferramenta para apoio a educação a distância. No cenário da TVDi alguns autores apontaram para nichos como a geração automática de conteúdo educativo a partir de um LMS e a sincronização desses conteúdos, alternativas essas que pretendem aproveitar esse conteúdo, que hoje já é gerado na Web, usando padrões estabelecidos para a formatação de conteúdo educacional. Esse é o caso de objetos de aprendizagem como, por exemplo, o SCORM, para a criação de conteúdos multimídias interativos que virão a ser apresentados em uma TV para os alunos em um horário específico, permitindo que eles assistam de suas casas ou de uma escola na qual hajs o polo em que é oferecido o curso. Esses aplicativos desenvolvidos para o ambiente de TVDi são conhecidos como t-learning e vão muito além da adaptação de formatos de mídias da Web para TV. Para conseguir oferecer uma programação educativa de qualidade que una as vantagens que a TVDi proporciona com as orientações pedagógicas que acompanham os conteúdos gerados em ambientes de e-learning, faz-se necessária a preocupação com o usuário, por isso, trabalhos apresentam diretrizes para a criação de soluções que atendam as necessidades dos usuários proporcionando satisfação e eficiência na hora de utilizar o sistema proposto.

Após conhecer a realidade dos cursos a distância e seguindo autores que apresentaram propostas e soluções a cerca da integração entre a TV e com a Web a fim de proporcionar aos estudantes inúmeras possibilidades de acesso 
ao conteúdo educativo. Este trabalho selecionou o LMS Tidia-Ae que foi desenvolvido com o intuito de apoiar o ensino presencial e a distância, estudando os desdobramentos oferecidos pela ferramenta DigaE e aplicando o seu uso em um cenário de um curso a distância.

Para conhecer as funcionalidades que eram aplicáveis e as que precisavam de mais algumas adaptações para ser melhores usufruídas, foram efetuados testes com alunos do curso a distância de meio ambiente que é ofertado pelo Instituto Federal do Amazonas (IFAM). Também foram avaliados por especialistas em usabilidade a fim de obter dados que pudessem contribuir com alterações no software que garantisse a facilidade de uso pelo público alvo. Esse cenário foi escolhido devido as restrições impostas pela realidade local, servindo como base para recomendações tanto curso a distância de regiões com restrições semelhantes quanto para locais que não tenham tanto problemas de isolamento geográfico, mas que possam aproveitar das melhorias sugeridas neste projeto. Sendo então as contribuições obtidas proveniente de um cenário real de educação a distância.

\subsection{Contribuições e limitações do projeto}

De forma geral, o presente trabalho apresenta três contribuições:

A primeira contribuição foi a de apresentar uma possibilidade de uso da TVDi como ferramenta de apoio à educação a distância. Sendo esta uma possibilidade de oferecer conteúdos multimídia de qualidade para alunos que possuam restrições de acesso à Internet e que não consigam visualizar vídeos de forma satisfatória nos seus computadores. Esses fatos demonstram as potencialidades dessa nova mídia e incentivam o seu uso na área educacional, possibilitando, assim, atingir cenários mais abrangentes de uso em comparação à Internet.

A segunda contribuição foi de propor o uso ao professor de uma ferramenta de software open source que possibilitasse a criação de vídeo-aula de forma fácil e intuitiva, fazendo com que os custos da preparação desses materiais sejam reduzidos e o tempo empregado também quando comparados com esforços que exigem estúdios profissionais. Essa ferramenta proporciona o acesso a todos os interessados, independente de sua área de atuação e possibilita agilizar o processo de criação de materiais didáticos para os alunos. Essa vantagem de diminuir o tempo de preparação de vídeo aula também contribui para locais que possuem problemas logísticos e que precisam concluir a preparação das disciplinas muito tempo antes do início dessas.

A terceira contribuição foi expor as necessidades dos envolvidos no processo de um curso a distância, que muitas vezes não são vistas com clareza, 
já que relatos assim nem sempre são descritos em trabalhos relacionados. Essa situação enfatiza que a escolha de uma ferramenta de apoio vai muito além de selecionar funcionalidades, e sim de proporcionar diversos meios de oferecer aos alunos interessados possibilidades de comunicação e de acesso a conteúdos multimídia.

\subsection{Trabalhos Futuros}

Novas pesquisas podem ser desenvolvidas em diversos nichos como:

- Geração de vídeo-aula: a ferramenta DigaE apresentou possibilidades viáveis de auxiliar os professores na criação de vídeos aulas de modo rápido e fácil. Porém, algumas melhorias podem ser implementadas como a criação de uma ferramenta de edição do vídeo final gerado, possibilitando assim alguns ajustes como cortes e acréscimos de maneira rápida, sem que seja necessário salvar outra aula desde o início e sim fazer o corte de alguns pedaços em que o professor ficou em silêncio ou falou alguma coisa enganado.

- O DigaE-TV foi desenvolvido seguindo os padrões estabelecidos pelas normas do GINGA, porém para esse software ser utilizado no mercado de TVDi, fazem-se necessários alguns testes de campo utilizando um settop-box que tenha o middleware certificado por uma instituição que garanta a sua adequação à norma. Esse teste é necessário para a detecção de falhas não percebidas fazendo uso de simuladores.

- A correção de todas as sugestões de melhorias dos sistemas Tidia-Ae e DigaE-TV obtidas por meio das avaliações heurísticas e de usabilidade, a fim de aprimorar as interfaces e oferecer ao público alvo sistemas que sejam eficientes e de fácil uso para as funcionalidades a que se propõem.

- Os estudos realizados não garantiram um meio de retorno eficiente das informações (aluno-professor) devido a limitações técnicas expostas no trabalho. Porém, esse retorno das dúvidas é um dos pontos primordiais para garantir a qualidade do ensino. Surge, então, a necessidade de maiores estudos que propõem essa volta de forma eficaz e segura, seja ela, por meio da TV ou por meio de softwares que se adaptem melhor a cenários com restrições como o apresentado neste trabalho.

- Estudos na área de pedagogia também apresentam-se como uma possibilidade, no sentido de auxiliar os professores na criação de um roteiro de aula utilizando as ferramentas aqui exploradas e que atendam as necessidades dos alunos que participam de cursos na modalidade a distância. 
Este trabalho, então, é apenas um começo de inúmeras possibilidades que poderão ser exploradas. Mesmo que o cenário seja restrito, os alunos estão sedentos de alternativas viáveis que os auxiliem a obter novas capacitações e que agreguem conhecimento que de outro modo não seria possivel. Os professores, técnicos e coordenadores envolvidos nesse processo também se esforçam para oferecer as melhores oportunidades para os estudantes, se desdobrando para solucionar os desafios apresentados, não só pedagógicos como muitas vezes em pontos que nem poderiam imaginar, como problemas logísticos devido as secas históricas, isolamentos geográficos, problemas de energia, etc. 


\section{Referências Bibliográficas}

Aarreniemi-Jokipelto e Paivi. Instant messaging in informal learning via interactive television: online communities among children in a. Comput. Entertain., 5, April 2007. ISSN 1544-3574. doi: http://doi.acm.org/10.1145/ 1279540.1279549 .

ABNT 15606. ABNT NBR 15606-2 - Digital terrestrial television Data coding and transmission specification for digital broadcasting Part 2: Ginga-NCL for fixed and mobile receivers - XML application language for application coding, Novembro 2007. Corrected version 2 2009.04.17. Available at http://www.dtv.org.br/download/enen/ABNTNBR15606_2D2_2007Ing_2008Vc2_2009.pdf.

L. Agner. Arquitetura de informação e governo eletrônico. Tese de doutorado, PUC-Rio, 2007.

H. S. Al-Khalifa e H. Davis. The evolution of metadata from standards to semantics in E-learning applications. In Proceedings of the Seventeenth Conference on Hypertext and Hypermedia, Odense, Denmark, 2006.

L. Alves, R. Kulesza, F. S. da Silva, P. Jucá, e G. Bressan. Análise comparativa de metadados em TV digital. Simpósio Brasileiro de Redes de Computadores - SBRC, 2006.

J. A. Andreata. InteraTV: Um Portal para Aplicações Colaborativas em TV Digital Interativa Utilizando a Plataforma MHP. Dissertação de mestrado, Universidade Federal de Santa Catarina, 2006.

L. Anido-Rifón. Accessibility and Supporting Technologies in M-Learning Standardization. In Proceedings of the Third International Conference on Systems, páginas 162-167, Washington, DC, USA, 2008. IEEE Computer Society. ISBN 978-0-7695-3105-2. doi: 10.1109/ICONS.2008.75. 
F. Arantes, C. Moraes, e S. Silva. Where and with whom do you wanna meet? Session-based collaborative work. In Proceedings of the 2008 ACM Symposium on Applied Computing, WebMedia'10, páginas 123-130. ACM, 2010. ISBN 978-1-59593-753-7.

E. Barrére e P. M. Leite. Especificação de um Mecanismo de Integração entre o Moodle e uma Aplicação de TV Digital Interativa. XX Simpósio Brasileiro de Informática na Educação, Florianópolis - SC, 2009.

BBC. BBC. British Broadcasting Corporation. Disponível em: http://www.bbc.co.uk ., 2011. ültimo acesso em 01 de fevereiro de 2011.

F. R. Belda. Um modelo estrutural de conteúdos educativos para Televisão Digital Interativa. Tese de doutorado, Universidade de São Paulo, 2009.

F. Bellotti, J. Mikulecka, e L. Napoletano. Designing a Constructionistic Framework for T-Learning. In W. Nejdl e K. Tochtermann, editores, Innovative Approaches for Learning and Knowledge Sharing, volume 4227 of Lecture Notes in Computer Science, páginas 549-554. Springer Berlin Heidelberg, 2006.

F. Bellotti, S. Vrochidis, e I. Tsampoulatidis. A Learning Oriented Technological Framework for iDTV. In Proceedings of the 2008 International Conference on Automated solutions for Cross Media Content and Multi-channel Distribution, páginas 79-86, Washington, DC, USA, 2008. IEEE Computer Society. ISBN 978-0-7695-3406-0. doi: 10.1109/AXMEDIS.2008.30.

S. Buchinger, S. Kriglstein, e H. Hlavacs. A comprehensive view on user studies: survey and open issues for mobile tv. In Proceedings of the Seventh European Conference on European Interactive Television Conference, EuroITV '09, páginas 179-188, New York, NY, USA, 2009. ACM. ISBN 978-1-60558340-2. doi: http://doi.acm.org/10.1145/1542084.1542121.

S. Carliner e P. Shank. The E-Learning Handbook: A Comprehensive Guide to Online Learning. Pfeiffer, 2008.

R. G. Cattelan, C. Teixeira, e H. Ribas. Inkteractors: interacting with digital ink. In Proceedings of the 2008 ACM Symposium on Applied Somputing, SAC '08, páginas 1246-1251, New York, NY, USA, 2008. ACM. ISBN 978-159593-753-7. doi: http://doi.acm.org/10.1145/1363686.1363973.

C. S. F. Celes e C. T. Souza. Estilos Arquiteturais de Software na Construção de Objetos de Aprendizagem para a TV Digital Interativa. XVIII Simposio Brasileiro de Informática na Educação (SBIE), páginas 1-10, 2007. 
K. Chorianopoulos e G. Lekakos. Learn and play with interactive TV. Comput. Entertain., 5, April 2007. ISSN 1544-3574. doi: http://doi.acm.org/10. $1145 / 1279540.1279544$.

CMM. Colégio militar de manaus $(\mathrm{cmm})$ - seção de ensino a distância. Disponível em: http://www.eadcmm.com/portal/, 2010. Último acesso em 01 de fevereiro de 2010.

M. M. d. O. Coelho. Educação a distância: uma alternativa para a formação do professor leigo rural no Estado do Amazonas (1971-1998). UFAM, 2007.

F. D. S. Colace, M. Ritrovato, e P. Mascambruno. From e-learning to t-learning. 3rd International Conference on Information and Communication Technologies: From Theory to Applications, ICTTA 2008., 2008.

C. Collazos, C. Rusu, e J. Arciniegas. Designing and evaluating interactive television from a usability perspective. In Proceedings of the 2009 Second International Conferences on Advances in Computer-Human Interactions, ACHI '09, páginas 381-385, Washington, DC, USA, 2009. IEEE Computer Society. ISBN 978-0-7695-3529-6. doi: http://dx.doi.org/10.1109/ACHI.2009.22.

J. R. Costa e V. F. Lucena Jr. An Educational Component-Based Digital TV Middleware for the Brazilian's System. In Proceedings of the 3rd International Conference on Technologies for E-Learning and Digital Entertainment, Edutainment '08, páginas 41-51, Berlin, Heidelberg, 2008. Springer-Verlag. ISBN 978-3-540-69734-3. doi: http://dx.doi.org/10. 1007/978-3-540-69736-7_5.

Cultura. TV Cultura - Fundação Padre Anchieta - Disponivel em: http://www.tvcultura.com.br/ - Último acesso em 01 de fevereiro de 2011, 2011. URL http://www.tvcultura.com.br/.

M. J. Damásio. Uses of Interactive Television on Educational Settings: Evaluating the Media Impact. In J. Masthof, R. Griffiths, e L. Pemberton, editores, Proceedings of the 1st European Conference on Interactive Television: from Viewers to Actors?, 2003.

F. de J. L. Gomes e R. M. Sousa. TV Digital Interativa e o Desenvolvimento Neuropsicomotor de Crianças com Síndrome de Down. XV Simpósio Brasileiro de Sistemas Multimídia e Web (Webmedia 2009), páginas 1-2, 2009.

A. de Moraes e J. G. S. Rosa. Avaliação e Projeto no Design de Interfaces. 2AB, 2010.

A. Disessa. Changing Minds: Computers, Learning, and Literacy. The MIT Press, Cambridge, MA, April 2000. ISBN 0262041804. 
D. T. dos Santos, D. T. do Vale, e L. G. P. Meloni. Digital TV and Distance Learning: Potentials and Limitations. In Frontiers in Education Conference, 36th Annual, páginas 1-6, March 2007.

M. Dougiamas e P. Taylor. Interpretive analysis of an Internet-based course constructed using a new courseware tool called moodle. Proceedings of the Higher Education Research and Development Society of Australasia (HERDSA), 2002.

ENADE. Exame Nacional de Desempenho de Estudantes. Disponível em: http://www.inep.gov.br/superior/enade/default.asp, 2010. Último acesso em 01 de fevereiro de 2010.

ENEM. Exame Nacional do Ensino Médio. Disponível em: http://www.enem.inep.gov.br/, 2010. Último acesso em 01 de fevereiro de 2010.

L. Eronen. User Centered Design of New and Novel Products: case Digital Television. Tese de doutorado, Helsinki University of Technology, 2004.

J. D. P. R. Filho e R. F. Lopes. Avaliação de aprendizagem por meio da TV Digital Interativa. Anais do VI Congresso Brasileiro de Ensino Superior a Distância (EsuD), 2009. Anais do VI Congresso Brasileiro de Ensino Superior a Distância (EsuD 2009).

M. Frantzi, N. Moumoutzis, e S. Christodoulakis. A Methodology for the Integration of SCORM with TV-Anytime for Achieving Interoperable Digital TV and e-Learning Applications. In Proceedings of the IEEE International Conference on Advanced Learning Technologies, páginas 636-638, Washington, DC, USA, 2004. IEEE Computer Society. ISBN 0-7695-2181-9.

T. French e M. Springett. Developing novel iTV applications: a user centric analysis. In J. Masthof, R. Griffiths, e L. Pemberton, editores, Proceedings of the 1st European Conference on Interactive Television: from Viewers to Actors?, páginas 29-39, 2003.

H. Fuks, M. A. Gerosa, e C. G. Barreto. Middleware de Integração entre o Ambiente AulaNet eo Ginga. SET - Congresso da Sociedade Brasileira de Engenharia de Televisão, 2007.

Futura. Canal Futura - Disponível em: http://www.futura.org.br - Último acesso em 01 de fevereiro de 2011, 2011. URL http: / / www. futura.org.br. Disponivel em: http://www.futura.org.br.

GINGA. Ginga Digital TV Middleware Specification, 2009. 
H. Hermans, J. Manderveld, e H. Vogten. Educational modelling language. W. Jochems, J. van Merrienboer, \& E.J.R. Koper, Integrated eLearning, páginas 100-111, 2003.

IBGE. Instituto Brasileiro de Geografia e Estatística. Disponível em: http://www.ibge.gov.br/, 2010. Último acesso em 01 de fevereiro de 2010.

S. Im, S. Lee, e X. Wu. Design and Implementation of SCORM Content Conversion System for DiTV. In Hybrid Information Technology, 2006. ICHIT '06. International Conference on, volume 2, páginas 679-684, Nov. 2006. doi: 10.1109/ICHIT.2006.253682.

IMS. IMS AccessForAll Meta-data Overview. Final Specification Version 1.0, IMS Global Learning Consortium, 2004. URL http://bit. Iy/9rJVMn.

IMS Specification. IMS Learner Information Package Accessibility for LIP Information Model. Final Specification Version 1.0, IMS Global Learning Consortium, 2003. URL http://bit. Iy/eY1EtD.

C. H. Jardim e A. Martelini Jr. Whiteboard: uma Ferramenta de Apoio ao Ensino e Aprendizado com Uso de Anotação Eletrônica. XVI Simpósio Brasileiro de Informática na Educação (Mostra de Software), 2005.

J. Klobas. Wikis: Tools for Information Work And Collaboration: Tools for Information Work And Collaboration (Information Professional S.). Chandos Publishing (Oxford) Ltd., May 2006. ISBN 1843341786.

R. Koper e J. Manderveld. Educational modelling language: modelling reusable, interoperable, rich and personalised units of learning. British Journal of Educational Technology, 35(5):537-551, 2004.

T. Kunert. User-Centered Interaction Design Patterns for Interactive Digital Television Applications. Springer Publishing Company, Incorporated, 1st edição, 2009. ISBN 184882274X, 9781848822740.

R. L. Lachi. Chapa: um agente de interface para ferramentas de bate papo em ambientes de ensino a distância na web. Dissertação de mestrado, Unicamp, 2003.

C. Ladim e A. M. C. Ribeiro. A elaboração de projetos, Unidade 5, SENAC - Serviço Nacional de Aprendizagem Comercial, 2000. Série Educação à Distância.

S. Lamont. Case study: Successful adoption of a user-centered design approach during the development of an interactive television application. In L. P. 
Judith Masthof, Richard Griffiths, editor, Proceedings of the 1st European Conference on Interactive Television: from Viewers to Actors?, 2003.

Lince-DC. Projeto de Reúso de Software FAPESP - Avaliação do Projeto TidiaAe e suas Aplicações. Relatório técnico, UFSCar, 2010.

D. C. Lobato e L. A. Baldochi Jr. Multimedia Instant Messenger for an eLearning Environment. II TIDIA Workshop, 2005.

L. L. Lobato, B. D. S. Monteiro, e L. B. Silva. AMADeUs-MM: Rede educacional com integração de serviços multimídia. IV ICSI - International Conference on Systems Integration, páginas 1-21, 2007.

M. R. Lopez, R. P. D. Redondo, e A. F. Vilas. Entercation: engaging viewers in education through TV. Comput. Entertain., 5(2):7+, 2007.

M. Lytras. Interactive Television and E-learning Convergence: Examining the Potential of T-learning, 2002.

F. R. Marinho. Telecurso 2000. Portal do Telecurso 2000 Disponivel em: http://www.telecurso2000.org.br, 2011. URL http://www.telecurso2000.org.br.

Ministério dos Transportes. Ministério dos Transportes. Site disponível em: http: / / www.transportes.gov.br, 2010. Último acesso em 01 de fevereiro de 2010.

B. d. S. Monteiro. Amadeus-TV: Portal Educacional na TV Digital Integrado a um Sistema de Gestão de Aprendizado. Dissertação de mestrado, Universidade Federal de Pernambuco, 2009.

B. D. S. Monteiro, T. M. Frota, F. F. Souza, e A. S. Gomes. Desenvolvimento de Objetos de Aprendizagem para TVDi. XIX Simpósio Brasileiro de Informática na Educação (SBIE), 2008.

C. Montez e V. Becker. TV Digital Interativa: conceitos, desafios e perspectivas para o Brasil. Ed. da UFSC, $2^{a}$ edição edição, 2005.

M. Moore e G. Kearley. Educação a distância - Uma visão integrada. Cengage Learning, 2008.

C. R. Moraes e L. S. Santos. Uma Ferramenta de Chat com Ajax e Spring para um Ambiente de Aprendizado Eletrônico. VII Workshop de Ferramentas e Aplicações (WFA) do Webmedia2008, 2:176-178, 2008.

S. Morris e A. Smith-Chaigneau. Interactive TV Standards: A Guide to MHP, OCAP, and JavaTV. Focal Press, 2005. 
V. G. Motti. Design Centrado no Usuário de um Ambiente de Reunião Instrumentado. USP, Janeiro 2009. Dissertação de Mestrado.

A. B. Mourão. Educação presencial mediada por tecnologia com interatividade em tempo real. Dissertação de mestrado, USP - Poli, 2010.

J. Nielsen e R. Molich. Heuristic evaluation of user interfaces. In VIII SIGCHI Conference on Human Factors in Computing Systems: Empowering People, 1990.

M. L. Nores, Y. Blanco-Fernández, e A. F. Vilas. Technologies to Support Collaborative Learning over the Multimedia Home Platform. In W. Liu, Y. Shi, e Q. Li, editores, ICWL, volume 3143 of Lecture Notes in Computer Science, páginas 83-90. Springer, 2004. ISBN 3-540-22542-0.

M. L. Nores, J. J. P. Arias, e J. G. Duque. A core of standards to support t-learning. In ICALT, páginas 13-15. IEEE Computer Society, 2006.

D. M. Pataca, J. H. de Augustinis Franco, e J. M. M. Rior. Tecnologias de Serviços Educacionais em Plataforma de TV Digital. Anais do Workshop de Informática na Escola, 2003.

J. J. Pazos-Arias, M. López-Nores, e J. García-Duque. Provision of distance learning services over Interactive Digital TV with MHP. Computers e Education, 50(3):927 - 949, 2008. ISSN 0360-1315. doi: DOI:10.1016/j.compedu. 2006.09.008.

L. Piccolo, A. Melo, e M. Baranauskas. Accessibility and interactive tv: Design recommendations for the brazilian scenario. In J. A. Cécilia Baranauskas, Philippe Palanque, editor, Human-Computer Interaction(INTERACT 2007), volume 4662 of Lecture Notes in Computer Science, páginas 361-374. Springer Berlin - Heidelberg, 2007.

M. d. G. Pimentel, C. Prazeres, H. Ribas, D. Lobato, e C. Teixeira. Documenting the pen-based interaction. In Proceedings of the 11th Brazilian Symposium on Multimedia and the Web, WebMedia '05, páginas 1-8, New York, NY, USA, 2005. ACM. doi: http://doi.acm.org/10.1145/1114223.1114232.

P. R. Polsani. Use and abuse of reusable learning objects. Journal of Digital information, 3(4):11-21, 2003.

A. Prakash, H. S. Shim, e J. H. Lee. Data Management Issues and Trade-Offs in CSCW Systems. IEEE Transactions on Knowledge and Data Engineering, 11:213-227, 1999. ISSN 1041-4347. doi: http://doi.ieeecomputersociety. org/10.1109/69.755630. 
M. Rice e N. Alm. Designing new interfaces for digital interactive television usable by older adults. Comput. Entertain., 6:6:1-6:20, May 2008. ISSN 1544-3574. doi: http://doi.acm.org/10.1145/1350843.1350849.

E. R. Rodolpho. Convergência Digital de Objetos de Aprendizagem SCORM. Dissertação de mestrado, UNESP, 2009.

M. M. Saleemi, J. Björkqvist, e J. Lilius. System architecture and interactivity model for mobile TV applications. In Proceedings of the 3rd International Conference on Digital Interactive Media in Entertainment and Arts, DIMEA '08, páginas 407-414, New York, NY, USA, 2008. ACM. ISBN 978-1-60558248-1. doi: http://doi.acm.org/10.1145/1413634.1413706.

D. Santos. Estudo de Aplicativos de TVDi para Educação a Distância. Universidade Estadual de Campinas, 2007. Tese de Mestrado em Engenharia Elétrica.

N. Sharda e A. Hanumanula. Streaming Áudio and Video in Web-Based Learning: A Comparative Study of Three Systems. In Advances in Web-Based Learning ICWL 2003, volume 2783 of Lecture Notes in Computer Science, páginas 206-217. Springer Berlin - Heidelberg, 2003.

D. Simões, E. Teixeira, e I. A. de Oliveira. Cartografias Ribeirinhas: saberes e representações sobre práticas sociais cotidianas de alfabetizandos amazônidas., 2004.

J. A. A. Simões e V. Lindemann. Editor de Hipertextos Colaborativo Integrado ao Teleduc. XVIII Simpósio Brasileiro de Informática na Educação (SBIE), 2007.

L. F. G. Soares, R. F. Rodrigues, e M. F. Moreno. Ginga-J:The Procedural Middleware for the Brazilian Digital TV System. Journal of the Brazilian Computer Society, 13, 2007a.

L. F. G. Soares, R. F. Rodrigues, e M. F. Moreno. Ginga- NCL: The declarative environment of the Brazilian digital TV system. Journal of the Brazilian Computer Society, 12(Revista no. 4), Mar. 2007b.

M. T. Tonieto. Sistema brasileiro de tv digital - sbtvd: Uma análise política e tecnológica na inclusão social. Dissertação de mestrado, Universidade Estadual do Ceará (UECE), 2006.

A. R. Trindade. Distance Educatión for Europe. Apostila, 1997. Traduzido por José Geraldo Campos Trindade. 
J. Trindade e A. R. F. de Abreu. A convergência TV-Web: motivações e modelos. Recensio - Revista de Recensões de Comunicação e Cultura, 1999.

E. Tsekleves, R. Whitham, e K. Kondo. Bringing the television experience to other media in the home: an ethnographic study. In Proceedings of the Seventh European Conference on European Interactive Television Conference, EuroITV '09, páginas 201-210, New York, NY, USA, 2009. ACM. ISBN 9781-60558-340-2. doi: http://doi.acm.org/10.1145/1542084.1542125.

D. A. Vega-Oliveros, D. S. Martins, e M. da Graça Campos Pimentel. "This conversation will be recorded": automatically generating interactive documents from captured media. In Proceedings of the 10th ACM symposium on Document engineering, DocEng '10, páginas 37-40, New York, NY, USA, 2010. ACM. ISBN 978-1-4503-0231-9. doi: http://doi.acm.org/10.1145/ 1860559.1860568.

T. Waisman. Usabilidade em Serviços Educacionais em Ambientes de TV Digital. Tese de doutorado, Universidade de São Paulo, 2006.

D. A. Wiley. Instructional use of learning objects (online version). Agency for instructional technology - US, 2001. URL http://www.reusability.org/rEaD/. Accessed August 2009. 


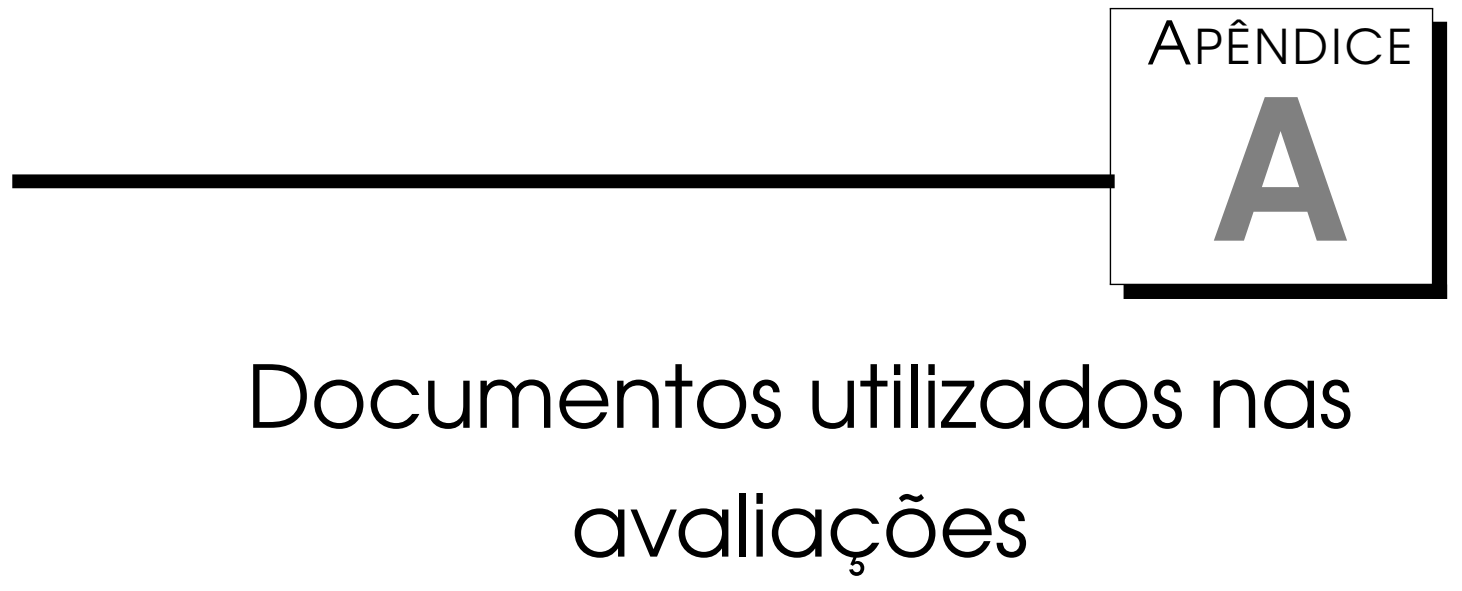

Nessa seção são apresentados os documentos utilizados nos testes desenvolvidos neste trabalho, como:

- Documento de Ciência e Autorização;

- Questionário para identificação do perfil do participante;

- Questionário de Avaliação do Sistema pelo Participante;

- Lista de Tarefas. 


\section{CIÊNCIA E AUTORIZAÇÃO}

Ref.: Teste da ferramenta DigaE

Objetivo: O objetivo dessa pesquisa é levantar dados e informações sobre a utilização da ferramenta DigaE para uma pesquisa acadêmica (dissertação de mestrado para USPSão Carlos)

Importante: O procedimento do qual você participará visa somente a testar o uso da interface da ferramenta DigaE. Não é você que está sendo testado!!

Protocolo Verbal: É solicitado que você "pense em voz alta" expondo suas dúvidas e seu entendimento quanto ao uso da ferramenta.

Informações coletadas: Vamos coletar e gravar informações sobre o modo como você utiliza a ferramenta DigaE. Nós vamos solicitar o preenchimento de questionários e você será entrevistado. $\mathrm{O}$ teste e a entrevista serão registrados em áudio e vídeo. As informações coletadas(suas e de outros participantes) servirão para recomendar melhorias na ferramenta DigaE.

Autorização para a gravação: $O$ seu uso com a ferramenta DigaE e sua entrevista serão gravadas. Assinando esse documento, você autoriza o autor a utilizar suas declarações, sua voz e sua imagem(mas não o seu nome) na dissertação do mestrado e em artigos acadêmicos, aulas, paper, apresentações em simpósios ou congressos científicos relacionados ao tema.

Liberdade para a desistência: Você pode desistir do teste no momento em que quiser.

Liberdade para perguntar: Se você tiver perguntas a fazer, pode questionar o administrador do teste agora ou a qualquer momento.

\section{Nome(por extenso):}

Data:

Assinatura: 


\section{QUESTIONÁRIO PARA IDENTIFICAÇÃO DO PERFIL DO PARTICIPANTE}

O objetivo deste questionário é colher informações sobre o perfil do participante do teste de usabilidade a ser realizado utilizando a ferramenta DigaE

As informações fornecidas são vitais para o aprimoramento do sistema.

Nas questões de marcar, favor circular a letra correspondente à resposta. A não ser que esteja indicado, deverá ser marcada somente uma resposta por questão.

Por favor, leia com atenção as questões a seguir e em caso de dúvida, solicite esclarecimento com o avaliador.

Nome:

\section{1) Informações Pessoais}

1. Qual é a sua idade?

( ) 15-- 19 anos

( ) $20-24$ anos

( ) 25-- 29 anos

( ) $30-39$ anos

( ) $40--44$ anos

( ) $45-49$ anos

( ) 50 -- 54 anos

( ) $55-59$ anos

( ) 60 anos ou mais

2. Sexo:

( ) masculino. ( ) feminino.

3. Profissão que exerce:

3.1. Atua há quanto tempo nessa área:

\section{2) Sua experiência com tecnologia}

1. Avalie sua experiência com tecnologia

( ) Nenhuma experiência

( ) Alguma experiência

( ) Experiência moderada

( ) Experiência moderadamente alta

( ) Experiência alta

2. Há quanto tempo você utiliza computador?

( ) Menos de 1 ano

( ) Entre 1 ano a 2 anos

( ) Entre 2 anos a 3 anos

( ) Entre 3 anos a 4 anos

( ) Mais de 4 anos. 
3. Em que local você utiliza o computador? (Pode-se marcar mais de uma opção)

( ) Em casa

( ) No trabalho

( ) Na escola

( ) Outros, favor especificar:

4. Em média, quantas horas por dia você utiliza o computador?

( ) Menos de 2 horas

( ) Entre 2 a 5 horas

( ) Entre 5 a 10 horas

( ) Mais de 10 horas

5. Qual sistema operacional você está acostumado a utilizar?

( ) Linux

( ) Windows

( ) Macintosh

( ) Outros:

6. Que tipo de aplicativo você está acostumado a utilizar? (Pode-se marcar mais de uma opção)

( ) Processadores de Texto (como Word)

( ) Planilhas (como Excel)

( ) Ambientes de ensino/aprendizado (como Moodle)

( ) Apresentação (como Power Point)

( ) Gestão de Projetos (como MSProject)

( ) Editoração Eletrônica (como Corel Draw)

( ) CD-ROM/Multimídia

( ) Outros:

7. Quantas horas você navega na internet?

( ) 1-3 horas

( ) 3-8 horas

( ) mais de 8 horas

8. Como você classifica a qualidade da internet que você usa?

( ) Ótima

( ) Boa

( ) Regular

( ) Ruim

Por quê? 
3. Sua relação com ambientes de ensino aprendizagem (como Moodle)

1. Você utiliza ambientes de ensino/ aprendizagem? ( )Sim ( )Não

2. Em caso positivo, que ferramentas costuma utilizar?
( ) Fórum
( ) Chat
( ) Atividades online
( ) Acesso ao material didático
( ) Vídeo Conferência
( ) Outros:

3. Avalie a facilidade de usar esse ambiente:
( ) Fácil
( ) Moderado
( ) Difícil

Comente: 
Questionário de Avaliação do Sistema pelo Participante

DigaE

O objetivo deste questionário é colher informações sobre a opinião do participante do teste que foi realizado utilizando a ferramenta DigaE.

As informações fornecidas são vitais para o aprimoramento do sistema. Nas questões de marcar, favor circular o número correspondente ao grau de concordância. A não ser que esteja indicado, deverá ser marcada somente uma resposta por questão. Por favor, leia com atenção as questões a seguir e em caso de dúvida, solicite esclarecimento com o avaliador.

\section{Favor marcar o número correspondente ao grau que você mais concorda:}

Facilidade de utilização: Difícil

Fácil

$$
\text { ( ) } 0 \text { ( ) } 1 \text { ( ) } 2 \text { ( ) } 3 \text { ( ) } 4 \text { ( ) } 5
$$

Organização das informações: Ruim

\section{Boa}
( ) 0
( ) 1 ( ) 2
( ) 3 ( ) 4 ( ) 5

Layout das telas:

\section{Confuso}

Claro
( ) 0 ( ) 1 ( ) 2
( ) 3 ( ) 4 ( ) 5

Nomenclatura utilizada nas telas (nome de comandos, títulos, campos, etc.)

\section{Confusas}

Claras
( ) 0
( ) 1 ( ) 2
( ) 3 ( ) 4 ( ) 5

Mensagens do sistema:

Confusas

Claras

( ) 0 ( ) 1 ( ) $2 \quad$ ( ) 3 ( ) 4 ( ) 5

Assimilação das informações:Difícil

Fácil
( ) 0
( ) 1 ( ) 2
( ) 3 ( ) 4 ( ) 5

No geral, a realização do teste foi:

Monótona

Interessante

( ) 0 ( ) 1 ( ) $2 \quad$ ( ) 3 ( ) 4 ( ) 5

2. Aponte situações em que você achou fácil utilizar no sistema:

3. Você acha que outras funções são necessárias neste produto? Quais? 
4. Você gostaria de ter essa ferramenta disponibilizada para o seu curso?

5. Diante do teste realizado, você acha que o programa atingiu o objetivo para o que é ajudar na comunicação entre os professores e alunos da modalidade de ensino a distância? Explique.

6. O espaço abaixo é reservado para que você exponha sua opinião e sugira melhorias no sistema. 


\section{LISTA DE TAREFAS \\ DigaE}

Agora, você dará início aos testes.

Abaixo, nós temos somente uma tarefa que deve ser executada por você utilizando o produto.

\section{Lembre-se:}

- Verbalize suas dúvidas, pois isto ajudará ao avaliador anotar a ocorrência e a razão de problemas.

- É o produto que está sendo avaliado e não você!

Você tem uma dúvida da disciplina e gostaria de grava-la usando o ambiente Diga-ae para enviar posteriormente ao professor.

Tarefa 1 : Faça login no ambiente Tidia-ae.

- No browser (Firefox), digite a página do Tidia-ae: http://localhost:8080/portal

- Entre com o usuário: aluno e senha: aluno

Tarefa 2: Escolha a disciplina SIG

Tarefa 3: Escolha a ferramenta DigaE Session

Tarefa 4: Agende uma sessão;

- Escolha a opção Agendar Sessão;

- Na opção assunto escreva: "Dúvida" e escreva o seu nome;

- Na descrição escreva: "Dúvida";

- Hora de início, selecione o dia de hoje e o horário atual mais 2 minutos;;

- Hora de fim, selecione o dia de amanhã;

- Na opção participantes, escolha Aluno;

- Em ferramentas escolha todas as opções;

- Na opção Adicionar slides, selecione o arquivo: SlideDuvida.zip que está na Pasta Documentos do computador.

- Selecione a opção Adicionar Sessão.

Tarefa 5: Quando a Sessão criada estiver liberada, entre na sessão.

Tarefa 6: Escreva uma frase no chat

Tarefa 7: Risque com a cor vermelha o slide

Tarefa 8: Grave uma mensagem rápida para o professor.

Tarefa 9: Saia da Sessão

Tarefa 10: Finalize a Sessão

Tarefa 11: Selecione a sessão e faça download para o computador da sessão criada. 
Quanto a aula do professor apresentada antes da realização das tarefas, o que você achou? Sentiu alguma dificuldade de acompanhar a aula? Gostou? Justifique.

Quais tarefas vocês sentiu dificuldade para realizar? Por quê? 